Universidad Nacional de La Plata (UNLP)

Facultad de Ciencias Médicas

Departamento de Ciencias. Fisiológicas

\title{
PARTICIPACIÓN DE LA ENDOTELINA ENDÓGENA EN EL EFECTO HIPERTROFIANTE DE LA ANGIOTENSINA II.
}

\section{TESIS DOCTORAL}

\section{María Verónica Correa}

Dra. María Cristina Camilión de Hurtado

Directora (2005-2007).

Profesora Asociada de la Cátedra de Fisiología y Física Biológica

Facultad de Ciencias Médicas, UNLP.

Investigadora Independiente (CONICET).

\section{Dr. Horacio Eugenio Cingolani}

Director (2007-2008).

Profesor Consulto de la Cátedra de Fisiología y Física Biológica

Facultad de Ciencias Médicas, UNLP.

Investigador Superior (CONICET).

Dra. Irene Lucía Ennis

Co-directora (2007-2008).

Jefe de T. P. de la Cátedra de Fisiología y Física Biológica

Facultad de Ciencias Médicas, UNLP.

Investigadora Independiente (CONICET).

Centro de Investigaciones Cardiovasculares, Facultad de Ciencias Médicas, UNLP. 


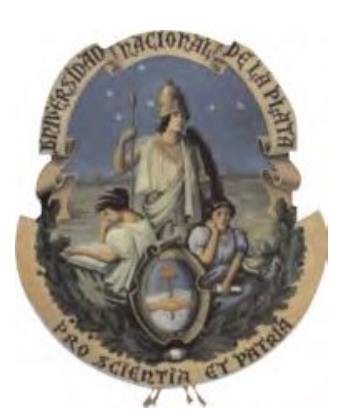

Universidad Nacional de La Plata (UNLP)

Facultad de Ciencias Médicas

Departamento de Ciencias Fisiológicas

\title{
PARTICIPACIÓN DE LA ENDOTELINA ENDÓGENA EN EL EFECTO HIPERTROFIANTE DE LA ANGIOTENSINA II.
}

\author{
TESIS DOCTORAL
}

María Verónica Correa

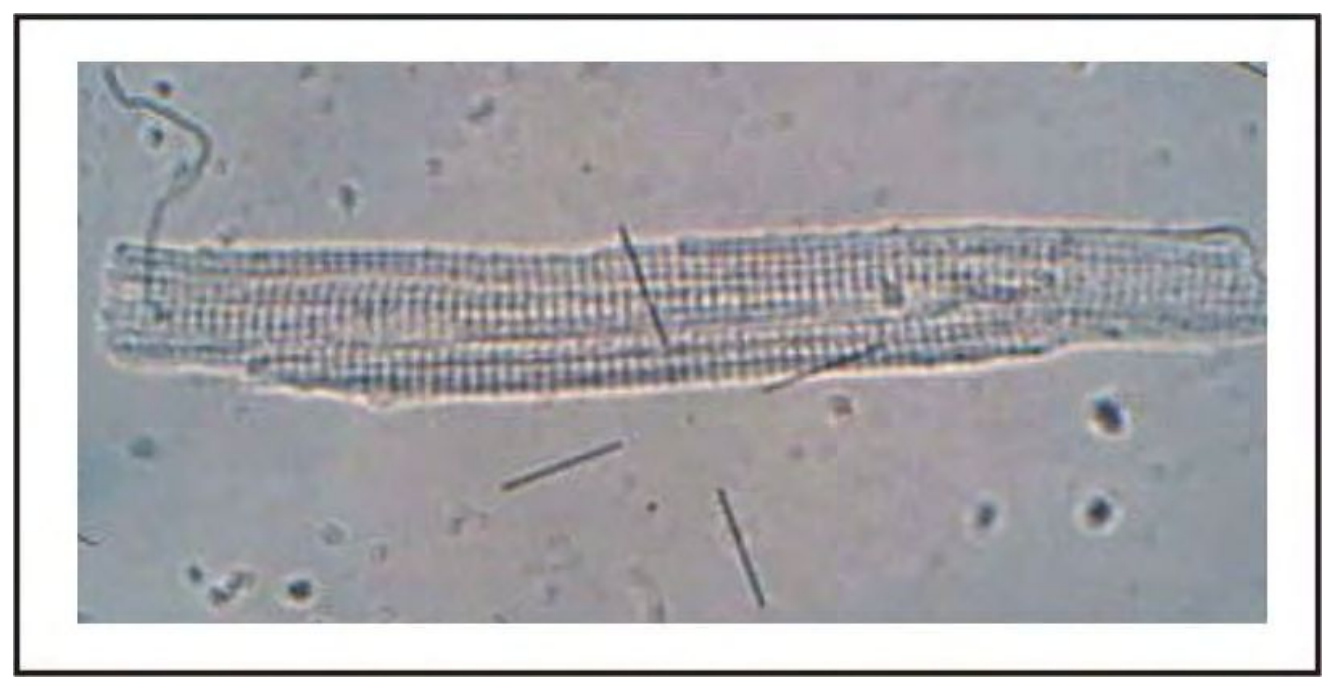

Centro de Investigaciones Cardiovasculares, CCT-La Plata, CONICET. 
Dedico este trabajo de Tesis Doctoral a mi abuela Laura a mi tía Elba a mi amor Claudio 
Agradecimientos institucionales:

A la Universidad Nacional de La Plata institución en la cual transcurrió toda mi formación escolar, media y superior. Mi agradecimiento y en homenaje a ella transcribo la Oración a la Bandera escrita por su fundador Joaquín Víctor González y que decía todos los días en el patio de la "Anexa" desde 1982 hasta 1987, año en que egresé de la misma.

Bandera de la Patria, celeste y blanca, símbolo de la unión y la fuerza con que nuestros padres nos dieron independencia y libertad; guía de la victoria en la guerra y del trabajo y la cultura en la paz.

Vínculo sagrado e indisoluble entre las generaciones pasadas, presentes y futuras.

Juremos defenderla hasta morir antes que verla humillada.

Que flote con honor y gloria al frente de nuestras fortalezas, ejércitos y buques y en todo tiempo y lugar de la tierra donde ellos la condujeren.

Que a su sombra la Nación Argentina acreciente su grandeza por siglos y siglos y sea para todos los hombres mensajera de libertad, signo de civilización y garantía de justicia.

A la Facultad de Ciencias Naturales y Museo de la UNLP por haber logrado que mi natural curiosidad por la vida, sus formas y su expresión tuvieran un marco académico donde encuadrarse.

A la Comisión de Investigaciones Científicas de la Provincia de Buenos Aires por haberme otorgado la beca de entrenamiento que me permitió dar los primeros pasos en el campo científico.

A la Agencia Nacional de Promoción Científica y Tecnológica que mediante un Proyecto de Investigación Científica y Tecnológica me permitió iniciar este trabajo de Tesis Doctoral.

A la Facultad de Ciencias Médicas de la UNLP por otorgarme el espacio físico donde desarrollar este trabajo de Tesis Doctoral y otorgarme un cargo de Ayudante Diplomado para desempeñar la docencia universitaria. 
Al Consejo Nacional de Investigaciones Científicas y Técnicas por otorgarme la Beca de post-grado tipo II que sirvió para finalizar este trabajo de Tesis Doctoral.

Agradecimientos profesionales:

A la Dra. Camilión por haberme dirigido durante el desarrollo de esta tesis, por su compromiso para llevar a cabo este trabajo.

Al Dr. Cingolani por aceptarme como integrante de sus proyectos de investigación y como su tesista doctoral. También por escucharme y orientarme cada vez que lo necesité.

A la Dra. Ennis por aceptar dirigirme en la beca y en la tesis. También por corregir todo lo necesario para que mi trabajo fuera lo mejor posible.

A la Dra. Mattiazzi por permitir que desarrolle mi trabajo de tesis en este Centro y por su buena predisposición cada vez que necesité hablar con ella ya sea por razones laborales o particulares.

A la Dra. Salas por su constante apoyo, paciencia y consejos para mejorar mi trabajo. Por ser una excelente persona y no dudar a la hora de ayudar a quien lo necesite.

Al Dr. Rinaldi por su buena predisposición para ayudarme y por construir los electrodos que se utilizaron para estimular los miocitos.

A Alex (Dr, Hielo) por aceptarme y colaborar en los experimentos en el lonoptix.

A Clau, Ceci Álvarez y Chichita por enseñarme a procesar las muestras para incorporación.

A Alfredo y Miriam por su ayuda con la determinación de DNA.

A Lalito, Gus, Martín, Ale y Vero por la paciencia y colaboración con los aislamientos de miocitos. 
A Mariela por su aporte en la determinación del $A R N_{m}$ de ANF y Carolina por enseñarme la técnica de Western blot.

A Emmanuel y Leandro por su colaboración imprescindible con el manejo de los animales.

A los integrantes del Centro de Investigaciones Cardiovasculares por estar siempre y con la mejor predisposición, Leticia, Roque, Eduardo, Gustavo, Charly, Matilde, Romina, Cecilia Mundiña, Martín Vila, Andrés, Julieta, Juliana, Susana, Luciana, Omar, Carolina, Mariela, Celeste, Magdalena, Alicia Rodríguez y Edith.

Agradecimientos personales:

A mi directora Cristina: como te fuiste pronto no llegué a decirte muchas cosas, tal vez algunas de ellas no eran importantes. Me faltó agradecerte la oportunidad que me diste al otorgarme la beca de Agencia que hizo que empezara con vos el doctorado.

No siempre estuvimos de acuerdo en todo pero podíamos lograr entendernos. Y también sé que hiciste por mí y para mí muchas cosas que no sólo tenían que ver con el trabajo en el laboratorio. Gracias Cristina por todo lo que me enseñaste, ojalá haya sido buena alumna más que nada porque tuve una excelente maestra. Esta frase es para vos y resume lo que creo y siento por vos: "Hay hombres que luchan un día y son buenos. Hay otros que luchan un año y son mejores. Hay quienes luchan muchos años y son muy buenos. Pero hay los que luchan toda la vida: esos son los imprescindibles." Bertolt Brecht. GRACIAS CRISTINA.

A Claudio por su incondicionalidad, infinita paciencia y buen humor que hizo más llevaderos los días en que finalizar este trabajo parecía imposible. Por elegirnos todos los días y por apoyarme y aconsejarme en cualquier decisión que tuviera que tomar. Por los proyectos que tenemos y porque sin vos nada sería posible ni tendría sentido. 
A María José por orientarme con respecto a las decisiones que se deben tomar en este ámbito para lograr que el desarrollo de este trabajo sea lo más armonioso posible.

A Nora por su amistad y gran profesionalismo que me ayudaron a poder transitar el camino que había elegido.

A Lalo, Martín y Gus mis compañeros de laboratorio: por soportar desde las condiciones de calor (debido a los aislamientos) hasta mi enojo por los aislamientos fallidos, las charlas, los consejos, escucharme con paciencia y siempre ayudarme con lo que pudieran.

A Marga, por escucharme, tenerme paciencia y brindarme su amistad. Por querer ayudarme y ser fuente de conocimiento académico y de sabiduría en lo que respecta a la vida.

A Moniquín por enseñarme la técnica de aislamiento, los mates, los auxilios, y la buena onda.

A Vene, Mary y Tony por aceptarme como soy (con todo lo que eso significa y que no es poco) y considerarme parte de la familia, gracias por su apoyo y cariño.

A mis compañeros de facultad y amigos: Anei, Anita, Victorín, Mari, Jime, Sole y Eduardo.

A mis amigas de siempre Tati, Ner, Ro y Sara porque el tiempo no alteró nuestros sentimientos de compañerismo y amistad.

Dedico este trabajo de Tesis Doctoral a todos los que como yo todos los días elegimos seguir creyendo que existe un futuro mejor y que podemos construirlo porque todos formamos parte de ello y que se puede doblegar la voluntad de aquellos que por ineptos e incompetentes desearían doblegar la de uno. 



\section{ÍNDICE}

INTRODUCCIÓN

Definición de Hipertrofia Cardíaca

Tipos de Hipertrofia Cardíaca

Mecanismos celulares de la respuesta hipertrofica

Angiotensina II

8

Endotelina

Las Especies Reactivas derivadas del Oxígeno:

El Intercambiador $\mathrm{Na}+/ \mathrm{H}+$

PROPÓSITO DE TRABAJO:

Propósitos particulares

Aislamiento y cultivo de miocitos cardíacos

Determinación del efecto hipertrofiante de Ang II y ET-1

Incorporación de fenilalanina marcada con tritio $\mathrm{H}^{3} / \mathrm{DNA}$

Tamaño celular: largo, ancho y área celulares

Expresión del $\mathrm{ARN}_{\mathrm{m}}$ de ANF como gen marcador de hipertrofia

Determinación del papel de las ERO en el desarrollo de hipertrofia por Ang II

Determinación de la participación de las MAPK relacionada con la 
producción de HC.

Análisis estadístico

RESULTADOS

Efecto hipertrofiante de Ang II

Efecto hipertrofiante de Ang II mediado por ET-1

Efecto hipertrofiante de ET-1

Participación del NHE-1 en el efecto hipertrofiante de ET-1

Participación del NHE-1 en la expresión del $A R N_{m}$ de ANF mediada por

ET-1

Participación de ET-1 en la producción de ERO estimulada por Ang II

Participación de las ERO en el efecto hipertrofiante de ET-1

Participación de las MAPK en el efecto hipertrofiante de ET-1

DISCUSIÓN

Liberación de ET-1 por Ang II

63

Formación de ERO por Ang II

Las NADPH Oxidasas como fuente de ERO

La mitocondria como fuente de ERO

Activación de quinasas por ERO

NHE-1 e Hipertrofia Cardíaca 
CONCLUSIÓN FINAL

BIBLIOGRAFÍA 


\section{PARTICIPACION DE LA ENDOTELINA ENDOGENA EN EL EFECTO HIPERTROFIANTE DE LA ANGIOTENSINA II.}

\section{INTRODUCCIÓN:}

El corazón es un órgano cuya principal función es la de propulsar la sangre a través del sistema circulatorio. Para cumplir con esta función, el tejido cardíaco cuenta con células musculares de tipo estriado denominadas miocitos cardíacos, los cuales son capaces de desarrollar fuerza contráctil organizada. Además de dichos miocitos, el corazón también posee otros tipos celulares, entre los que se encuentran células endoteliales endocárdicas y vasculares, musculares lisas, fibroblastos, macrófagos, células especializadas en la conducción de estímulos eléctricos y células con función endócrina (1).

Resulta muy interesante el hecho de que aunque los miocitos posiblemente pierden la capacidad de proliferar tempranamente luego del nacimiento por ser células altamente diferenciadas $(2,3)$, son aún capaces de responder a estímulos que promueven su crecimiento $(4,5)$ como sucede en diversas condiciones fisiológicas y/o patológicas. Entre estos estímulos se encuentra el estiramiento del miocardio producido por el aumento de la carga hemodinámica y/o la liberación de factores humorales circulantes o provenientes de las mismas células cardíacas (mecanismos autocrinos y/o paracrinos) que a través de la activación de señales intracelulares, promueven el aumento del tamaño de los cardiomiocitos a expensas de la formación 
o agregado de sarcómeros. De esta manera los miocitos cardíacos crecen en largo y/o en ancho dando origen a la hipertrofia cardíaca (HC).

\section{Definición de Hipertrofia Cardíaca}

El concepto de $\mathrm{HC}$ se basó tradicionalmente en el aumento de peso del corazón determinado principalmente por el mayor tamaño de los miocitos, como ya fue señalado. Las células musculares cardíacas si bien representan sólo aproximadamente el $30 \%$ del número total de las células del miocardio, dado su gran tamaño constituyen aproximadamente el $76 \%$ del volumen del órgano y por ello su crecimiento impacta significativamente sobre el peso final del corazón. Sin embargo recientemente Merkle y col. (6) que trabajaron con un modelo en ratón que sobreexpresa la proteína caspasa l (cisteína-proteasa involucrada en los mecanismos de apoptosis) señalaron que se evidenció HC y fibrosis en el miocardio sin aumento del peso del corazón. Esta nueva evidencia sugiere la posibilidad de reubicar la definición de $\mathrm{HC}$ a nivel del tamaño del miocito, no necesariamente acompañada por aumento de peso del órgano si se tiene en cuenta que el determinante de la respuesta hipertrófica puede generar simultáneamente apoptosis disminuyendo entonces el número total de miocitos con su repercusión en el peso final del corazón.

\section{$\underline{\text { Tipos de Hipertrofia Cardíaca }}$}

La HC podría interpretarse "a priori” como una respuesta adaptativa del miocardio frente a la situación que la origina. Al aumentar el espesor de la pared ventricular como consecuencia de la $\mathrm{HC}$, se favorecería la normalización del estrés al que está sometido el ventrículo ante una sobrecarga hemodinámica, de acuerdo a lo enunciado por la Ley de Laplace (Tensión: Presión x Radio/2Espesor). En 
determinadas situaciones como durante el crecimiento, el embarazo o la práctica de actividad física intensa, la respuesta a la sobrecarga hemodinámica se caracteriza por aumento del tamaño de los miocitos con incremento proporcional de los elementos estructurales del miocardio y con función contráctil conservada o incluso aumentada. Este tipo de respuesta se denomina HC fisiológica y cumple realmente una función de adaptación.

Por el contrario, puede suceder que la HC se acompañe de aumento de la fibrosis intersticial, mayor incidencia de apoptosis, disminución de la densidad capilar y reprogramación de la expresión génica con inducción de genes fetales y represión de los genes que codifican las respectivas isoformas del adulto (5,7-11). Estas alteraciones en la estructura del miocardio se asocian con deterioro de la función ventricular evolucionando habitualmente hacia la insuficiencia cardíaca, razón por la que a este tipo de HC se la define como HC patológica.

Son numerosas las evidencias que sustentan que la HC patológica no es necesaria para la compensación funcional frente a una situación de sobrecarga hemodinámica a pesar de prevenir o atenuar el aumento del estrés parietal. La inhibición de su desarrollo en distintas situaciones de sobrecarga hemodinámica experimental no produce deterioro en la función cardíaca (12-14). Del mismo modo, la inducción de su regresión conlleva una reducción del riesgo cardiovascular independientemente del tratamiento por el que se logre $(15,16)$.

Al analizar la respuesta hipertrófica en el corazón entero es importante tener en cuenta no solamente la modificación de su peso sino la relación del espesor parietal con el diámetro de la cavidad, principalmente al estudiar la hipertrofia ventricular izquierda, porque a partir de este análisis se encontrarán diferentes modificaciones 
de la geometría de esa cavidad. Según el estímulo que origine la $\mathrm{HC}$ la respuesta generará un incremento proporcionalmente mayor del espesor parietal en relación al diámetro de la cavidad o de éste último en relación al espesor de la pared, dando origen a los fenotipos de HC concéntrica o excéntrica respectivamente (17). La HC concéntrica se caracteriza por un aumento del espesor de la pared ventricular, con poco o ningún grado de dilatación de la cavidad. La incorporación de sarcómeros es predominantemente en paralelo con el consecuente crecimiento en ancho del miocito. Esta forma de HC está generalmente asociada a estímulos que producen sobrecarga crónica de presión (por ejemplo, hipertensión arterial o estenosis aórtica). La HC excéntrica se caracteriza por un incremento menor del espesor de la pared ventricular y aumento en el volumen de la cavidad debido al agregado de sarcómeros en serie que induce un aumento preferentemente en la longitud del miocito. Se encuentra frecuentemente asociada a la sobrecarga de volumen como ocurre cuando hay valvulopatías regurgitantes. La aparición de un infarto de miocardio genera una situación de sobrecarga hemodinámica más compleja determinando una combinación de sobrecarga de volumen y de presión que desencadena un aumento del espesor de la pared ventricular en la región no infartada con dilatación de la cavidad $(18,19)$. El aumento de la fibrosis, como resultado de una mayor síntesis de colágeno por los fibroblastos, está presente en los tres patrones de $\mathrm{HC}$ patológica.

En la figura 1 se encuentran representados los diferentes fenotipos que se pueden encontrar en la HC. 


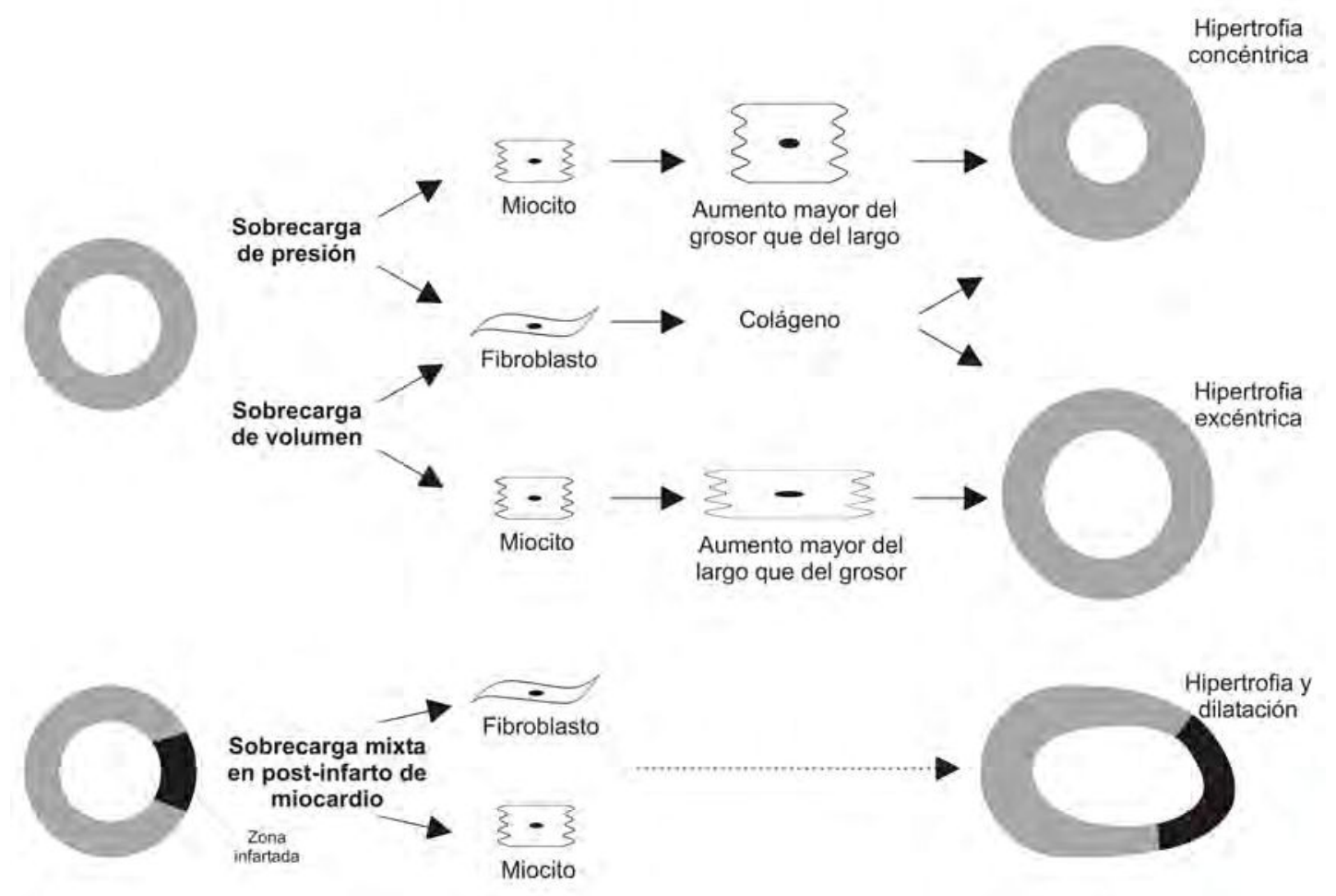

Figura 1: Esquematización de los patrones principales de HC según el tipo de sobrecarga hemodinámica que las origina. En la sobrecarga de presión el tamaño de los miocitos aumenta predominantemente en el grosor, dando lugar a la HC concéntrica. Se observa en un esquema de corte transversal del ventrículo izquierdo, que el crecimiento de la pared del miocardio es predominantemente hacia el centro de la cavidad. En la sobrecarga de volumen el tamaño de los miocitos aumenta predominantemente en largo, originando la $\mathrm{HC}$ excéntrica. En el post-infarto de miocardio existe sobrecarga de presión y de volumen sobre las zonas no infartadas y el resultado es una combinación de $\mathrm{HC}$ concéntrica y excéntrica.

La respuesta hipertrófica o remodelamiento hipertrófico, es el resultado de la estimulación de múltiples vías de señalización intracelular que alteran la transcripción génica $(20,21)$ promoviendo modificaciones a nivel celular y molecular que se manifiestan mediante una serie de cambios morfológicos y funcionales. En los últimos años, el estudio del proceso de desarrollo de HC patológica ha sido motivo de numerosos trabajos de investigación, a pesar de lo cual aún no se lo comprende plenamente $(22,23)$. Se sabe que la respuesta hipertrófica involucra la alteración de genes que codifican proteínas involucradas en la homeostasis del 
calcio $\left(\mathrm{Ca}^{+2}\right)$ y del sodio $\left(\mathrm{Na}^{+}\right)$así como el aumento de los niveles de óxido nítrico (NO) y péptidos natriuréticos (24-27). Además, diversos estudios han demostrado que una de las características más notorias de la HC es la reexpresión de genes fetales (factor natriurético atrial (ANF), cadena pesada de la miosina $\beta$ y alfa-actina esquelética), los cuales constituyen de este modo marcadores consistentes de $\mathrm{HC}$ (28).

$\underline{\text { Mecanismos celulares de la respuesta hipertrófica }}$

Una amplia variedad de factores, algunos de los cuales son producidos por el corazón mismo, han sido implicados en la patogénesis de la HC (29). Péptidos vasoactivos como Angiotensina II (Ang II) o Endotelina (ET) han sido involucrados en la respuesta hipertrófica a la sobrecarga hemodinámica mediante mecanismos autocrinos/paracrinos (30-33). Resulta interesante que un reconocido blanco de acción de estos péptidos es el intercambiador $\mathrm{Na}^{+} / \mathrm{H}^{+}$(NHE) $(34,35)$, mecanismo celular alcalinizante que ha sido reiteradamente vinculado al desarrollo de $\mathrm{HC}$ independientemente de su etiología (36-40). En tal sentido, De la Sierra y colaboradores (41) encontraron que el NHE estaba hiperactivo en eritrocitos de pacientes con hipertrofia ventricular izquierda y que la hiperactividad se correlacionaba muy bien con el nivel de $\mathrm{HC}$ y no así con los valores de presión arterial. Por otra parte se ha demostrado que los corazones hipertróficos de ratas espontáneamente hipertensas (SHR) tienen aumentada la actividad del NHE $(42,43)$; en concordancia con los resultados de De la Sierra en estos animales es 
posible corregir la $\mathrm{HC}$ por inhibición del NHE sin reducir significativamente los valores de presión arterial $(44,45)$.

Un conocido segundo mensajero en la transducción de una extensa cantidad de señales intracelulares involucradas en el crecimiento celular es el $\mathrm{Ca}^{+2}$ intracelular $\left(\mathrm{Ca}^{+2}{ }_{\mathrm{i}}\right)$. Zhu y colaboradores (46) demostraron que la inducción de HC por la isoforma 1 de la ET (ET-1) en cardiomiocitos requiere la activación de rutas dependientes de $\mathrm{Ca}^{+2}$-calmodulina quinasa II (CaMKII) y de la fosfatasa calcineurina. A pesar de que el aumento de la concentración $\mathrm{Ca}^{+2}$ intracelular $\left(\left[\mathrm{Ca}^{+2}\right]_{i}\right)$ ha sido propuesto como mediador de los efectos hipertróficos de ET-1 (46), los trabajos realizados con el fin de demostrar esto no describen con claridad las posibles causas de dicho aumento.

De lo expresado anteriormente se desprende que a pesar de que las causas del desarrollo de $\mathrm{HC}$ han sido motivo de un gran número de trabajos de investigación, todavía queda mucho camino por recorrer en cuanto a la identificación de las vías de señalización involucradas. El esclarecimiento de las señales intracelulares que provocan la $\mathrm{HC}$ podría resultar de fundamental importancia para el desarrollo futuro de estrategias preventivas y/o terapéuticas destinadas a su control.

Angiotensina II

La Ang II es un octapéptido que, además de poseer un potente efecto vasoconstrictor, produce numerosos efectos sobre otros tejidos. En el miocardio produce aumento del inotropismo y de la frecuencia de contracción, estimulación de la síntesis proteica e hipertrofia de los miocitos, estimulación de la proliferación de 
fibroblastos y producción de colágeno (47). Si bien originalmente el sistema reninaangiotensina (SRA) fue descrito como un sistema hormonal general (48), actualmente se conoce la existencia de SRA locales capaces de ejercer una función modulatoria en diversos tejidos incluido el miocardio $(47,49)$. Al respecto cabe señalar que varios de los componentes del SRA fueron encontrados en numerosos tipos de tejidos y la síntesis local de Ang II se ha demostrado en órganos aislados $(47,49,50)$.

La forma clásica descripta en la década de 1960 para la secreción de Ang II propone que en respuesta a la disminución de la presión arterial o a la disminución del $\mathrm{Na}^{+}$ extracelular $\left(\mathrm{Na}^{+}\right)$a nivel sistémico, las células yuxtaglomerulares renales liberan renina al plasma (51). Esta última es una proteasa que ejerce su acción sobre el angiotensinógeno, un glucopolipéptido circulante de 14 aminoácidos (aa) perteneciente a la familia de las a-2-gobulinas y sintetizado principalmente en el hígado generando un producto de 10 aa, conocido como angiotensina I (Ang I). Luego, la enzima convertidora de angiotensina (ECA), presente principalmente en pulmón, cliva la Ang I produciendo el octapéptido Ang II. Ésta tiene una vida media muy breve (aproximadamente una hora) ya que es degradada por distintas peptidasas presentes en los tejidos dando como producto la angiotensina III que posee menor actividad (524). En el músculo cardíaco se ha comprobado la expresión de $A R N$ mensajero $\left(A R N_{m}\right)$ del angiotensinógeno, de la ECA y de receptores de Ang II $(50,53)$ sustentando la posibilidad de la síntesis local de Ang II. La figura 2 esquematiza sintéticamente las etapas de la generación y degradación de Ang II. En concordancia con esto, las concentraciones de Ang I y Ang II medidas en el intersticio miocárdico se hallan en el rango nanomolar, valores que superan en 
aproximadamente 100 veces la concentración plasmática de ambos péptidos (54). Asimismo, trabajos recientes han demostrado la participación del SRA tisular en el aumento del inotropismo y de la $\mathrm{HC}$, entre otros efectos observados al estirar el miocardio (55-58).

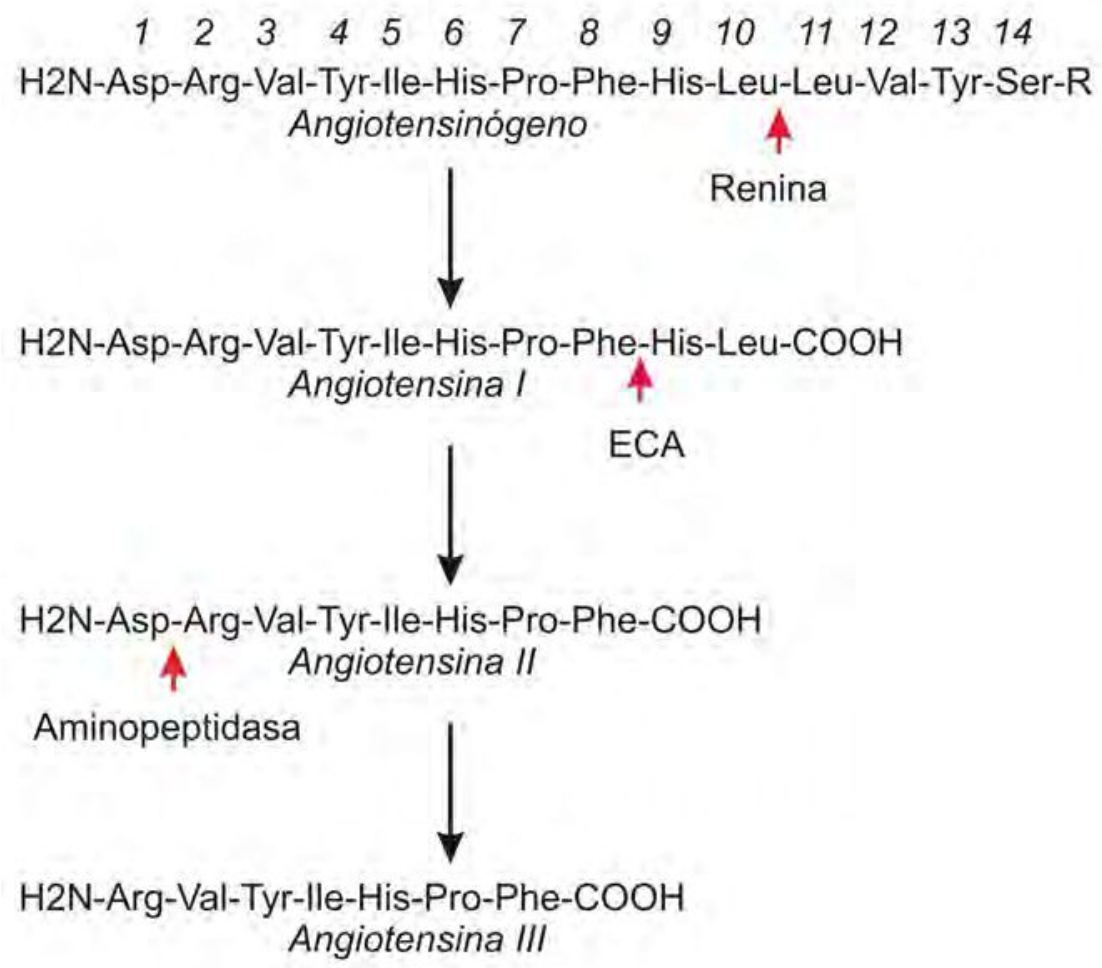

Figura 2: Representación del SRA. Etapas de generación y degradación de Ang II.

Mediante estudios de unión de ligando ("binding") se han encontrado dos tipos de receptores de Ang II en diferentes tejidos: el tipo $1\left(\mathrm{AT}_{1}\right)$ sensible al bloqueo con losartán (Los) y el tipo 2 (AT2) que es inhibido por PD123319 (59-61). Ambos tipos de receptores se expresan en el corazón humano y de otras especies como gato, rata, conejo y mono $(62,63)$. La distribución de los subtipos de receptores cambia según el tejido y la especie que se considere, variando las proporciones relativas de ambos (64-67). 
Los receptores $A T_{1}$ y $A T_{2}$ tienen acciones opuestas en lo que respecta al crecimiento celular (68-70). Ha sido demostrado que la estimulación de los $\mathrm{AT}_{2}$ produce efectos antiproliferativos, proapoptóticos, de diferenciación celular y de disminución de la matriz extracelular en el corazón (71.72).También se evidenció aumento en la producción de NO y disminución de la frecuencia cardiaca $(73,74)$. Los receptores $A T_{1}$, en cambio, favorecen el efecto inotrópico positivo (EIP), la vasoconstricción, el aumento de la expresión génica, de la síntesis proteica, de la fibrosis y del remodelamiento cardíaco que conducen a la $\mathrm{HC}(59,75-78)$, constituyendo el inicio de la vía de señalización que se estudia con mayor detalle en este trabajo.

El receptor $\mathrm{AT}_{1}$ está compuesto por 359 aa, contiene 7 dominios transmembrana y tiene un $30 \%$ de homología con el receptor $\mathrm{AT}_{2}$. Ambos receptores pertenecen a la familia de receptores acoplados a proteínas regulatorias G (RAPG) la cual recibe este nombre por la capacidad de fijar nucleótidos de guanina, específicamente a la proteína $G$ de tipo $q\left(G_{q}\right)(79)$. Esta proteína $G$ es un complejo proteico compuesto por 3 subunidades, alfa $(\alpha)$, beta $(\beta)$ y gama $(\gamma)$ que intervienen en múltiples caminos de señalización intracelulares. La subunidad a tiene el sitio de unión para los nucleótidos de guanina y la actividad GTPasa y es la determinante del tipo de efecto asociado al receptor (da la denominación al tipo de proteína G). Durante el estado inactivo, una molécula de GDP se encuentra unida al sitio de unión a nucleótidos (80). La unión de Ang II con el receptor $A T_{1}$ determina que la subunidad $\alpha_{q}$ sufra un cambio conformacional que causa el reemplazo de GDP por GTP y la disociación del trímero (ver mecanismo de acción general en figura 3). Esta subunidad $\alpha_{q}$ activa la isoforma $\beta$ de la fosfolipasa $C(P L C \beta)$. 


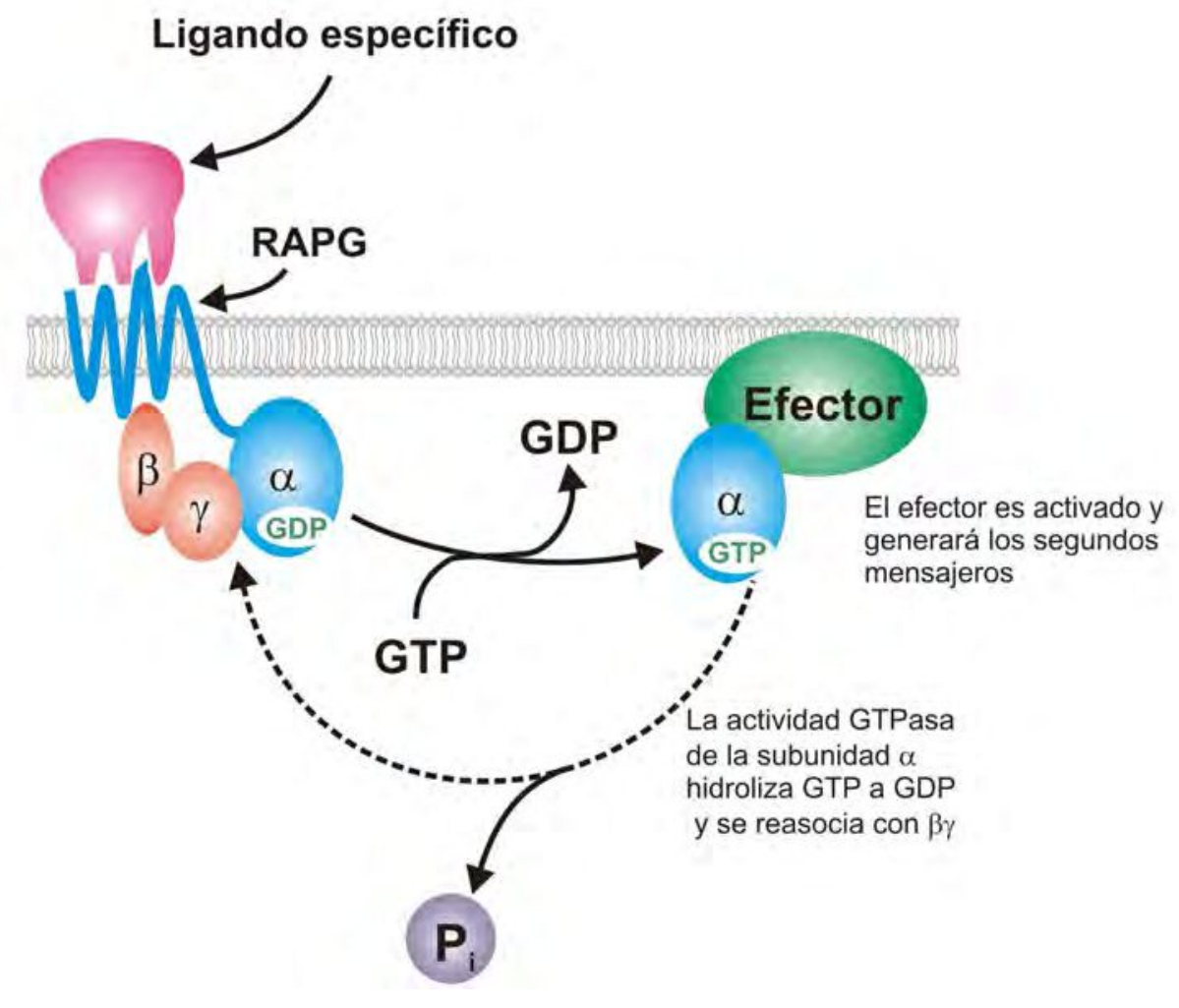

Figura 3: Mecanismo general de acción de los receptores asociados a proteína G. La unión del ligando al receptor activa la proteína G, lo cual promueve el intercambio de GDP por GTP en la subunidad Ga y esto provoca la disociación de ambas subunidades del receptor en el dímero $\beta \gamma$ y la subunidad $\alpha$. La subunidad $\alpha$ activa, se traslada hasta interaccionar con el efector blanco, el cual amplifica la señal a través de la síntesis de segundos mensajeros.

La PLC $\beta$ es una enzima que hidroliza fosfatidil inositol-4,5-bifosfato (PIP2) para dar inositol-1,4,5-trifosfato $\left(\mathrm{IP}_{3}\right)$ y diacilglicerol (DAG). El IP 3 puede inducir la liberación de $\mathrm{Ca}^{+2}$ al citosol desde depósitos intracelulares $(81,82)$ como el retículo sarcoplásmico (RS) o desde la envoltura nuclear (83). EI DAG, que permanece unido a la membrana, es un activador de proteína quinasa $C(P K C)$ de la cual existen varias isoformas, algunas dependientes de $\mathrm{Ca}^{+2}(\alpha, \beta 1, \beta 2, \mathrm{y})$ y otras independientes de ese catión $(\delta, \varepsilon, \lambda / \zeta)(84,85)$. La PKC a su vez activa a las quinasas de proteínas activadas por mitógenos (MAPKs) a través de la quinasa Raf. La activación de las 
MAPKs puede producirse a través de Raf por una vía independiente de Gaq que involucra a quinasas de tirosina. La MAPK ERK1/2 fosforila a la quinasa p90RSK, y esta última activa por fosforilación al NHE (86). De esta manera se promueve la entrada de $\mathrm{Ca}^{2+}$ a través de la ruta NHE/ intercambiador $\mathrm{Na}^{+} / \mathrm{Ca}^{+2}$ (NCX). El aumento de la concentración de $\mathrm{Ca}^{2+}{ }_{i}\left(\left[\mathrm{Ca}^{2+}\right]_{i}\right)$ sería el responsable de la activación de fosfatasas y/o quinasas que determinan el aumento de la transcripción y de la síntesis proteica y por ende el desarrollo de HC (ver figura 4) (87).

De esta manera, tanto PKC como $\mathrm{IP}_{3}$ median muchos de los efectos de Ang II actuando como segundos mensajeros a diferentes niveles intracelulares. PKC puede activar, entre otras vías, quinasas tales como JAK-STAT (Janus kinase-signal tranducers and activators of transcription) (88-90).

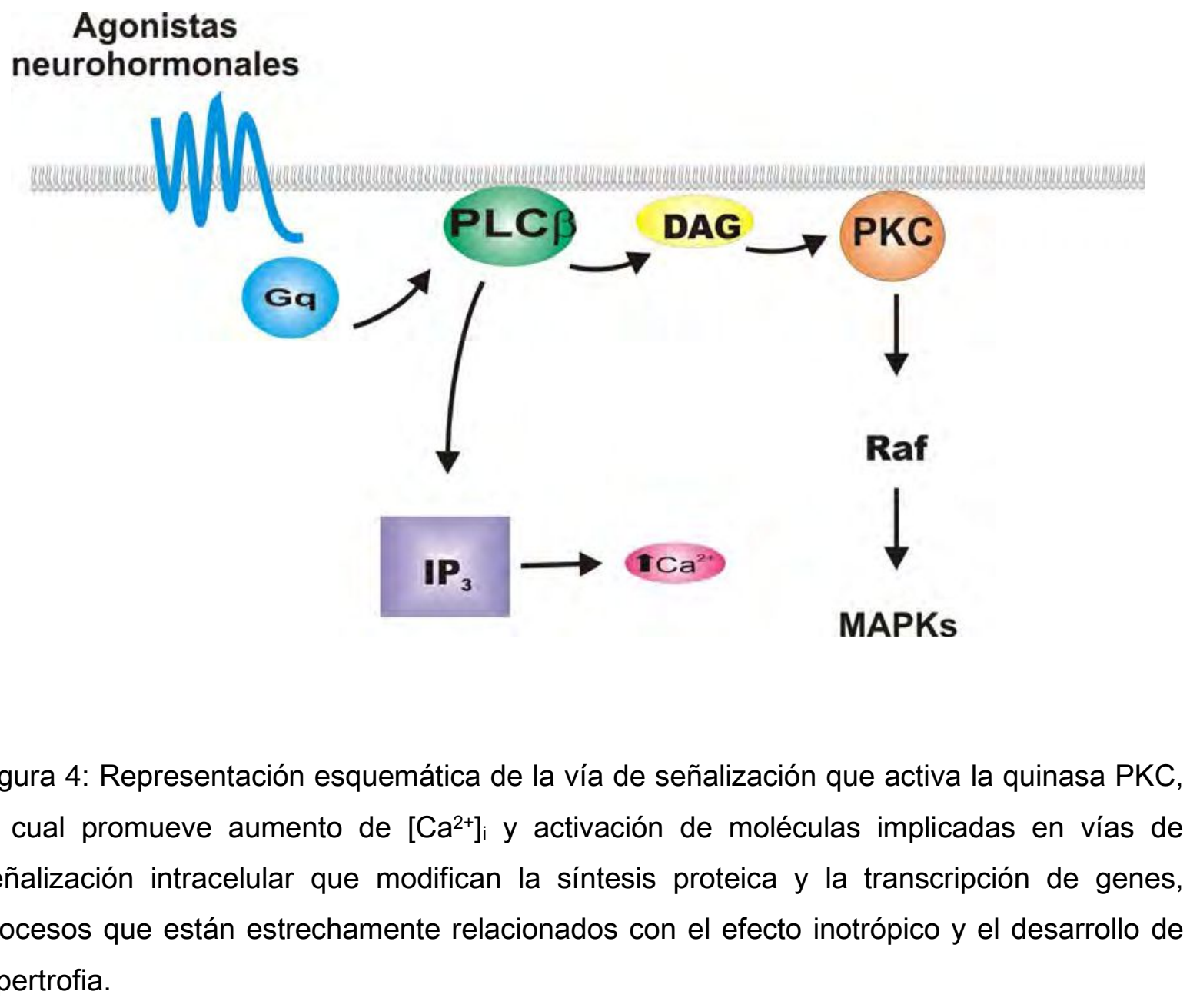


Se ha demostrado recientemente que la Ang II puede también activar a la fosfolipasa A2 (91) y la producción de NO a través de los receptores AT2 (74).

Los mecanismos desencadenados por estimulación de los receptores $A_{2}$ son menos conocidos, pero existen evidencias de que a través de la activación de tirosina fosfatasas, ejercerían sus efectos antihipertróficos por oponerse a los efectos de las quinasas antes mencionadas $(70,71,92)$.

Endotelina

La ET es un potente péptido vasoconstrictor aislado inicialmente de cultivos de células endoteliales de aorta porcina (93). Se conocen al menos 3 isoformas derivadas de genes diferentes, que dan como resultado final péptidos de 21 aa denominados ET-1, ET-2 y ET-3 (94). Las endotelinas derivan de preproendotelinas (de aproximadamente 212 aa) las cuales son clivadas por una proteasa del tipo de la furina $(95,96)$ dando las respectivas ET-grandes (o "big-ETs") de 38 aa. Luego son nuevamente clivadas por una metaloproteasa llamada enzima convertidora de endotelina (ECE) para dar los polipéptidos de 21 aa. Respecto de la ECE, se conocen tres isoenzimas: ECE-1, ECE-2 y ECE-3. ECE-1 es una proteína de membrana derivada de un solo gen que da 4 isoformas posibles (ECE-1a, ECE-1b, ECE-1c y ECE-1d) $(97,98)$. Las 3 isoenzimas se expresan en distintas proporciones según el tejido. Tanto ECE-1 como ECE-2 son más específicas para big-ET1 que ECE-3. ECE-2 es activada preferentemente a bajos $\mathrm{pH}$ y es la única que no se 
encuentra en la membrana celular (99). ECE-3 fue descripta en microsomas de iris bovino siendo muy específica para big-ET3 (100) (figura 5).

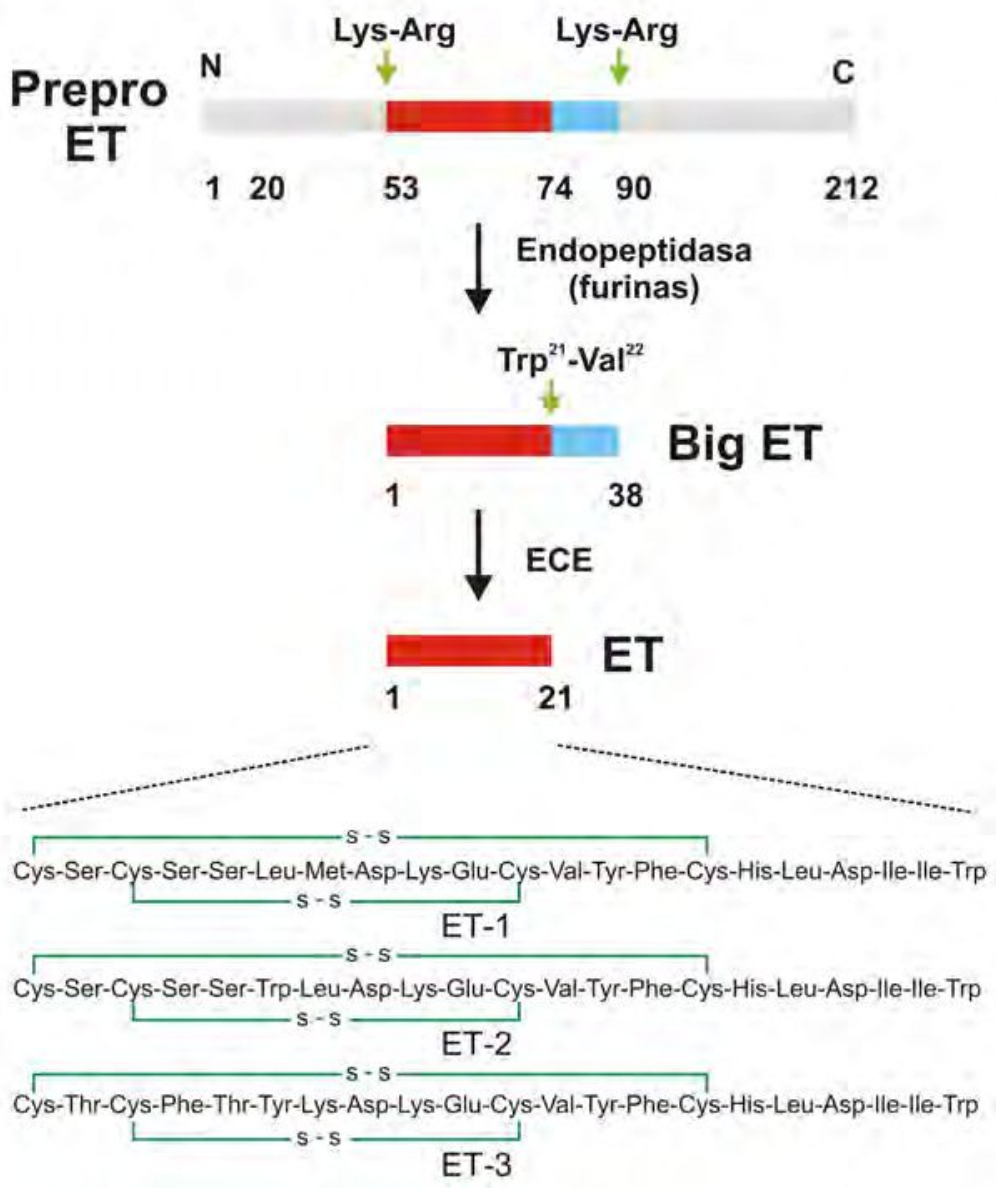

Figura 5: Esquema del procesamiento de la prepro-ET e isoformas de ET.

Las distintas isoformas de ET son producidas en gran variedad de tejidos y tipos celulares. ET-1 se genera en células endoteliales $(94,101)$, pero también la producen el miocardio, el riñón, el sistema nervioso central y el músculo liso vascular (104). ET-2 es sintetizada en riñón, placenta, intestino, corazón y células endoteliales (102). Finalmente, la ET-3 es producida en grandes cantidades en el cerebro y se la encuentra también en miocardio y tracto gastrointestinal $(102,103)$.

En preparaciones multicelulares de miocardio, las tres ET tienen efectos inotrópicos positivos de potencias similares (104). A diferencia de ello, en cultivos de células 
cardíacas aisladas, ET-1 presenta mayor eficacia y potencia en cuanto a su efecto sobre la contractilidad (105).

Al igual que los receptores de Ang II, los de ET se encuentran acoplados a proteína G. Sus siete dominios transmembrana están separados por tres lazos intracelulares y tres extracelulares, el extremo N-terminal es extracelular y el C-terminal intracelular. Inicialmente se identificaron dos tipos de receptores específicos para $E T$, los receptores tipo $A\left(E T_{A}\right)$ y los receptores tipo $B\left(E T_{B}\right)$, con estructura conservada en los mamíferos (106). Ambos se expresan en una amplia cantidad de tejidos, aunque en proporciones variables según el tipo, y se los ha identificado en el corazón de una gran variedad de especies $(107,108)$. Se ha propuesto la existencia de dos subtipos de receptores $E T_{A}, E T_{A 1}$ y $E T_{A 2}$ con diferente sensibilidad a las diferentes isoformas de ET $(104,109)$. En general, la activación de los ET A está estrechamente asociada con vasoconstricción y EIP. El mecanismo involucrado es mediante la disociación de la proteína $G_{q}\left(y / o G_{11}\right)$ y ésta provoca la activación de la PLC $\beta$ que produce traslocación a la membrana, activación de las PKC y sus consecuentes efectos. También, a través de los receptores $E T_{A}$ se activan varias vías de señalización mediadas por quinasas, tal como se mencionó para la acción de Ang II a través de los receptores $\mathrm{AT}_{1}$ (ver figura 3).

Por otra parte, hay evidencia de que existen también dos subtipos de receptores $E T_{B}, E T_{B 1}$ y $E T_{B 2}$, los cuales se asocian a efectos vasodilatadores (mediados por producción de NO y prostaglandina $\mathrm{I}_{2}$ en el endotelio) y vasoconstrictores (directamente sobre músculo liso) respectivamente (110-116). Es probable que en el efecto contráctil mediado por $\mathrm{ET}_{\mathrm{B}}$ esté involucrado el acoplamiento al subtipo de proteína $\mathrm{Ga}_{13}(117)$. 
La afinidad de las diferentes ET por cada receptor es distinta. ET-1 tiene mayor afinidad que $\mathrm{ET}-3$ por el receptor $\mathrm{ET}_{\mathrm{A}}$, sin embargo, las dos isoformas se unen de igual forma al receptor $\mathrm{ET}_{\mathrm{B}}$. ET-2 se une con una afinidad similar a la de ET-1 a ambos receptores (118). Recientemente se ha descubierto, clonado y caracterizado un tercer tipo de receptor de ET, llamado ETc específico para ET-3 y presente en varias especies pero que no se halla en humanos (119).

Las Especies Reactivas derivadas del Oxígeno:

Las especies reactivas derivadas del oxígeno (ERO) incluyen radicales libres como el anión superóxido $\left(\mathrm{O}_{2}^{-}\right)$y el radical hidroxilo $(\cdot \mathrm{OH})$ y compuestos como el peróxido de hidrógeno $\left(\mathrm{H}_{2} \mathrm{O}_{2}\right)$. Estos compuestos participan en reacciones bioquímicas tanto normales como patológicas (120). Las células poseen sistemas antioxidantes intrínsecos que contrarrestan la acumulación de ERO. Estos sistemas incluyen enzimas como la catalasa, la glutatión peroxidasa (GPx) y la superóxido dismutasa (SOD). También poseen sistemas antioxidantes no enzimáticos, como las vitaminas E, C, el $\beta$-caroteno, la ubiquinona, el ácido lipotico y el urato $(120,121)$.

$\mathrm{El} \mathrm{O}_{2}^{-}$es formado intracelularmente por diferentes enzimas: nicotinamida-adenina dinucleotido fosfato oxidasa (NADPH oxidasa), la xantina oxidasa (XO), el desacople de la óxido nítrico sintasa (NOS) y por el transporte y la "fuga" de electrones durante la fosforilación oxidativa en la mitocondria $(120,122,123)$. La SOD convierte el $\mathrm{O}_{2}^{-}$en $\mathrm{H}_{2} \mathrm{O}_{2}$, la cual es convertida a agua por la catalasa y por la GPx. El $\mathrm{H}_{2} \mathrm{O}_{2}$ puede generar $\mathrm{OH}$ a través de la reacción química de Fenton (que involucra átomos de $\mathrm{Fe}^{+3}$ ) en condiciones patológicas (120). 
EI NO es otra molécula importante en el control de la homeostasis cardiovascular. El NO estimula la síntesis de guanidin monofosfato cíclico (GMPc) que es un segundo mensajero intracelular, por la activación de guanilato ciclasa soluble, el GMPc activa a la proteína quinasa G 1 (PKG-1), que a su vez, modula la función, el crecimiento y el remodelado de los miocitos (124). Sin embargo, el NO también interactúa con proteínas a través de la nitrosilación de los residuos de cisteína de las mismas modificando su función $(125,126)$. La nitrosilación se ve facilitada por $\mathrm{O}_{2}^{-}$a niveles fisiológicos, sin embargo, este proceso se inhibe a altos niveles de $\mathrm{O}_{2}{ }^{-}$(120). $\mathrm{El} \mathrm{O}_{2^{-}}$ puede interactuar con el NO para formar peroxinitrito, una de las ERO que es capaz de desencadenar una serie de procesos citotóxicos, entre ellos la peroxidación lipídica, la oxidación y la nitración de proteínas alterando el acoplamiento excitacióncontracción de los miocitos (127) y la activación de metaloproteinasas de la matriz (MMPs) que pueden contribuir al remodelado de la cámara cardíaca $(130,131)$. El NO también puede actuar como antioxidante, ya que inhibe la activación de la XO $(128,129)$ y de la NADPH oxidasa $(130,131)$ y así mantiene la homeostasis de $\mathrm{O}_{2}$ - I NO.

La generación de ERO por la Ang II y la ET-1 ha sido involucrada tanto en señales intracelulares fisiológicas $(120,122,123)$ como patológicas $(134,135)$. La generación de ERO es un componente normal de la fosforilación oxidativa y desempeña un papel en el control redox (reacciones de oxidación/reducción) fisiológico de la señalización intracelular $(120,122,123)$ Las ERO influyen directamente en la función contráctil debido a la modificación de las proteínas fundamentales para el acoplamiento excitación-contracción del miocardio (136). Esto incluye la modificación crítica de grupos tiol $(-\mathrm{SH})$ de los receptores de rianodina para 
aumentar su probabilidad de apertura (137), la supresión de la corriente de $\mathrm{Ca}^{+2}$ de los canales tipo $L(138)$ y la interacción con la bomba de calcio del retículo sarcoplásmico (SERCA) para inhibir la retoma de $\mathrm{Ca}^{+2}$ de la misma $(139,140)$.

En la figura 6 se resumen los mecanismos tanto citosólicos como mitocondriales de producción de ERO.

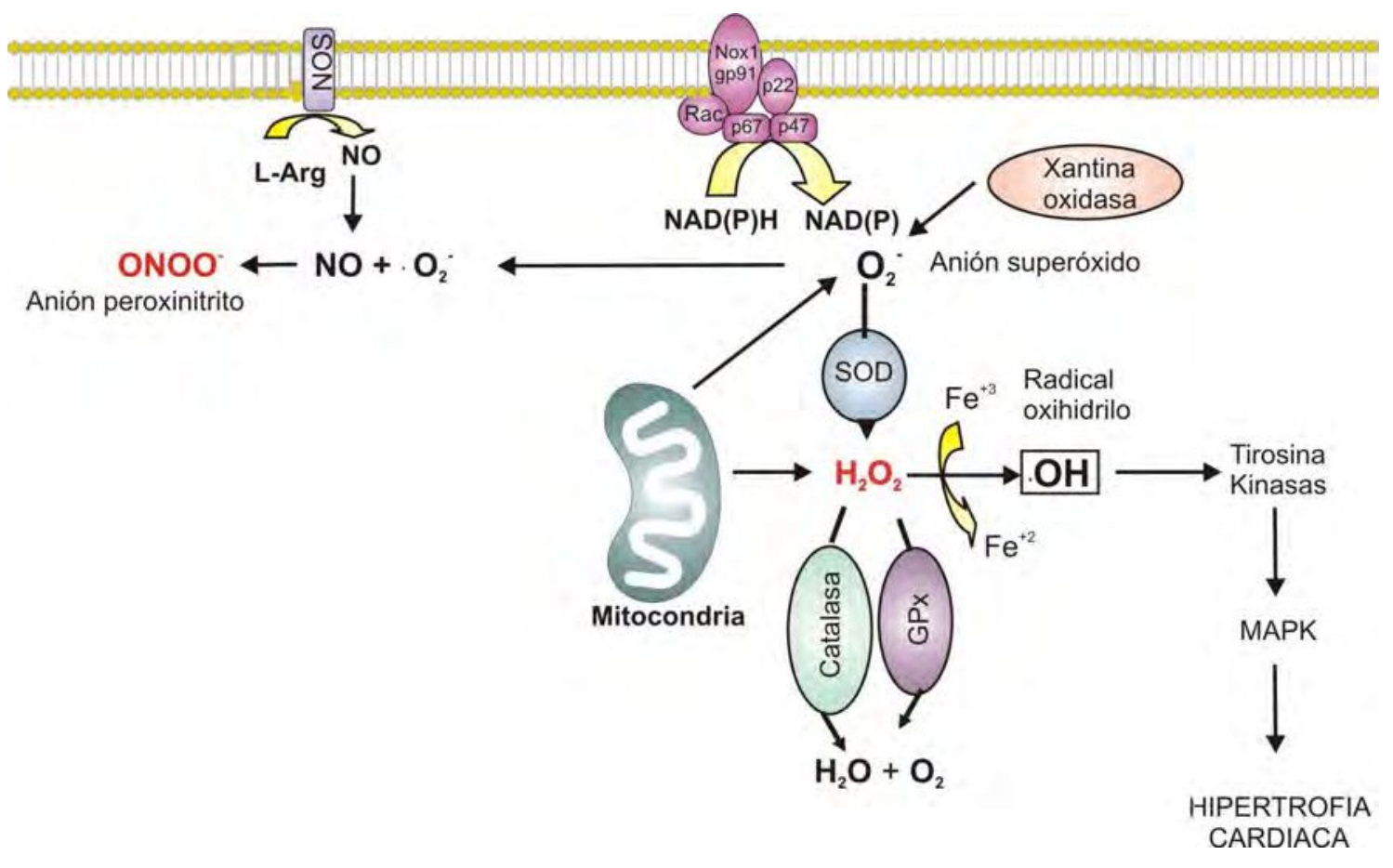

Figura 6: Fuentes celulares y mitocondriales de ERO: La NADPH oxidasa es un complejo enzimático formado por 5 subunidades: Rac, gp91, p22, p47, and p67. NOS: óxido nitrico sintasa. GPx: glutation peroxidasa, SOD: superoxido dismutasa.

El Intercambiador $\mathrm{Na}+/ \mathrm{H}+$

EI NHE es una proteína integral que se encuentra en la membrana plasmática celular. Su función principal es cambiar un $\mathrm{H}^{+}$intracelular por un $\mathrm{Na}^{+}$extracelular, siendo un mecanismo alcalinizante que protege a la célula de la acidificación 
intracelular, constituyendo uno de los principales sistemas regulatorios del $\mathrm{pH}$ intracelular $\left(\mathrm{pH}_{\mathrm{i}}\right)$. También participa en la regulación de flujos de $\mathrm{Na}^{+}$(141).

Existen 9 isoformas del NHE (NHE1 al NHE9); de ellas la isoforma 1 (NHE-1) se encuentra en todas las células eucariotas y es la que predomina en el miocardio. Las otras isoformas poseen una distribución más restringida como por ejemplo, el NHE2 que se encuentra en el tracto intestinal, NHE3 y NHE4 que se encuentran en tejidos excitables como el cerebro; el NHE6 y el NHE7 en cambio se localizan dentro de la célula más que en la membrana plasmática (141).

El NHE-1 contiene 815 aminoácidos que se distribuyen en dos dominios, un dominio integral de membrana y una "cola" citosólica (ver figura 7).

El dominio integral de membrana del NHE-1 es el responsable del movimiento de los cationes. Este dominio tiene doce segmentos transmembrana. Además posee lazos intra y extracelulares, dos de los lazos intracelulares (2 y 4 ) pueden plegarse dentro de la bicapa lipídica y uno de los lazos extracelulares (5) que puede volver a entrar en la misma (142).

\section{Extracelular}

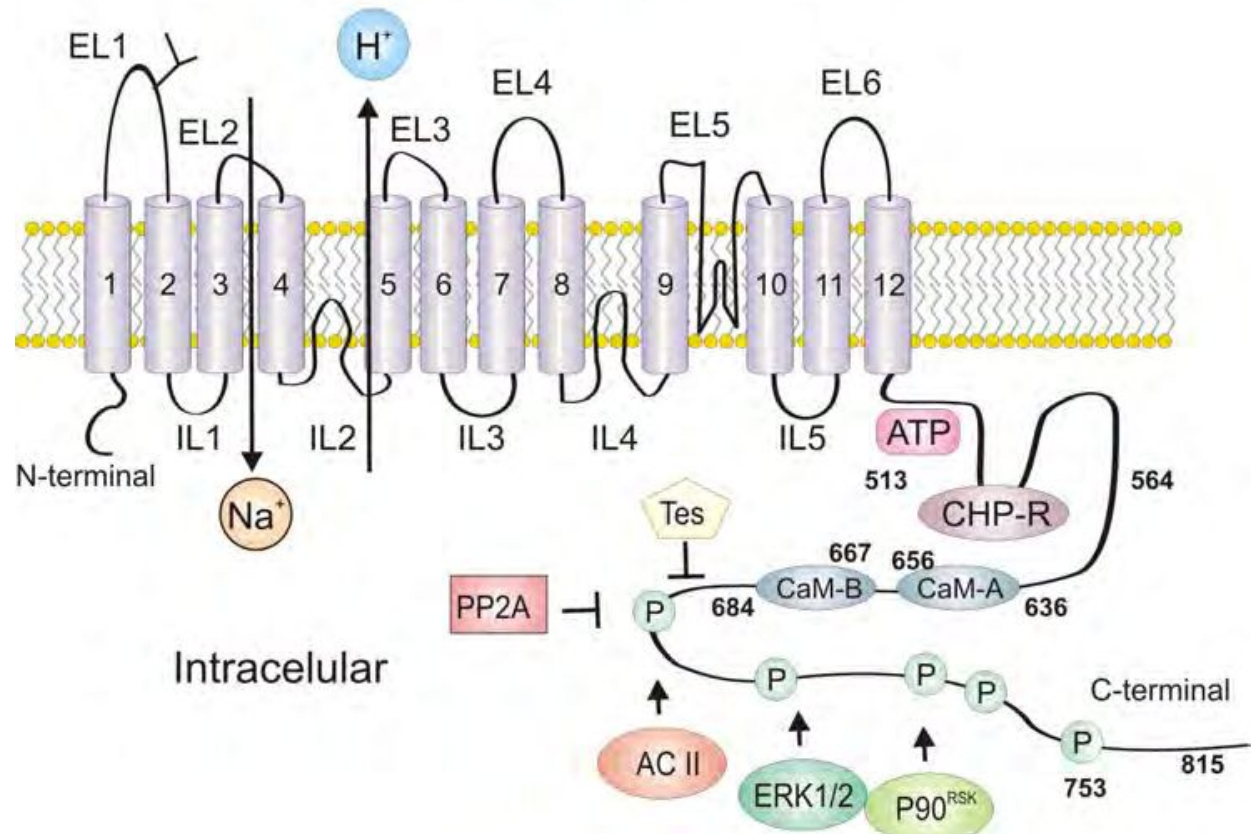


Figura 7: Representación esquemática del NHE-1: está constituido por 12 dominios transmembrana y presenta 2 sitios de glicosilación en los lazos extracelulares. Los extremos, $\mathrm{N}$-terminal y C-terminal son citoplasmáticos. En el extremo C-terminal hay un sitio de unión a ATP, un sitio receptor para proteínas homólogas a calcineurina (CHP-R), dos sitios de unión para calmodulina (CAM-A y CAM-B) y varios residuos fosforilables $(P)$ que están involucrados en la regulación de la actividad del intercambiador en respuesta a diferentes estímulos.

Muchos de los segmentos transmembrana son importantes en la función de la proteína como por ejemplo el segmento transmembrana IV, compuesto por los aminoácidos 152 al 178, es crucial en la función del NHE-1 ya que los residuos Phe 161, Phe 162, Leu 163 y Gly 173 afectan su afinidad por el $\mathrm{Na}^{+}$o su resistencia a los inhibidores (143). Además, en el segmento transmembrana VII compuesto por los aminoácidos 249 al 274, los residuos Glu 262 y Asp 267 también son críticos para la actividad ya que mutaciones en estos residuos por otros con o sin carga eliminan la actividad del NHE-1, mientras que, mutaciones que conserven la carga tienen pequeños efectos sobre su actividad (144).

El NHE-1 posee un dominio citosólico e hidrofóbico largo compuesto por los aminoácidos 500 al 815 que regula la actividad del dominio integral de membrana y es sitio de fosforilación y de unión de proteínas reguladoras. La fosforilación de esta cola citosólica cambia la actividad dependiente de $\mathrm{pH}$ del NHE-1 haciendo al intercambiador más activo a pH más alcalino. En concordancia con esto, experimentos de Sabri y col. (145) muestran que las ERO estimulan al NHE-1 a través de la activación de quinasas capaces de fosforilarlo las cuales incluyen a: PKC, ERK 1/2, p90rsk, p160ROCK, p38 y quinasa NCK-“interactuante” $(146,147)$. También está descripto que numerosas proteínas reguladoras se unen al dominio 
citosólico del NHE-1 incluyendo la calcineurina, calmodulina, tescalcina $(146,147)$ y anhidrasa carbónica II (CAII) (148). Estas proteínas alteran la actividad pH dependiente del NHE-1: calmodulina y CAll tienen roles estimuladores $(148,1149)$, mientras que tescalcina es inhibitoria (147).

La activación del NHE-1 esta asociada con una variedad de eventos incluyendo la proliferación celular. La misma es marcadamente decreciente en células donde el NHE-1 tiene retrasado el punto de regulación que hace que la célula transite el período comprendido entre el fin de la síntesis de DNA y el comienzo de la siguiente mitosis (de $\mathrm{G}_{2}$ a M) (149). También juega un rol en la diferenciación celular dado que la deleción o inhibición del intercambiador deteriora el camino hacia la misma (150). El NHE-1 es importante también en la organización del citoesqueleto y en la migración celular. En algunos tipos de células el NHE-1 está localizado en los lamelipodios donde una cola compuesta por los aminoácidos 553 al 564 actúa como un ancla para los filamentos de actina. Una interrupción de la unión del citoesqueleto por mutación de un aminoácido o inhibición de la actividad del NHE-1, previene la formación de adhesiones locales e inhibe la migración celular (151). 
PROPÓSITO DE TRABAJO:

El propósito general del presente trabajo de Tesis Doctoral fue estudiar la participación de la ET-1 endógena en el desarrollo de HC inducida por Ang II así como las vías de señalización intracelular involucradas.

En virtud de los antecedentes expuestos se elaboró la siguiente hipótesis: la HC patológica se produciría como resultado de la activación de un mecanismo autocrino/paracrino desencadenado por el estiramiento del miocardio y que involucra la liberación de Ang II y ET-1, el aumento de las ERO y la activación del NHE-1. La figura 8 muestra la secuencia propuesta de los eventos que se desencadenarían en los miocitos cardíacos adultos cuando son expuestos a Ang II y/o ET-1.

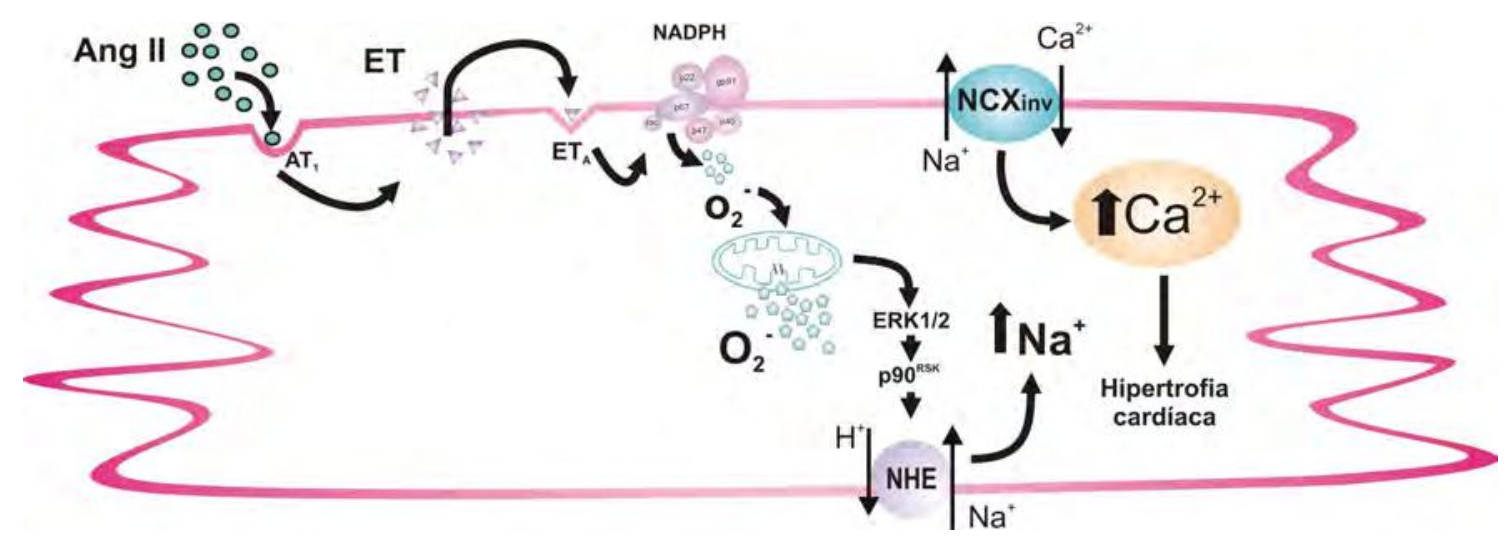

Figura 8: Representación esquemática de la cascada de eventos propuesta luego de la estimulación con Ang II o ET-1. La Ang II activa a sus receptores AT 1 induciendo la liberación/formación de ET, que activa al NHE-1 a través de su interacción con los receptores $\mathrm{ET}_{\mathrm{A}}$. La estimulación del NHE-1 incrementa la [Na+]. El aumento de la $\left[\mathrm{Na}^{+}\right]_{\mathrm{i}}$ favorece el funcionamiento en modo inverso del NCX durante un período de tiempo 


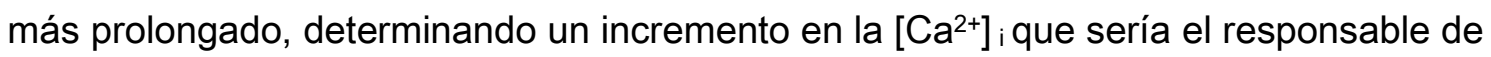
la activación de quinasas y fosfatasas prohipertróficas.

Propósitos particulares.

En el presente trabajo de Tesis Doctoral se intentará:

- Reconocer si concentraciones de Ang II o ET-1 similares a las presentes en el intersticio celular en situaciones fisiológicas cuando son administradas exógenamente son capaces de inducir el desarrollo de HC.

- Evaluar si los efectos hipertrofiantes de Ang II están mediados por ET-1.

- Examinar si en el desarrollo de la HC inducido por Ang II / ET-1 participa el NHE-1.

- Valorar si Ang II estimula la producción de ERO y si está involucrada la ET-1 en ello.

- Explorar si en el desarrollo de HC inducido por Ang II / ET-1 participan las ERO.

- Determinar si la activación de la vía de las MAPKs (ERK 1/2 y p90RSK) está mediada por la producción de ERO.

Debemos señalar que si bien experimentos en miocitos de neonatos sugieren esta serie de eventos, creímos necesario corroborarlo en miocitos adultos ya 
que los mismos presentan características funcionales y vías de señalización intracelulares diferentes (152-155). 


\section{MATERIALES Y MÉTODOS:}

Aislamiento y cultivo de miocitos cardíacos:

Durante el desarrollo de esta Tesis Doctoral se puso a punto la técnica de aislamiento y cultivo de miocitos cardíacos. La misma se realizó de acuerdo a la técnica descripta por Volz y col. (156) con algunas modificaciones. Se anestesiaron los animales con pentobarbital sódico ( $5 \mathrm{~mL}$ de 3,5\% P/v), una vez que los animales estuvieron en la fase de anestesia profunda se abrió el tórax, se visualizó la aorta, se cortó la misma al inicio del cayado y se extrajo el corazón. Rápidamente se colocó el corazón en una bandeja con solución Tyrode $1,35 \mathrm{mmol} / \mathrm{L}$ de $\mathrm{Ca}^{+2}$ (ver tabla) a $37^{\circ} \mathrm{C}$ y burbujeado con oxígeno 100 $\%$ y allí se lo presionó suavemente con el fin de que expulse la mayor cantidad de sangre posible. Seguidamente se inició la perfusión coronaria retrograda tipo Langendorff: se colocó en la aorta una cánula que estaba conectada a una bomba de flujo regulable y se inició la perfusión, así se logró eliminar todo resto de sangre del corazón. Luego se perfundió con otra solución Tydode sin $\mathrm{Ca}^{+2}$ con EGTA $100 \mathrm{mmol} / \mathrm{L}$ durante 5 minutos como máximo con la finalidad de producir el desacople de los discos intercalares y así separar mejor los miocitos de su matriz extra celular. Posteriormente se perfundió la solución de enzimas de digestión que constó de proteasa $0,0015 \%$ y colagenasa $0,065 \%$ durante aproximadamente 25 minutos. Se evidenció la digestión cuando el corazón se tornó flaccido. Posteriormente se descolgó el corazón y se lo cortó en trozos pequeños que luego fueron pipeteados para aumentar la disgregación. El 
producto obtenido, se filtró a través de una malla de nylon de 500 micrones de diámetro y se centrifugó a baja velocidad (400 rpm) durante 3 minutos para poder separar las células de la solución enzimática. El pellet resultante se resuspendió en una solución Tyrode con $0.1 \%$ de albúmina bovina y 0,1 $\mathrm{mmol} / \mathrm{L}$ de $\mathrm{Ca}^{+2}$. En esta misma solución se aumentó progresivamente la concentración de $\mathrm{Ca}^{+2}$ hasta llagar a $1,35 \mathrm{mmol} / \mathrm{L}$ y se procedió a bajar progresivamente la concentración de albúmina bovina. El aumento de $\mathrm{Ca}^{+2}$ extracelular se realizó mediante la adición de distintos volúmenes de medio de cultivo M199. Las células así obtenidas, luego de homogeneizar la suspensión, fueron contadas, para ello se tomó una alícuota $(10 \mu \mathrm{L})$ de la misma que se colocó en una cámara de Neubauer con el fin de conocer la cantidad de miocitos vivos (forma de barra) para sembrar $1,5 \times 10^{5}$ células por $\mathrm{ml}$ de medio ACCT (Medio DMEM suplementado con: albúmina bovina $0.1 \% \mathrm{P} / \mathrm{v}, 2 \mathrm{mmol} / \mathrm{L}$ de L-carnitina, $5 \mathrm{mmol} / \mathrm{L}$ de creatina, $5 \mathrm{mmol} / \mathrm{L}$ de taurina y $10 \mu \mathrm{mol} / \mathrm{L}$ de citosina- $\beta-D$ arabinofuranosido). Se sembró $1 \mathrm{~mL}$ de suspensión de células en placas de $35 \mathrm{~mm}$ de diámetro previamente cubiertas con laminina (10 $\mu \mathrm{g}$ por placa) con el fin de que las células quedaran adheridas a la misma. 


\begin{tabular}{|l|cc|c|c|c|}
\hline DROGA & $\begin{array}{l}1,35 \\
\mathrm{Ca}^{2+}\end{array}$ & 146.2 & 146.2 & 146.2 & 146.2 \\
\hline $\mathrm{NaCl}^{*}$ & 4.69 & 4.69 & 4.69 & 4.69 \\
\hline $\mathrm{KCl}^{*}$ & 11 & 11 & 11 & 11 \\
\hline $\mathrm{Glucosa}^{*}$ & 10 & 10 & 10 & 10 \\
\hline $\mathrm{HEPES}^{*}$ & 0.35 & 0.35 & 0.35 & 0.35 \\
\hline $\mathrm{NaH}_{2} \mathrm{PO}_{4} \mathrm{H}_{2} \mathrm{O}^{*}$ & 1.05 & 1.05 & 1.05 & 1.05 \\
\hline $\mathrm{SO}_{4} \mathrm{MgH}_{2} \mathrm{O}$ & $*$ & no & 0.1 & 0,1 \\
\hline $\mathrm{Cl}_{2} \mathrm{Ca}{ }^{*}$ & 1,35 & 100 & no & no \\
\hline EGTA & no & no & 0.0015 & no \\
\hline Proteasa + & no & no & 0.065 & no \\
\hline Colagenasa+ & no & no & 0.1 & 0.1 \\
\hline Albúmina + & & & & \\
\hline
\end{tabular}

* Concentración en mmol/L.+Concentración en \% p/v. Las soluciones se regulan a $\mathrm{pH}: 7,4$ con $\mathrm{NaOH} 3 \mathrm{~mol} / \mathrm{L}$.

Determinación del efecto hipertrofiante de la Ang II y la ET-1:

Se evaluó el efecto hipertrofiante de concentraciones nanomolares de Ang II $(1 \mathrm{nmol} / \mathrm{L})$ o ET-1 (5 nmol/L) en cultivos primarios de miocitos cardíacos adultos estimulados eléctricamente a $0,5 \mathrm{~Hz}$ durante 18 hs. Para ello se midieron los siguientes parámetros:

1) Incorporación de fenilalanina marcada con tritio $\left(\mathrm{PheH}^{3}\right)$ y normalizada por el contenido de ADN,

2) Tamaño celular: largo, ancho y área celulares,

3) Expresión del $A R N_{m}$ de ANF como gen marcador de $\mathrm{HC}$. 
1) Incorporación de fenilalanina marcada con $\mathrm{H}^{3}$ :

Para esto se cuantificó la incorporación de $\mathrm{PheH}^{3}$ ya que este aminoácido no es producido ni degradado por el tejido cardíaco y atraviesa rápidamente la membrana celular.

Las células se sembraron como se describió anteriormente y se las incubó durante $18 \mathrm{hs}$ en medio ACCT con o sin las drogas en estudio en presencia de L (2,3,4,5,6-H) $\mathrm{PheH}^{3}$. Al final de la incubación se lavó cada placa con buffer fosfato (PBS) $\mathrm{pH} 7.4$ a $0^{\circ} \mathrm{C}$, se colocó $1,5 \mathrm{~mL}$ de ácido tricloroacético al $10 \%$ y se las dejó a $4^{\circ} \mathrm{C}$ durante $12 \mathrm{hs}$. Luego de ese período, se raspó cada placa y el contenido de cada una se colocó en un tubo de 1,5 mL; se centrifugó a 12.000 rpm durante 5 minutos y el pellet de cada muestra así obtenido, se lavó tres veces con ácido tricloroacético al $10 \%$ y dos veces con etanol $95 \%$. Entre cada lavado la suspensión se sonicó para homogeneizarla. Finalmente los pellets se suspendieron en $0,15 \mathrm{~mol} / \mathrm{L}$ de $\mathrm{OHNa}$. Se tomaron alícuotas y se colocaron en un contador de centelleo. Los resultados se expresaron en nanomoles de $\mathrm{PheH}^{3}$ incorporada por disco/ ug de DNA por disco. Para poder expresar los resultados de esta forma debió medirse el DNA de cada muestra.

1.a) Cuantificación de DNA

El contenido de DNA se determinó fluorométricamente por el método de Labarca y Paigen (157) utilizando DNA de esperma de arenque (Biodynamics) 
como estándar. Se tomaron alícuotas del extracto celular obtenido por el método anteriormente descripto y se las diluyó con buffer TNE 10X (10 mmol/L de EDTA, $100 \mathrm{mmol} / \mathrm{L}$ de Tris, $2 \mathrm{mmol} / \mathrm{L}$ de $\mathrm{NaCl}$ ) a las cuales se les agregó una solución de fluoróforo para DNA, H 33258 (American Hoechst Corporation), de concentración $200 \mathrm{ng} / \mathrm{mL}$ en buffer TNE 1X. La fluorescencia se determinó con un espectrofluorómetro (Beckman) con una longitud de onda de emisión y excitación de $450 \mathrm{~nm}$ y $350 \mathrm{~nm}$ respectivamente.

Todas las intervenciones que se realizaron en los cultivos celulares se hicieron en presencia de los siguientes agonistas o bloqueantes en forma aislada o combinada:

Ang II (1nmol/L),

Losartán $(1 \mu \mathrm{mol} / \mathrm{L})$ : antagonista selectivo de receptores $A T_{1}$,

BQ123 (10 $\mu \mathrm{mol} / \mathrm{L}):$ antagonista selectivo de los receptores $\mathrm{ET}_{\mathrm{A}}$,

ET-1 (5 nmol/L),

HOE642 (10 $\mu \mathrm{mol} / \mathrm{L})$ : inhibidor del NHE-1;

Mercaptopropionilglicina (MPG $2 \mathrm{mmol} / \mathrm{L}$ ): capturador de ERO.

2) Tamaño celular: largo, ancho y área celulares.

Se sembraron las células como se describió anteriormente y al final del tratamiento las células se enjuagaron dos veces con PBS. Se seleccionaron al azar 50 células por situación. Las imágenes se capturaron con una cámara de 
video analógica y se digitalizaron y procesaron con un programa morfométrico Image-Pro Plus $6.0 \mathrm{U}$ (W. Rasband, National Instutute of Health. USA). En la figura 9 se pueden observar fotomicrografías representativas de los diferentes cultivos de miocitos marcapaseados durante $18 \mathrm{hs}$. las cuales se utilizaron para evaluar el tamaño celular.
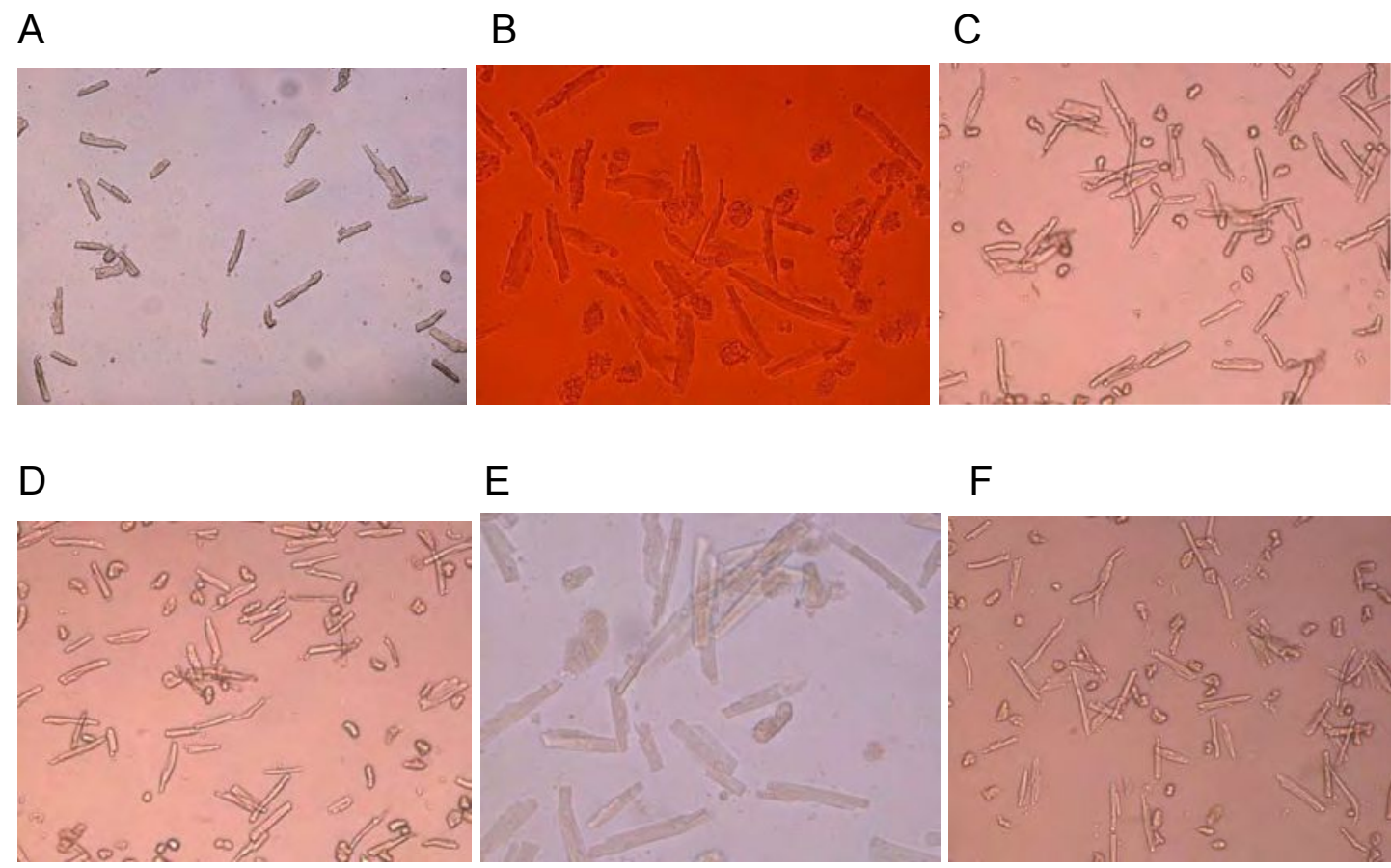

E

$\mathrm{F}$

Figura 9: Fotomicrografías representativas de los cultivos de células estimuladas durante 18 hs. A. control, B: tratadas con Ang II, C: tratadas con Ang II + Losartán, D: control, E: ET-1, F: ET-1 + MPG.

Todas las intervenciones que se realizaron en los cultivos celulares se hicieron en presencia de los siguientes agonistas o bloqueantes en forma aislada o combinada:

Ang II (1 nmol/L),

Losartán $(1 \mu \mathrm{mol} / \mathrm{L})$ : antagonista selectivo de receptores $\mathrm{AT}_{1}$,

BQ123 (10 $\mu \mathrm{mol} / \mathrm{L})$ : antagonista selectivo de los receptores $\mathrm{ET}_{\mathrm{A}}$; 
ET-1 (5 nmol/L),

HOE642 (10 $\mu \mathrm{mol} / \mathrm{L})$ : inhibidor del NHE-1;

MPG (2 mmol/L): capturador de ERO.

3) Expresión del $A R N_{m}$ de ANF como gen marcador de HC.

Se evaluó la expresión del $A R N_{m}$ de ANF (Factor Natriurérico Atrial) como marcador de HC mediante la técnica de RT-PCR en tiempo real.

Se realizó la determinación del $A R N_{m}$ del $A N F$ a partir de $A R N$ total de miocitos cultivados. Se utilizó como estándar interno el $A R N_{m}$ de GAPDH (ver más adelante).

Aislamiento de ARN total

A partir de 500.000 a 750.000 miocitos por tratamiento, conservados en RNAlater (Qiagen) a $-80^{\circ} \mathrm{C}$ se realizó el asilamiento de ARN total utilizando el kit RNeasy (Qiagen) y siguiendo las instrucciones del fabricante. Las muestras, una vez descongeladas, se homogeneizaron empleando el homogeinizador Pro 250 (Pro Scientific Ltd.) durante 20 segundos en el buffer de lisis provisto en el kit, conteniendo isotiocianato de guanidina y $\beta$-mercaptoetanol para proveer condiciones desnaturalizantes y permitir la inmediata inactivación de ribonucleasas. A continuación, las muestras se sometieron a 10 minutos de digestión proteica a $55^{\circ} \mathrm{C}$ empleando proteinasa $\mathrm{K}$ (Invitrogen) y se cargaron las columnas del kit, previamente se adicionó etanol para ajustar las condiciones de 
unión del ARN a la fase sólida. Se llevaron a cabo 3 pasos de lavado, digestión con desoxirribonucleasa (Qiagen) durante 15 minutos a temperatura ambiente para eliminar interferencias de ADN y finalmente se eluyó el ARN con $50 \mu \mathrm{L}$ de agua libre de nucleasas (Qiagen). Toda la manipulación de las muestras y la preparación de soluciones a partir de la elución del ARN purificado se realizaron con puntas de pipeta con filtro y agua libre de nucleasas.

Determinación de la concentración de ARN:

La concentración de ARN se determinó mediante la lectura de absorbancia a $260 \mathrm{~nm}\left(\mathrm{~A}_{260}\right)$ en espectrofotómetro (SmartSpec 3000, Bio-Rad). Para ello se realizó una dilución apropiada del ARN purificado en agua, usualmente 1/10, para asegurar lecturas mayores de 0.15 unidades de absorbancia, y se midió la $\mathrm{A}_{260}$ utilizando cubetas de $50 \mu \mathrm{L}$ transparentes a la luz UV y llevando la absorbancia a cero con agua.

Para la cuantificación se consideró que la absorbancia de 1 unidad a 260 $\mathrm{nm}$ corresponde a una concentración de ARN de $40 \mu \mathrm{g} / \mathrm{mL}$.

Transcripción reversa

Este paso tiene como objetivo la obtención de una cadena de ADN copia (ADNc) del $A R N_{m}$ de $A N F$, para poder ser utilizada como molde en la reacción de PCR. Se realizó utilizando transcriptasa reversa Omniscript (Qiagen). La enzima posee actividad de ADN-polimerasa dependiente de molde de ARN y actividad de exoribonucleasa dependiente de una doble cadena híbrida ARN: ADN. Los pasos de la reacción incluyen: a) hibridización de cebadores o 
"primers", necesarios como punto de partida para el inicio de la actividad de polimerización de la enzima; b) RT propiamente dicha, consistente en la síntesis de una cadena de ADN partiendo del primer y utilizando un molde de ARN; y c) degradación del ARN presente en cadenas híbridas ARN:ADN, esta actividad de exorribonucleasa sólo actúa sobre el ARN hibridizado al ADNc sintetizado, y no afecta al ARN de cadena simple.

Como cebadores de la reacción se utilizaron los primers antisentido diseñados a partir de la secuencia del gen de ANF y de GAPDH de gato:

Primer antisentido para ANF: 5'-CTCCAAATGGTCCAGCAAAT-3'

Primer antisentido para GAPDH: 5'-AGAAGGGGCAGAGATGATGA-3'

Para cada muestra experimental de ARN purificado se preparó la siguiente mezcla de reacción en tubos de PCR de $200 \mu \mathrm{L}$ libres de ribonucleasas y manipulando todos los reactivos en baño de hielo:

- Mezcla de desoxinucleótidos trifostato (dNTPs): $0.5 \mathrm{mmol} / \mathrm{L}$ de cada uno (dATP, dCTP, dGTP, dTTP).

- Primer antisentido $1 \mu \mathrm{M}$ de cada uno (ANF y GAPDH).

- Inhibidor de ribonucleasas (Invitrogen): 10 Unidades.

- Transcriptasa reversa Omniscript (Qiagen): 4 Unidades.

$-1.6 \mu g$ de ARN.

- Buffer de reacción (Qiagen): hasta completar $20 \mu \mathrm{L}$.

La reacción se llevó a cabo durante 60 minutos a $37^{\circ} \mathrm{C}$, seguidos de 5 minutos de inactivación de la enzima a $95^{\circ} \mathrm{C}$ y enfriado a $4^{\circ} \mathrm{C}$, en un ciclador 
térmico (PTC-150 Mini Cycler). Se conservó el ADNc obtenido a $-80^{\circ} \mathrm{C}$ hasta el momento de su utilización como molde en la RT-PCR en tiempo real.

RT-PCR en tiempo real

Fundamentos: Este método conserva el fundamento de una PCR estándar con la posibilidad adicional de seguir en tiempo real el curso de la reacción y calcular así parámetros mediante los cuales se puede estimar la cantidad inicial de ADNc utilizado como molde. Como en cualquier PCR, la real time PCR consiste en ciclos sucesivos de desnaturalización de la doble hebra de ADN, hibridización de los primers al ADN molde, síntesis de la cadena complementaria mediante una polimerasa resistente al calor (Taq polimerasa) y nuevamente desnaturalización del ADN doble cadena para recomenzar el ciclo.

En cada ciclo la cantidad de ADN se duplica y, en condiciones ideales, en un ciclo dado $(n)$, el número de copias de $\operatorname{ADN}\left(\mathrm{N}_{n}\right)$ podría calcularse según la ecuación $\mathrm{N}_{\mathrm{n}}=\mathrm{N}_{0} \times 2^{n}$, donde $\mathrm{N}_{0}$ es el número de copias inicial. El crecimiento exponencial del número de copias de ADN ocurre hasta que los reactivos se agotan y/o se produce inhibición por producto. La real time PCR se lleva a cabo en un ciclador térmico que tiene acoplado un detector óptico que mide la fluorescencia en cada ciclo y en cada reacción individual. En la técnica empleada en este trabajo, se utilizó el indicador SYBR Green I que emite fluorescencia a 490 $\mathrm{nm}$ al unirse al surco menor del ADN doble cadena. El equipo ciclador permite programar las condiciones para obtener una lectura de fluorescencia en cada ciclo al finalizar la etapa de polimerización y antes de la etapa de desnaturalización de 
la doble hebra. De esta manera, se obtiene para cada reacción individual una curva de amplificación, que se define como la curva de fluorescencia en función del número de ciclos. En ella se distinguen tres fases: 1) una fase inicial en la que debido a una cantidad aún baja de ADN los cambios de fluorescencia no son detectados por el equipo y por lo tanto la señal es aproximadamente constante; 2) una fase exponencial donde se observa el mayor crecimiento de fluorescencia con el número de ciclos; y 3) una fase de meseta o declinación, en la que la fluorescencia es constante o crece más lentamente.

Intuitivamente es posible deducir que cuanto mayor sea la cantidad de ADN inicial, más pronto se observará un aumento significativo de fluorescencia en el curso de la reacción. La fase inicial de la curva de amplificación define una línea de base por encima de la cual se detecta la acumulación del producto de PCR. Al establecer arbitrariamente una línea umbral por encima de esta línea de base, se define el parámetro $\mathrm{C}_{u}$ (ciclo umbral) como el número fraccional de ciclos en el que la fluorescencia intersecta la línea umbral.

Procedimiento: Cada PCR se realizó por triplicado, tanto para ANF como para GAPDH, partiendo de una dilución 1/10 del producto obtenido en la RT. Los primers utilizados fueron:

\section{GAPDH}

primer sentido 5'-GGTGATGCTGGTGCTGAGTA-3' y primer antisentido 5'-AGAAGGGGCAGAGATGATGA-3'; 
primer sentido 5'-TGTCAGCTCTTGTGGCAAAC-3'

primer antisentido 5'-CTCCAAATGGTCCAGCAAAT-3'.

Las reacciones se prepararon en placa de 96 pocillos, con la siguiente composición

- dNTPs (Amersham) $0.2 \mathrm{mmol} / \mathrm{L}$ de cada uno.

- MgCl2 (Invitrogen) $1.5 \mathrm{mM}$.

- Fluoresceína (Bio-Rad) 10 nmol/L.

- SYBR Green I (Molecular Probes) dilución 1/1000: 0.8 (L/reacción.

- Primers (Operon) 0.5 ( $\mathrm{M}$ de primer sentido y 0.5 ( $\mathrm{M}$ de primer antisentido.

- Taq ADN polimerasa (Invitrogen) 1.25 Unidades/reacción.

- ADNc molde: dilución 1/10 de la RT.

- Buffer de PCR (Invitrogen): hasta un volumen de 25 (L/reacción.

Además se realizó una curva de eficiencia para cada gen con diluciones $1 / 2,1 / 10$ y $1 / 100$ de una mezcla constituida por todos los productos de RT obtenidos (pool), cada punto de la curva se realizó también por triplicado. Como control negativo se prepararon mezclas de reacción que en lugar de contener ANDc molde, se cargaron con agua bidestilada. Una vez realizadas todas las mezclas de reacción se cubrió la placa con una pieza de film óptico (Bio-Rad) y se llevó a cabo la reacción en un equipo para PCR en tiempo real (iCycler, Bio-Rad). Todos los parámetros derivados de esta reacción fueron calculados utilizando el programa Real-Time Detection System Software, versión 3.0 (Bio-Rad). 
Todas las intervenciones que se realizaron a los cultivos celulares se hicieron en presencia de los siguientes agonistas o bloqueantes en forma aislada 0 combinada:

$\mathrm{ET}-1(5 \mathrm{nmol} / \mathrm{L})$,

MPG (2 mmol/L): capturador de ERO,

EMD87580 (5 $\mu \mathrm{mol} / \mathrm{L})$ : inhibidor del NHE-1.

Determinación del papel de las ERO en el desarrollo de HC por Ang II:

Se evaluó mediante mediciones de ERO por medio de epifluorescencia del indicador desesterificado:

Los miocitos se incubaron durante 60 minutos a temperatura ambiente con 20 $\mu \mathrm{mol} / \mathrm{L}$ de diacetato de dicloro-hidrofluoresceina $\mathrm{H}_{2} \mathrm{DCFDA}$ (Molecular Probes), en su forma esterificada que es un indicador fluorescente para medir ERO. Luego de la incubación las células se lavaron con buffer sin indicador, la desesterificación por parte de las estearasas intracelulares transforma así el indicador en un compuesto que se fija a las ERO que se quieren medir lo cual modifica sus propiedades fluorescentes. Luego los miocitos fueron colocados sobre una cámara de perfusión que se encuentra sobre la platina de un microscopio invertido (Nikon Eclipse 2000) y fueron excitados con luz de longitud de onda de $490 \mathrm{~nm}$. El indicador $\mathrm{H}_{2}$ DCFDA se usó con simple excitación y emisión. La fluorescencia que emitieron los miocitos, luego del 
paso por un multiplicador con filtro de $535 \mathrm{~nm}$, se registró con un convertidor digital conectado a una computadora (lonoptix System). A cada señal fluorescente se le restó la fluorescencia basal del sistema (incluidas las células) obtenida en ausencia de indicador. Los resultados se expresaron en \% de aumentos respecto de la situación control.

Todas las intervenciones que se realizaron a los miocitos aislados se hicieron en presencia de los siguientes agonistas o bloqueantes en forma aislada o combinada:

Ang II (1 nmol/L),

Losartán (1 $\mu \mathrm{mol} / \mathrm{L})$ : antagonista selectivo de receptores $A T_{1}$,

TAK044 (1 $\mu \mathrm{mol} / \mathrm{L})$ : bloqueante no selectivo de receptores de ET-1, BQ123 (10 $\mu \mathrm{mol} / \mathrm{L})$ : antagonista selectivo de los receptores $\mathrm{ET}_{\mathrm{A}}$, MPG (2 mmol/L): capturador de ERO.

Determinación de participación de las MAPK relacionada con la producción de $\mathrm{HC}$.

Se basó en la técnica de Western blot con anticuerpos específicos para las formas fosforiladas de MAPKs (ERK 1/2 y p90RSK).

Se utilizaron 500.000 a 750.000 miocitos aislados por tratamiento experimental, luego de homogeneizarlos en buffer RIPA con inhibidores de proteasas (300 
$\mathrm{mmol} / \mathrm{L}$ de sacarosa, $1 \mathrm{mmol} / \mathrm{L}$ de DTT, $4 \mathrm{mmol} / \mathrm{L}$ de EGTA, $20 \mathrm{mmol} / \mathrm{L}$ de Tris, $1 \%$ de Tritón y 1 tableta de Complete Mini cada $15 \mathrm{~mL}$ de buffer) se guardaron las muestras a $-80^{\circ} \mathrm{C}$. Posteriormente las mismas se descongelaron en baño de hielo y se procedió a la determinación de la concentración de proteína presente en cada una. Para tal fin se empleó el método espectrofotométrico de Bradford (BioRad Protein Assay) siguiendo las instrucciones del fabricante. Partiendo de diluciones apropiadas de las muestras se realizaron las determinaciones por triplicado, leyendo la absorbancia a $595 \mathrm{~nm}$, con sustracción del blanco de reactivos, en un espectrofotómetro UV/visible (SmartSpec 3000, Bio-Rad). La cuantificación se realizó a partir de una curva de calibración realizada con 4 diluciones de albúmina bovina (Sigma-Aldrich).

Preparación de las muestras para Western blot: las mismas se descongelaron en baño de hielo. Se tomó el volumen adecuado de cada una según la proteína a analizar y se procedió a la desnaturalización y preparación para la electroforesis utilizando buffer de muestra y $10 \%$ de agente reductor (ambos de Invitrogen). Se completó con agua bidestilada para alcanzar el volumen a sembrar en el gel en cada caso. Todo este procedimiento se realizó en baño de hielo. Las muestras se desnaturalizaron en baño termostático (Precision) a $70^{\circ} \mathrm{C}$ durante 10 minutos.

Electroforesis: para la separación electroforética de las proteínas se utilizaron geles preensamblados de poliacrilamida en gradiente $4-12 \%$ Bis-Tris 
(Invitrogen) y dilución adecuada del buffer 20X (Invitrogen) de composición $1.00 \mathrm{~mol} / \mathrm{L}$ de MOPS, $1.00 \mathrm{~mol} / \mathrm{L}$ de Tris base, $69.3 \mathrm{mmol} / \mathrm{L}$ de SDS, 20.5 $\mathrm{mmol} / \mathrm{L}$ de EDTA y agua bi-destilada hasta $500 \mathrm{~mL}, \mathrm{pH}$ 7.7. Al buffer reconstituido utilizado para la cámara interna se le agregó agente reductor (Invitrogen) en una concentración final de $0.1 \%$. Se sembró un volumen apropiado de las muestras en el gel, más $1 \mu \mathrm{L}$ de marcador de pesos moleculares (MagicMarc, Invitrogen). La corrida electroforética se realizó a temperatura ambiente y a $200 \mathrm{~V}$, suministrados por una fuente de poder PS 251-2 (Sigma-Aldrich). La corrida se prolongó durante el tiempo necesario para que el frente de solvente alcanzara el extremo del gel (aproximadamente 45-60 minutos).

Transferencia: las proteínas así separadas por su peso molecular fueron transferidas a membranas de PVDF (Millipore). Se empleó una dilución adecuada del buffer de transferencia 20X (Invitrogen) con la siguiente composición: $500 \mathrm{mmol} / \mathrm{L}$ de glicina, $500 \mathrm{mmol} / \mathrm{L}$ de Bis-Tris, $20.5 \mathrm{mmol} / \mathrm{L}$ de EDTA, $1 \mathrm{mmol} / \mathrm{L}$ de clorobutanol y agua ultrapura hasta $600 \mathrm{~mL}$. Al reconstituir el buffer se le adicionó metanol (Carlo Erba) y agente reductor (Invitrogen) en una concentración final de 10 y $0.1 \%$, respectivamente. Las membranas se activaron sumergiéndolas durante 30 segundos en metanol, luego se las enjuagó con agua bidestilada y se las dejó en el buffer de transferencia durante varios minutos para que se equilibren, al igual que los papeles de filtro y las esponjas utilizadas en el sandwich. La transferencia se llevó a cabo con la cuba 
en baño de hielo, utilizando el voltaje y el tiempo apropiados en cada caso. Una vez finalizada, se retiraron las membranas y se corroboró la presencia de proteínas en la misma mediante la tinción reversible con Ponceau $(0.1 \%$ Ponceau en $0.5 \%$ de ácido acético) y posteriormente se enjuagó con T-TBS (0.05 $\mathrm{mol} / \mathrm{L}$ de tris base, $0.15 \mathrm{~mol} / \mathrm{L}$ de $\mathrm{NaCl}, 200.1 \%$ de Tween).

Bloqueo: las membranas se bloquearon durante 60 minutos en agitador orbital (Decalab) a temperatura ambiente con solución en T-TBS de leche en polvo descremada (Molico) o de BSA en concentración apropiada.

Incubación con anticuerpo primario específico: luego de un breve enjuague con T-TBS de la solución de bloqueo, se incubaron las membranas con $10 \mathrm{~mL}$ de la dilución correspondiente de anticuerpo primario contra la proteína de interés, en T-TBS adicionado con $1 \%$ de BSA durante 12 hs a $4^{\circ} \mathrm{C}$, con agitación orbital.

Lavado del anticuerpo primario: para eliminar el anticuerpo primario que se hubiere adherido inespecíficamente a la membrana, luego de retirar el anticuerpo primario se realizaron 4 lavados con T-TBS a temperatura ambiente en agitador orbital. El primero de 5 minutos y los tres siguientes de 10 minutos cada uno.

Incubación con anticuerpo secundario: las membranas se incubaron durante 60 minutos a temperatura ambiente y con agitación, con $10 \mathrm{~mL}$ de la dilución apropiada del anticuerpo secundario correspondiente en T-TBS adicionado con $1 \%$ de BSA. El anticuerpo secundario está acoplado a la enzima peroxidasa de 
rábano (HRP) y está diseñado para reconocer la fracción Fc específica de la especie en la que se obtuvo el anticuerpo primario, haciendo de nexo de esta manera entre la proteína de interés y el sistema posterior de detección.

Lavado del anticuerpo secundario: se realizó de la misma manera que el lavado del anticuerpo primario.

Revelado: se utilizó el sistema de detección ECL Plus (Amersham) de acuerdo a las instrucciones del fabricante. La reacción se basa en la generación de éster de acridinio a partir de un sustrato, agua oxigenada y la HRP, en las condiciones alcalinas del medio esta sustancia se oxida generando un producto excitado que emite señal quimioluminiscente que puede ser detectada y cuantificada. La detección se realizó mediante la cámara CCD de un equipo Chemidoc XRS (Bio-Rad), que captura y digitaliza las imágenes.

Cuantificación: se cuantificó la intensidad de las bandas por densitometría utilizando el programa Scion Image.

Todas las intervenciones que se realizaron a los miocitos aislados se hicieron en presencia de los siguientes agonistas o bloqueantes en forma aislada 0 combinada:

$\mathrm{ET}-1$ (5 nmol/L), MPG (2 mmol/L): capturador de ERO.

\section{Análisis estadístico}


Los datos se presentan como media \pm error estándar (ES). Para comparar 2 intervenciones se utilizó test de $\mathrm{t}$ de Student para muestras desapareadas. Un valor de $p<0.05$ se consideró como estadísticamente significativo. Para comparar más de 2 intervenciones se usó ANOVA de una vía para muestras independientes seguido de un test de Student-Newman-Keuls. Un valor de $\mathrm{p}<0.05$ se consideró como estadísticamente significativo.

Se usó el programa Primer of Biostatistics (McGraw Hill) para realizar estas pruebas estadísticas. 


\section{RESULTADOS:}

\section{Efecto hipertrofiante de Ang II:}

El efecto hipertrofiante de Ang II fue evaluado en miocitos cardíacos aislados mediante la estimación de dos parámetros: 1) incorporación de ${ }^{3} \mathrm{H}$ fenilalanina/DNA y 2) tamaño celular (largo, ancho y área)

Se cultivaron cardiomiocitos aislados de corazones de gatos adultos en presencia o ausencia de Ang II, marcapaseados a $0.5 \mathrm{~Hz}$ durante $18 \mathrm{hs}$. Los resultados se expresaron en porcentaje respecto del control (valor $100 \%$ ). En la figura 10 se observa que la Ang II produjo un aumento de la incorporación de ${ }^{3} \mathrm{H}$ fenilalanina/DNA a un valor de $137 \pm 7.7 \%(n=12 p<0.05)$. Este efecto, fue cancelado cuando los miocitos se cultivaron en presencia del bloqueante de los receptores AT1, Losartán (Ang II + Losartán, $110 \pm 7.4 \%$ n= 12).

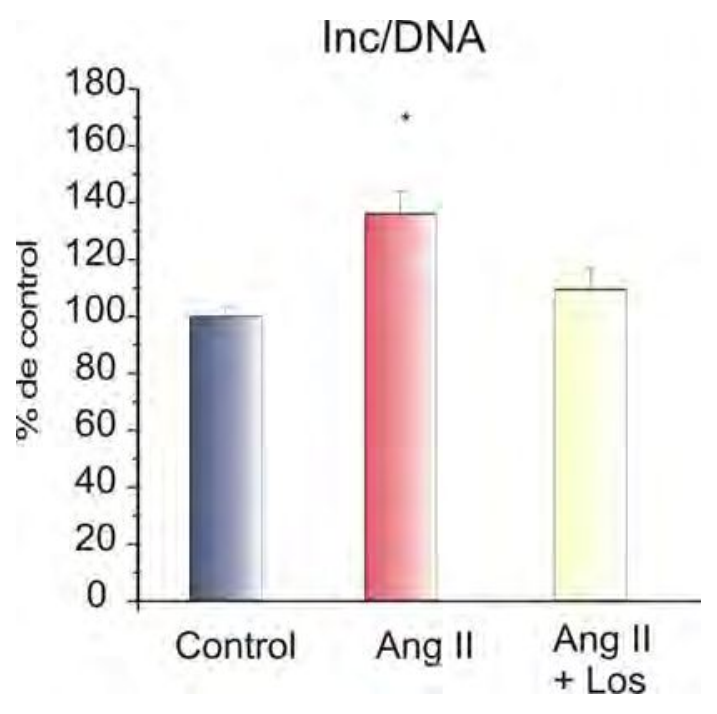

Figura 10: Incorporación de ${ }^{3} \mathrm{H}$ fenilalanina/DNA, resultados promedio de $n=12 .{ }^{*}=p<$ 0.05 vs. control, analizado por ANOVA. 
Cuando se evaluó el tamaño celular la Ang II aumentó el valor del largo de los cardiomiocitos al $131 \pm 3.3 \%$, el valor del ancho al $117 \pm 5.1 \%$ y el valor del área al $145 \pm 5.9 \%$ como se muestra en la figura 11 . En presencia de Ang II + Losartán el aumento del tamaño fue cancelado ya que, las células así cultivadas no modificaron los valores de su largo (99 $\pm 1.0 \%)$, ni de su ancho (97 $\pm 2.7 \%)$ ni de su área $(97 \pm 2.0 \%)$. Para cada parámetro $n=9 p<0.05$ vs. de Ang II, ANOVA.
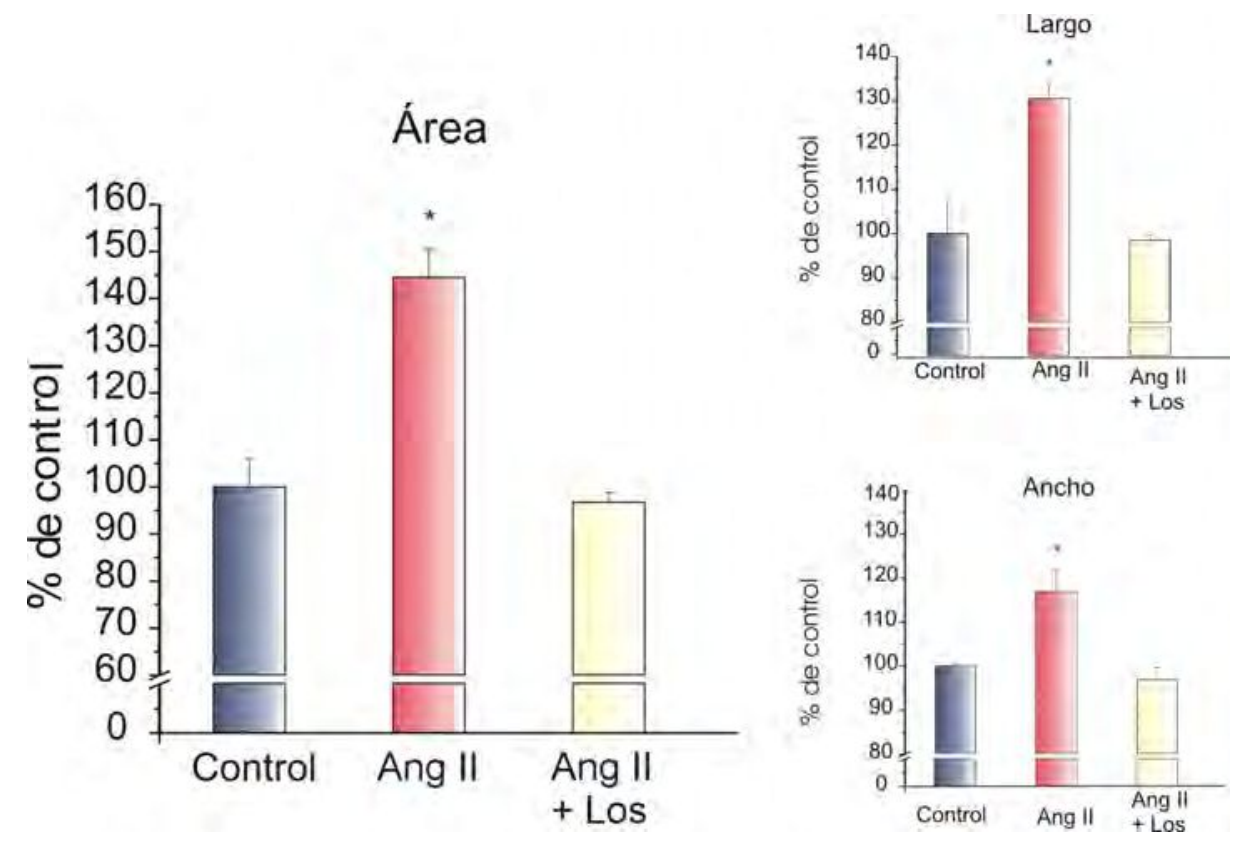

Figura 11: Resultados promedio del tamaño celular de $n=9$ expresados como \% respecto de control. ${ }^{*}=p<0.05$ vs. control, analizado por ANOVA.

Los datos presentados en las figuras 10 y 11 sugieren entonces, en nuestro modelo experimental, que el efecto hipertrofiante de la Ang II es debido a un aumento de la síntesis proteica que produce un aumento del tamaño celular. 
Efecto hipertrofiante de Ang II mediado por ET-1:

Con el fin de establecer si la ET-1 estaba involucrada en el efecto hipertrofiante de la Ang II, se cultivaron miocitos siguiendo el mismo protocolo experimental pero con Ang II en presencia de $\mathrm{BQ} 123$ que es un bloqueante de los receptores $\mathrm{ET}_{\mathrm{A}}$ de $\mathrm{ET}-1$. Como se muestra en la figura 12, $\mathrm{BQ} 123$ disminuyó el valor de la incorporación de ${ }^{3} \mathrm{H}$ fenilalanina/DNA inducido por Ang II ya que el mismo fue $114 \pm 7.4 \%$, $(n=12)$.

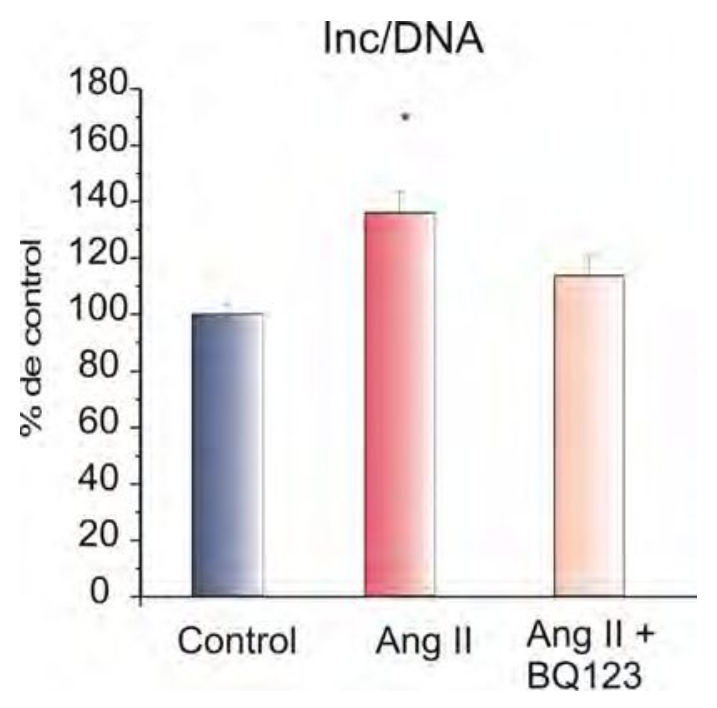

Figura 12: Incorporación de $3 \mathrm{H}$ fenilalanina/DNA, resultados promedio de $\mathrm{n}=12$. * significa distinto de control, $p<0.05$, analizado por ANOVA.

Con respecto al tamaño celular el aumento del mismo que provocó la Ang II, también fue prevenido por BQ 123 como se muestra la figura 13. Cuando las células fueron tratadas con Ang II+BQ 123 el valor para el largo fue de un $99 \pm$ 
$1.3 \%$, el valor para el ancho fue de un $101 \pm 1.5 \%$ y el valor para el área fue de $99 \pm 2.5 \%$ respecto de control $(n=9)$.
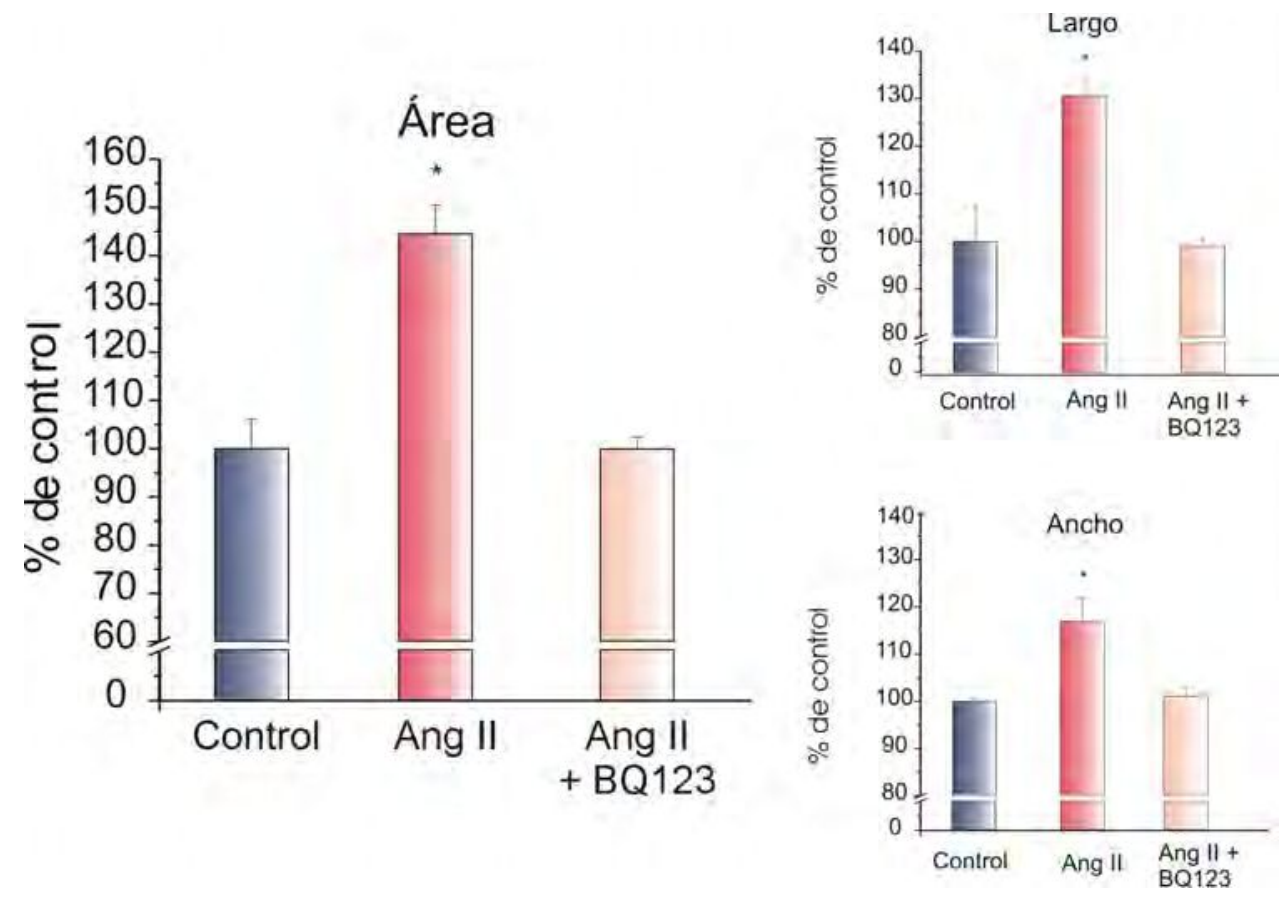

Figura 13: Resultados promedio del tamaño celular de $n=9$ expresados como $\%$ respecto de control. ${ }^{*}=p<0.05$ vs. control, analizado por ANOVA.

Los resultados obtenidos en los experimentos anteriores sugieren que el efecto hipertrofiante de Ang II esta mediado por ET-1 endógena, la cual actúa en forma autocrina. La presencia en el miocito felino de los precursores de la ET1: preproendotelina, big-endotelina y enzima convertidora de ET-1 ha sido demostrada previamente en este laboratorio (158).

Efecto hipertrofiante de ET-1: 
Si el efecto hipertrofiante de Ang II es el resultado de la liberación de ET-1 por parte del miocito cardíaco actuando de forma autocrina, se debería poder reproducir este efecto mediante la exposición de miocitos cardíacos a ET-1 exógena. El efecto hipertrofiante de ET-1 exógena fue evaluado en cardiomiocitos aislados mediante la medición de tres parámetros 1) incorporación de ${ }^{3} \mathrm{H}$ fenilalanina/DNA y 2) tamaño celular de los miocitos (largo, ancho y área) y 3) expresión del $\mathrm{ARN}_{\mathrm{m}}$ de ANP.

Siguiendo el protocolo experimental utilizado para explorar el efecto hipertrofiante de la Ang II se cultivaron cardiomiocitos aislados de corazones de gatos adultos marcapaseados a $0.5 \mathrm{~Hz}$. durante $18 \mathrm{hs}$ en presencia o ausencia de ET-1. Como se muestra en las figuras 14 y 15 las células tratadas con ET-1 aumentaron la incorporación de ${ }^{3} \mathrm{H}$ fenilalanina/DNA y el tamaño celular.

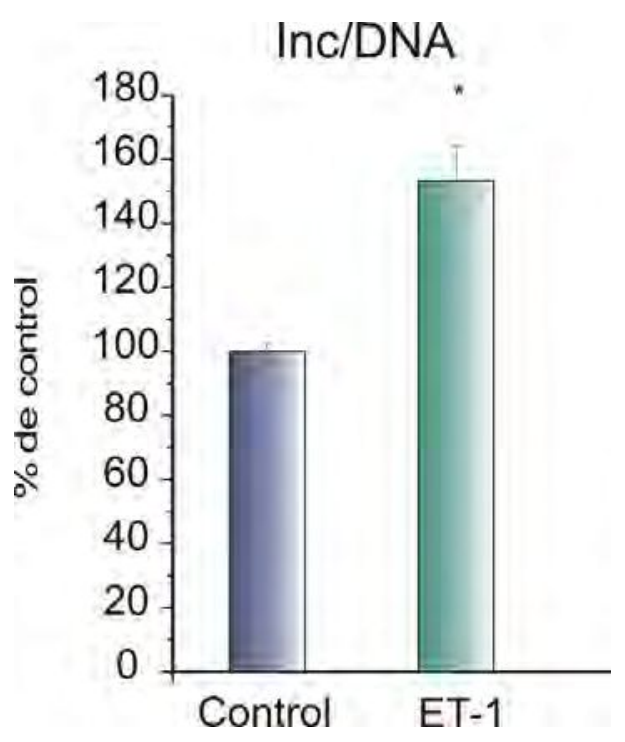

Figura 14: Incorporación de ${ }^{3} \mathrm{H}$ fenilalanina/DNA, resultados promedio expresados como \% respecto de control. La ET-1 exógena aumentó el valor de la incorporación 
de ${ }^{3} \mathrm{H}$ fenilalanina/DNA al $153 \pm 10.9 \%(n=14) .{ }^{*}=p<0.05$ vs. control, analizado por test de $\mathrm{t}$.
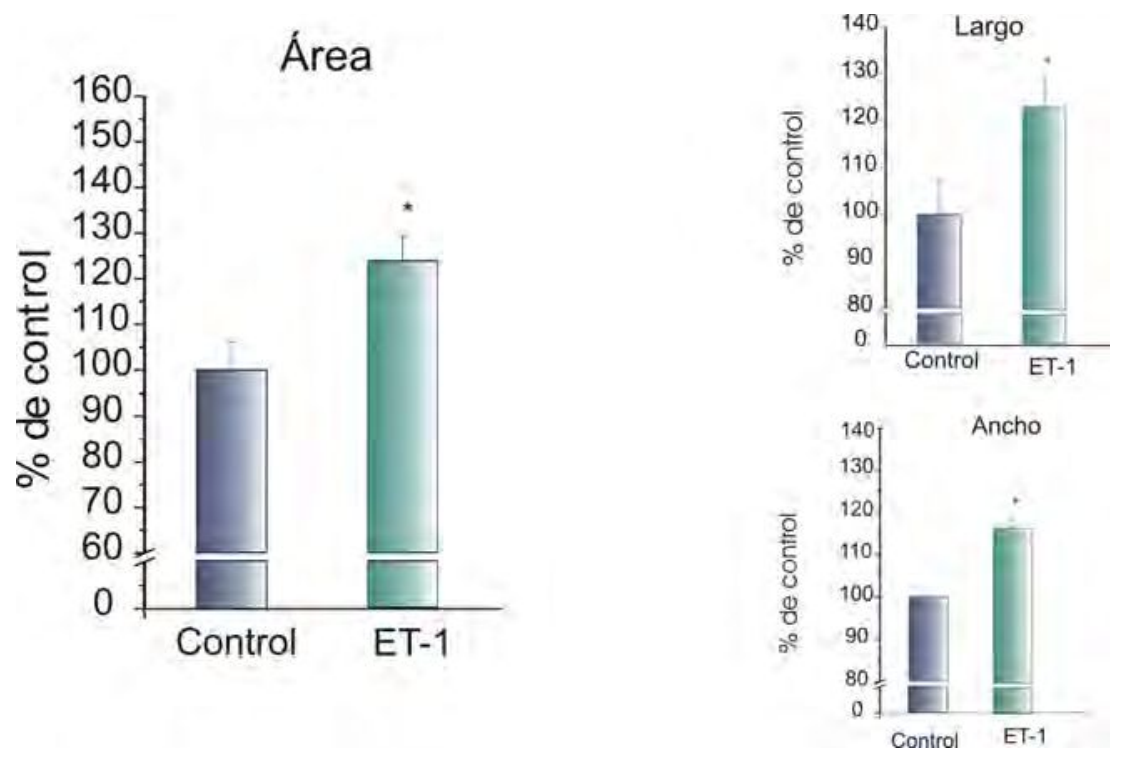

Figura 15: Resultados promedio del tamaño celular de $n=8$ para ET-1 expresados como \% respecto de control. La ET-1 exógena aumentó los valores de largo, ancho y área al $124 \pm 6.32 \%, 117 \pm 1.95 \%$ y $125 \pm 5.4 \%$, respectivamente. ${ }^{*}=p<0.05$ vs. control, analizado por test de t.

Participación del NHE-1 en el efecto hipertrofiante de la ET-1:

Una vez que se evidenció que el efecto hipertrofiante de la Ang II estaba mediado, en nuestra situación experimental, por ET-1 endógena se evaluó si el NHE-1 estaba involucrado en dicho efecto hipertrofiante. La Ang II y la ET-1 son agonistas de receptores acoplados a proteína $G$ que son conocidos activadores del NHE-1. Se repitieron los cultivos de miocitos en presencia de ET-1 más un bloqueante específico del NHE-1, el HOE 642. Se evaluó el efecto del HOE 642 a nivel de la incorporación de ${ }^{3} \mathrm{H}$ fenilalanina/DNA y el tamaño 
celular (largo, ancho y área). Como se muestra en la figura 16 el bloqueante específico del NHE-1 canceló el efecto hipertrofiante de ET-1. El valor de la incorporación de ${ }^{3} \mathrm{H}$ fenilalanina/DNA de las células tratadas con ET-1+HOE 642 fue de $87 \pm 21 \%$ ( $n=6)$.

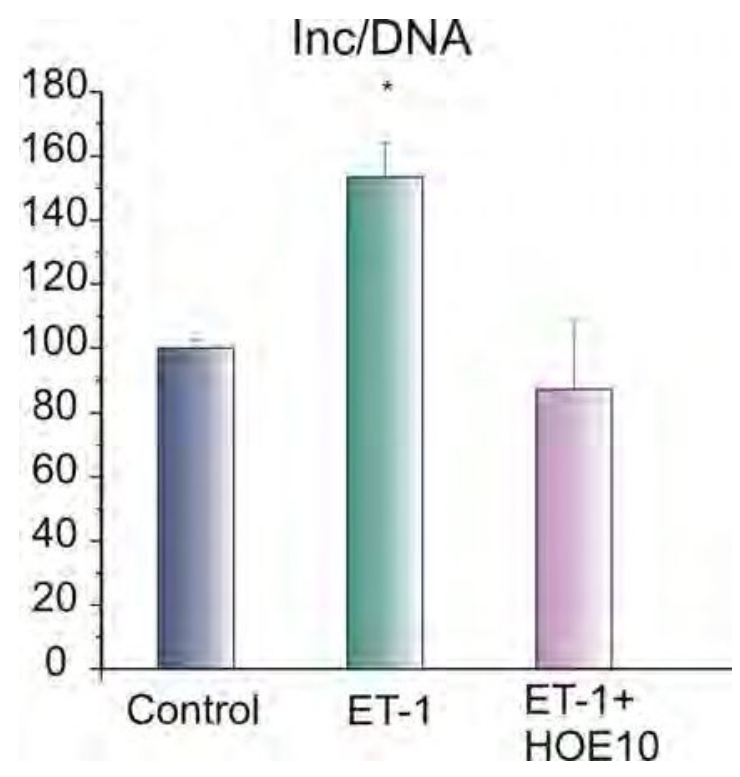

Figura 16: Incorporación de ${ }^{3} \mathrm{H}$ fenilalanina/DNA, resultados promedio de $\mathrm{n}=14 .{ }^{*}=\mathrm{p}<$ 0.05 vs. control, analizado por ANOVA.

Cuando se evaluó el tamaño celular, se evidenció que el efecto hipertrofiante de ET-1 fue cancelado por HOE 642 ya que los cardiomiocitos tratados con ET$1+$ HOE 642 no aumentaron el valor de su largo $(85 \pm 7.2 \%)$, ni el valor de su ancho $(96 \pm 5.3 \%)$ ni el valor de su área $(81 \pm 8.8 \%)$ como se muestra en la figura 17 ( $n=8$ para cada parámetro). Estos valores, ligeramente diferentes al valor control, no fueron estadísticamente significativos. 

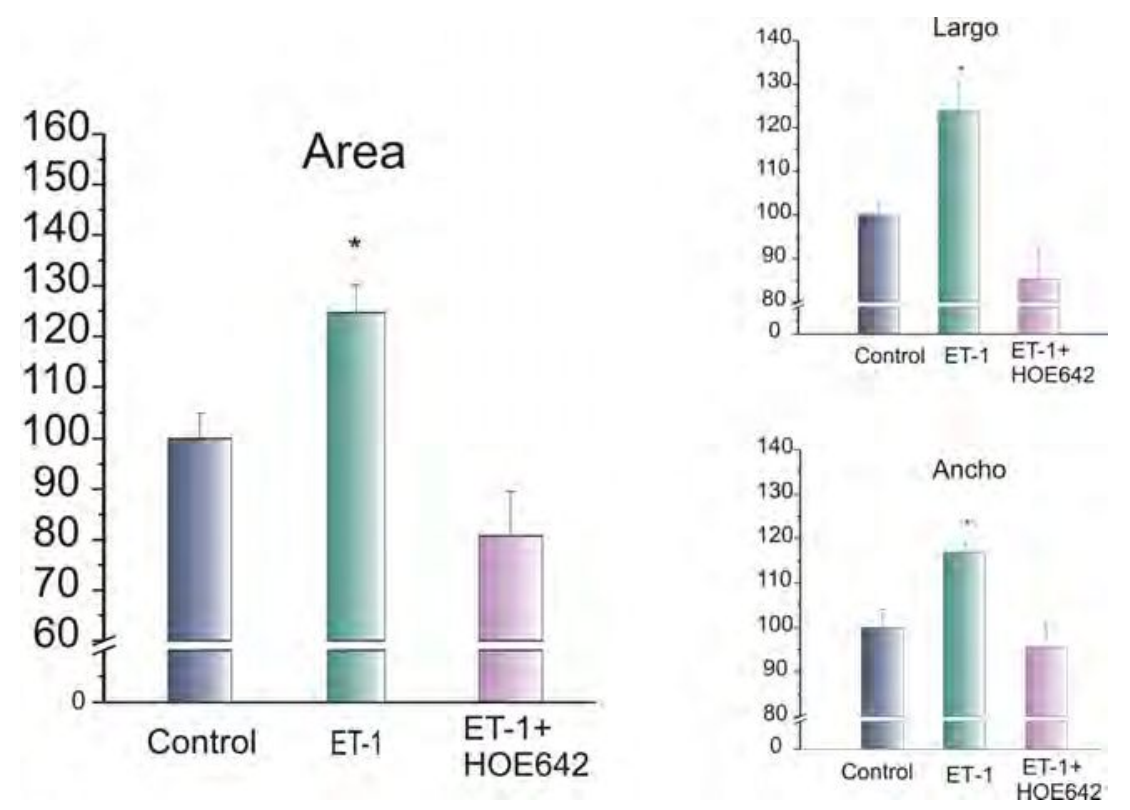

Figura 17: Resultados promedio del tamaño celular de $n=8$ expresados como $\%$ respecto de control. ${ }^{*}=p<0.05$ vs. control, analizado por ANOVA.

Participación del NHE-1 en la expresión del ARN $\mathrm{m}_{\mathrm{m}}$ de ANF mediada por ET-1:

La participación del NHE-1 como eslabón necesario en la vía de señalización intracelular que conduce al desarrollo de HC estimulada por ET-1 también se investigó a nivel de la expresión de uno de los marcadores moleculares de HC, el ANF. Para ello se cultivaron células, con el mismo protocolo experimental antes mencionado, en presencia de ET-1 y de EMD 87580 que es otro inhibidor del NHE-1. La ET-1 produjo un aumento en la abundancia del $A R N_{m}$ de ANF $(144 \pm 15.2 \%, n=5)$ que fue cancelado en presencia del bloqueante del NHE-1 $(81 \pm 8.2, n=6)$, como se muestra en la figura 18 . 


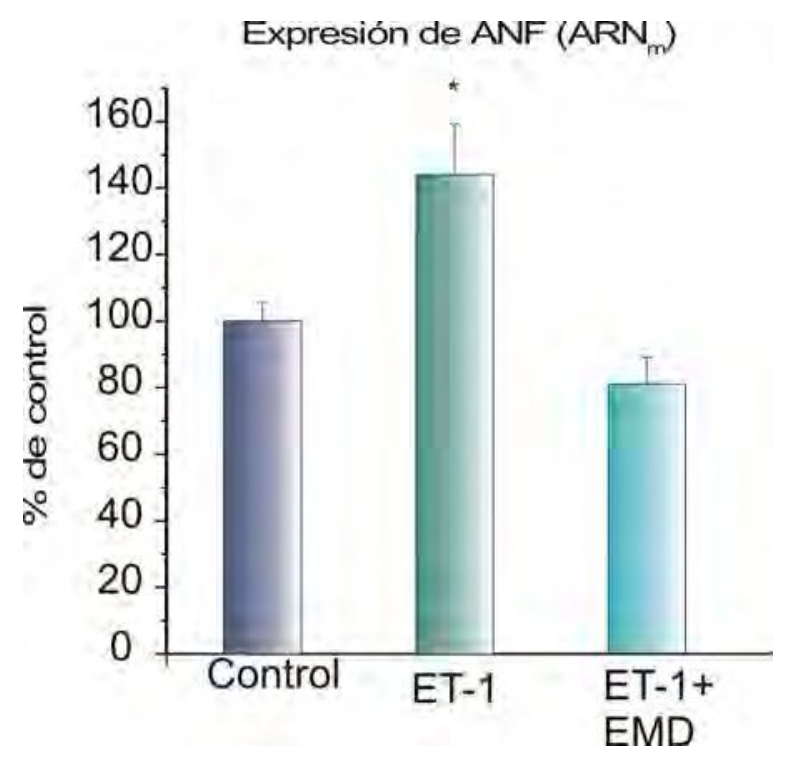

Figura 18: Promedio de la expresión del RNAm de ANP como marcador de hipertrofia (\% respecto de control). ${ }^{*}=p<0.05$ vs. control, analizado por ANOVA.

Participación de la ET-1 en la producción de ERO estimulada por Ang II:

Dado que se ha sugerido el papel hipertrofiante de las ERO y su acción como segundos mensajeros intracelulares, se evaluó si la respuesta hipertrófica desencadenada por Ang II involucraba un incremento de la producción de ERO. Para este fin, se investigó si la Ang II en concentración $1 \mathrm{nmol} / \mathrm{L}$ era capaz de producir un aumento en la producción de ERO. Para ello se midió la epifluorescencia del indicador $\mathrm{H}_{2}$ DCFDA desesterificado de miocitos incubados con el mismo, marcapaseados a $0.5 \mathrm{~Hz}$ tratados con Ang II y con losartán. Además se evaluó si la ET-1 estaba involucrada en la producción de ERO inducida Ang II, para ello se bloquearon ambos tipos de receptores ( $\mathrm{A}$ y $B$ ) de la ET-1 con TAK 044 antes de la administración de Ang II. La Ang II indujo un 
aumento en la producción de ERO que se canceló en presencia del bloqueante de los receptores $A T_{1}$, losartán y más interesante aún, también cuando se bloquearon los receptores de ET-1 con TAK 044 (bloqueante inespecífico de receptores de $\mathrm{ET}-1$ ) o con $\mathrm{BQ} 123$ (bloqueante específico de receptores $\mathrm{ET}_{\mathrm{A}}$ ). Como era de esperarse, el MPG también previno el aumento en la acumulación de ERO. La figura 19 muestra registros típicos de fluorescencia en función del tiempo y la figura 20 resume los valores promedio de cada grupo experimental. Estos resultados sugieren que la producción de ERO incrementada luego de la administración de Ang Il es el resultado de la liberación de ET-1 tras el estímulo de los receptores $\mathrm{AT}_{1}$.

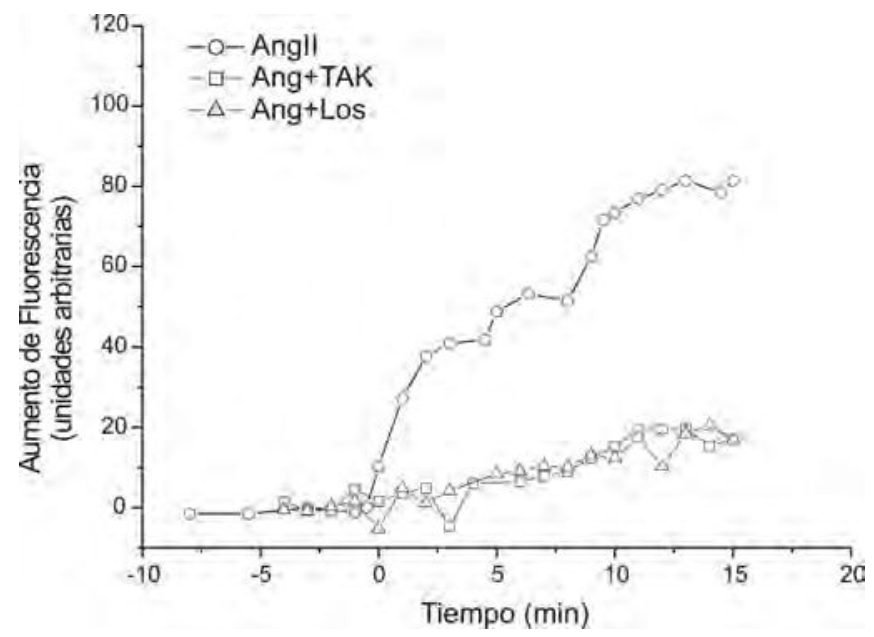

Figura 19: Aumento de ERO inducido por Ang II e inhibición del mismo por Ang II +TAK 044 y por Ang II+losartán. 


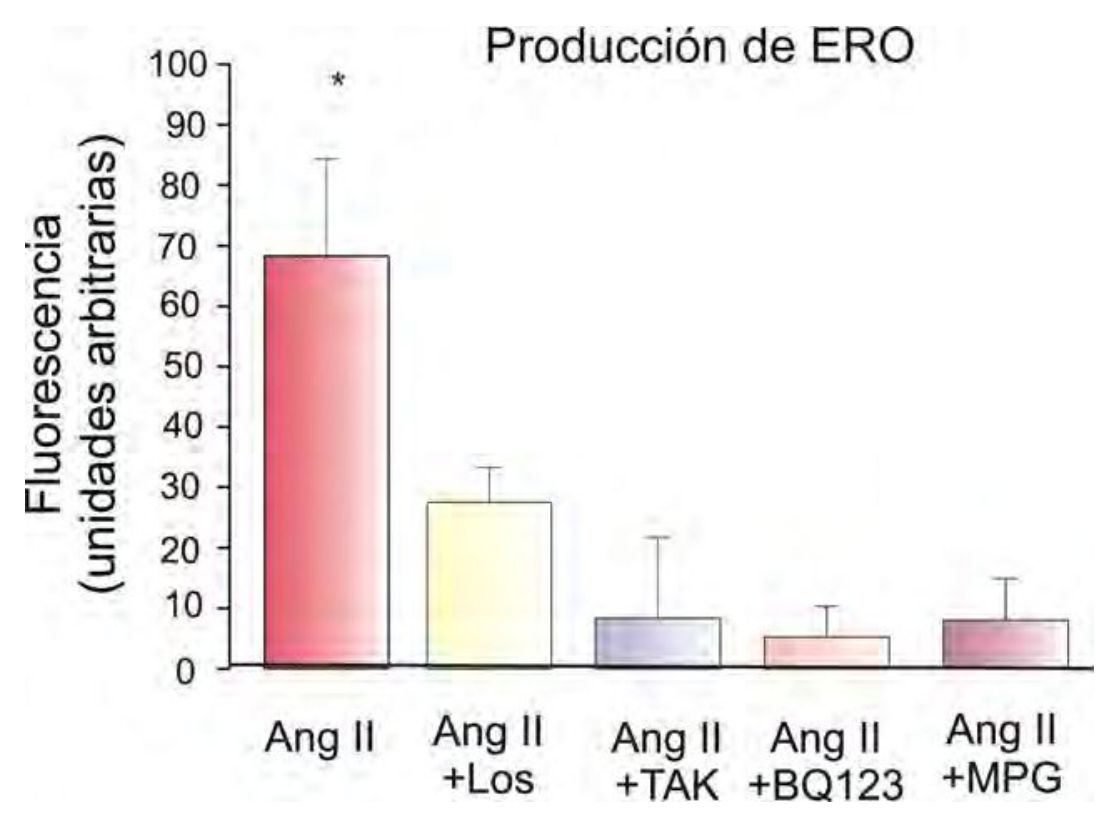

Figura 20: Disminución del aumento de ERO por losartán, TAK 044, BQ 123 y MPG * $p<0.05$ vs. control $(n=8)$, analizado por ANOVA.

Participación de las ERO en el efecto hipertrofiante de ET-1:

Los resultados experimentales antes expuestos evidencian que el efecto hipertrofiante de la Ang II se produce a través de ET-1 y que el NHE-1 representa un eslabón necesario en dicho proceso ya que su inhibición cancela el desarrollo de HC. Por otra parte, se evidenció que la Ang II por medio de la ET-1 induce un aumento en la producción de ERO.

Como antes se mencionara, experimentos de Sabri y col. (145) muestran que las ERO estimulan al NHE-1 a través de la activación de quinasas, es posible especular que la Ang II/ET-1 induce la formación de ERO que al activar dichas quinasas, estimulan al NHE-1. Con el fin de evaluar la participación de las ERO en el efecto hipertrofiante de ET-1, se cultivaron cardiomiocitos aislados 
siguiendo el mismo protocolo experimental, en presencia y ausencia de ET-1 y de un agente capturador de ERO, el MPG. Los resultados de estos experimentos se muestran en las figuras 21,22 y 23 en donde el aumento de la incorporación de ${ }^{3} \mathrm{H}$ fenilalanina/DNA, del tamaño celular (largo, ancho y área) y de la expresión de ANF de las células tratadas con ET-1 fue cancelado cuando se cultivaron con ET-1 en presencia de MPG.

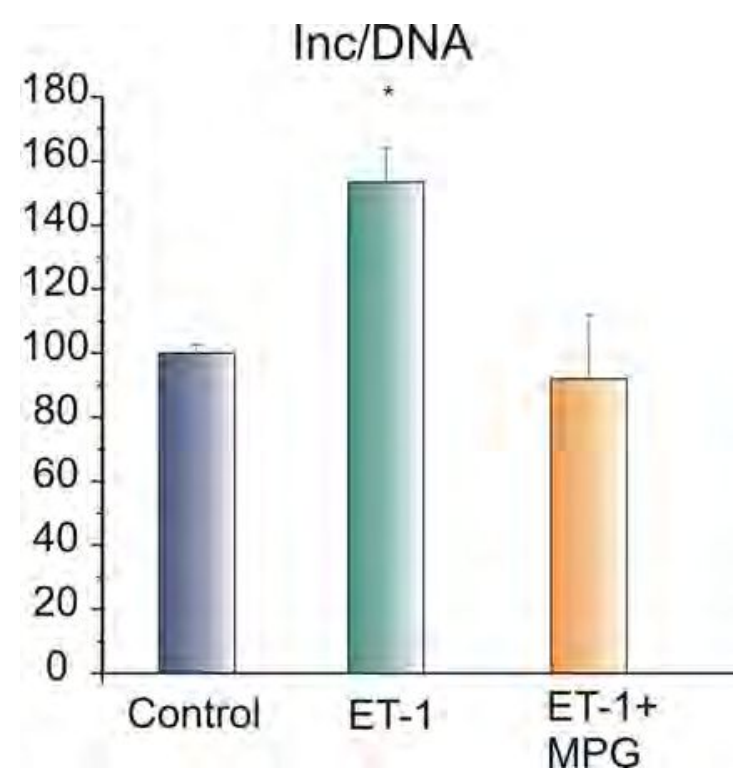

Figura 21: Incorporación de ${ }^{3 \mathrm{H}}$ fenilalanina/DNA, cuyo valor fue de $92 \% \pm 19.8$ resultados promedio de $n=8$. * significa distinto de control, $p<0.05$, analizado por ANOVA. 


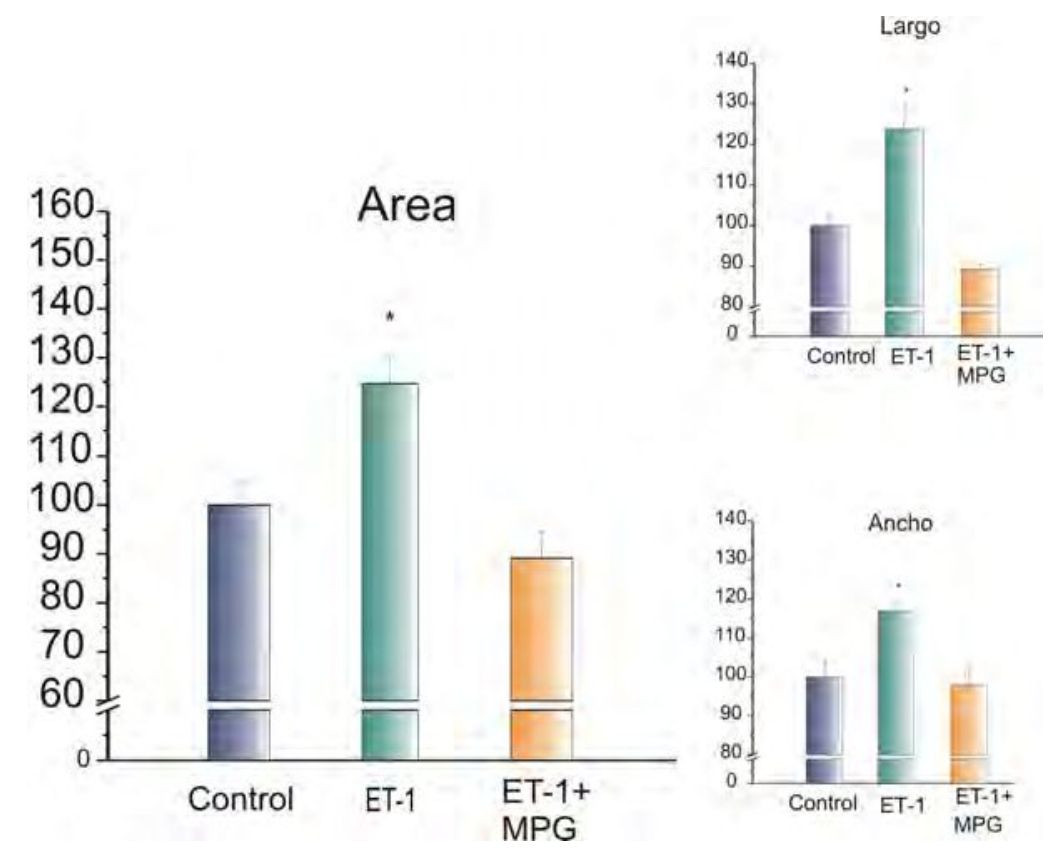

Figura 22: Resultados promedio del tamaño celular de $n=8$ expresados como $\%$ respecto de control. El valor del largo fue de $89 \pm 1.1 \%$, el valor del ancho fue de $98 \pm$ 4.4 y el valor del área fue de $89 \pm 5.4 \%$. ${ }^{*}=p<0.05$ vs. Control, analizado por ANOVA.

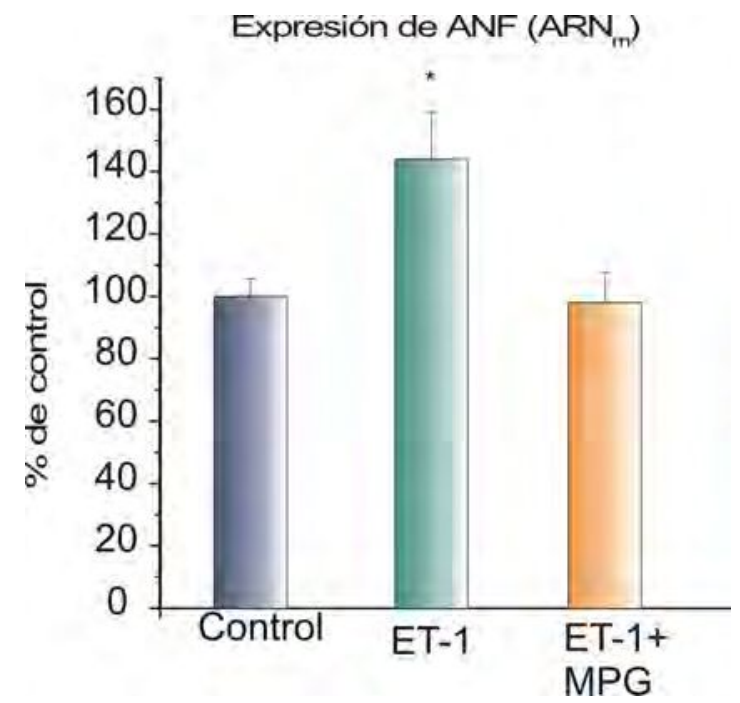

Figura 23: Promedio de la expresión del RNAm de ANP como marcador de hipertrofia (\% respecto de control) $145 \pm 15.2 \% n=8, p<0.05)$ y $98 \pm 9.6(n=5)$ para ET-1 y ET-1 + MPG, respectivamente. ${ }^{*}=p<0.05$ vs. Control, analizado por ANOVA. 
Participación de las MAPK en el efecto hipertrofiante de ET-1:

Se mencionó anteriormente que la liberación de ERO activa la vía ERK 1/2-p90 RSK y esta vía a su vez sería la que activa al NHE-1 (145). A fin de corroborar esta cascada de eventos en nuestras condiciones experimentales, se analizó el efecto de ET-1 sobre la fosforilación de ERK $1 / 2$ y de p90RSK. También se analizó la participación de las ERO en la activación de dicha vía.

En las células tratadas con ET-1 se detectó un aumento de la fosforilación de ERK $1 / 2$ al $145 \pm 9.4 \%(n=8 p<0.05)$ y de p90RSK al $136 \pm 8.5 \%(n=6, p<$ 0.05) respecto de la situación control que se consideró $100 \%$.

Este aumento de la fosforilación de ERK $1 / 2$ y de p90RSK por ET-1, no se produjo en las células tratadas con ET-1 + MPG $(102 \pm 4.8 \% n=4$ y $103 \pm 5.5$ $\% \mathrm{n}=5$ respectivamente) como se observa en la figura 24 .

p-ERK $1 / 2$

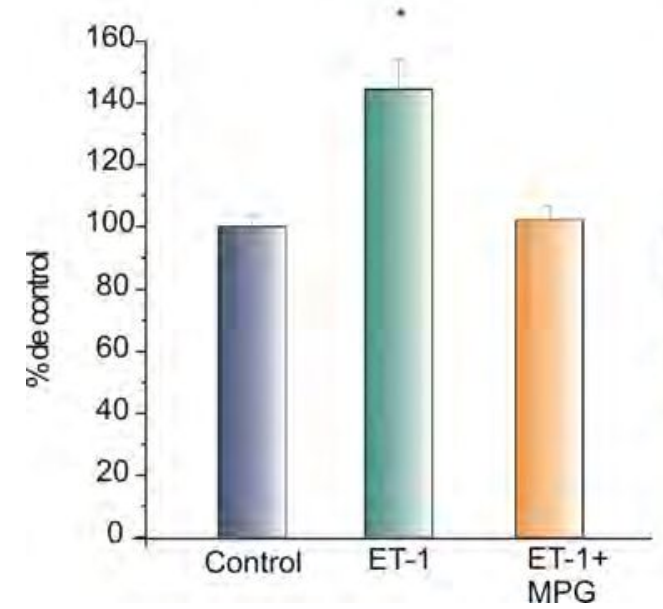

p-90 RSK

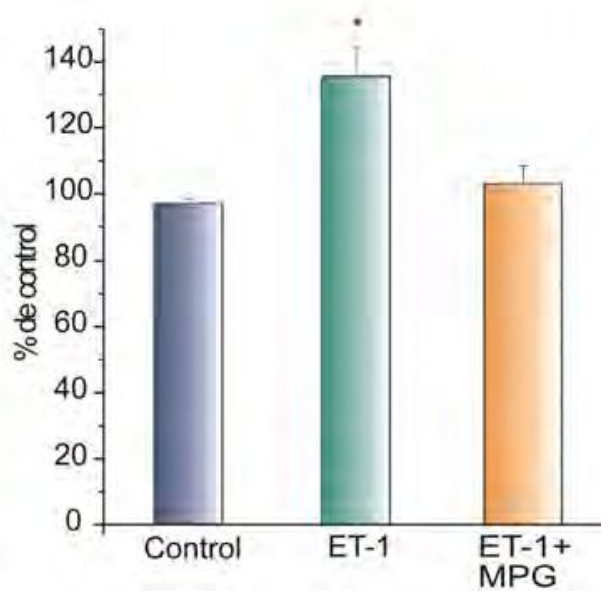

Figura 24: Promedio de la fosforilación de ERK $1 / 2$ y p90RSK (\% respecto de control). * $=p<0.05$ vs. control, analizado por ANOVA. 


\section{DISCUSIÓN:}

Este trabajo de Tesis Doctoral presenta y analiza los resultados obtenidos luego de exponer cultivos de miocitos cardíacos aislados de corazones de gatos adultos, a Ang II o ET-1 en lo que respecta a sus efectos sobre la HC. Los mismos muestran los siguientes aportes:

1. La Ang II en concentraciones relativamente bajas $(1 \mathrm{nmol} / \mathrm{L})$, posee un efecto hipertrofiante enteramente debido a la ET-1 endógena liberada tras el estímulo de los receptores $\mathrm{AT}_{1}$.

2. El efecto prohipertrófico de la ET-1 endógena se produce por la estimulación de sus receptores $\mathrm{ET}_{\mathrm{A}}$.

3. El mecanismo Ang II/ET-1 antes mencionado lleva al aumento de la producción de ERO que parecen ser un eslabón importante de la vía de señalización intracelular prohipertrófica desencadenada por Ang II/ET-1 ya que el desarrollo de $\mathrm{HC}$ se cancela en presencia del capturador de ERO, MPG.

4. El NHE-1 posee un papel clave en la cascada de eventos intracelulares que desencadenan la HC ya que la inhibición específica del NHE-1 previene el desarrollo de $\mathrm{HC}$.

5. La ET-1 aumenta la fosforilación de ERK 1/2- p90 RSK, que conduciría a la fosforilación e hiperactividad del NHE-1. Este efecto es inhibido por 
MPG lo que avala la participación de las ERO en el efecto hipertrofiante de ET-1.

\section{Liberación de ET-1 por Ang II:}

Numerosas investigaciones apoyan la noción de que varios de los efectos originalmente atribuidos a la acción de la Ang II estarían mediados en realidad por la ET-1 endógena. En tal sentido se ha demostrado que la administración de Ang II estimula la expresión del $A R N_{m}$ de preproendotelina y la liberación ET en diversas células incluidos los miocitos cardíacos (158-161). Por otra parte, los efectos de Ang II enteramente mediados por ET-1 ocurrirían cuando la concentración de Ang II es pequeña (del orden nanomolar o inferior) (158). Se ha comprobado que el bloqueo de los receptores de ET evita numerosos efectos atribuidos a Ang II tales como el desarrollo de hipertensión arterial provocada por su administración crónica (162), la activación del NHE (58) y del intercambiador $\mathrm{Cl} / / \mathrm{HCO}_{3}-\mathrm{Na}^{+}$independiente (163).

Formación de ERO por Ang II

Las NADPH Oxidasas como fuente de ERO 
La actividad de la NADPH oxidasa es de particular importancia en la fisiopatología cardíaca, dicha actividad puede ser aumentada significativamente por varios estímulos que son relevantes para el desarrollo de $\mathrm{HC}$ e insuficiencia cardíaca, por ejemplo, el estiramiento cíclico de cardiomiocitos(164,165), la Ang II (166-168), agonistas a-adrenérgicos (169), ET-1 (170) y TNF- $\alpha$ $(171,172)$, que actúan tanto a través de la modificación post-traduccional de las subunidades regulatorias como de las vías de transcripción. Curiosamente, varios estudios han demostrado que el $\mathrm{O}_{2}$ - producido por la $\mathrm{NADPH}$ oxidasa puede servir para promover una mayor generación de ERO desde otras fuentes. Por ejemplo, el $\mathrm{O}_{2}$ - producido por NADPH oxidasa puede oxidar y degradar a la tetrahidrobiopterina $\left(\mathrm{BH}_{4}\right)$, que es un co-factor de la enzima NOS, lo que llevaría al desacople de las subunidades de la misma. Este mecanismo se ha demostrado en ratones ApoE deficientes con hipertensión experimental $(173,174)$. Del mismo modo, el $\mathrm{O}_{2}$-derivado de la NADPH oxidasa también puede activar a la XO (175). Por lo tanto, las NADPH oxidasas pueden ser fundamentales incluso en entornos en los que parte del estrés oxidativo proviene de otras enzimas.

La familia de enzimas NADPH oxidasa es la principal fuente de $\mathrm{O}_{2}$ - en el sistema cardiovascular (176-178). De hecho, las NADPH oxidasas son las únicas enzimas cuya función principal hasta la fecha, parece ser la producción de $\mathrm{O}_{2}$ - (179). Cada miembro de la familia de las NADPH oxidasas contiene una unidad catalítica denominada NOX que forma un heterodímero con una 


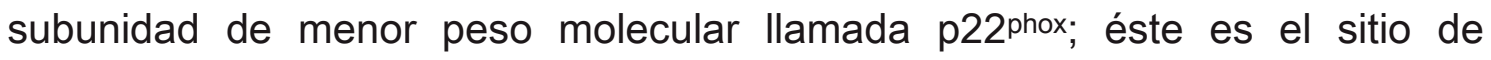
transferencia de electrones de la NADPH al $\mathrm{O}_{2}$ molecular, lo que resulta en la formación de $\mathrm{O}_{2}$ - Cinco isoformas de la NOX (NOX1-5) han sido identificadas hasta la fecha, cada una codificada por un gen distinto (179). Es interesante señalar que la regulación bioquímica de las diferentes NOX varía de forma significativa. En particular, NOX1 y NOX2 requieren ambas la asociación de las subunidades citosólicas (es decir, p47phox, p67phox, p40phox y Rac, o isoformas del mismo) con el citocromo a fin de activar la producción de $\mathrm{O}_{2}^{-}$(179). En contraste, la activación de NOX4 no parece exigir estas subunidades citosólicas (180-182)

Las células cardiovasculares exhiben patrones específicos de expresión de NOX, distintos tipos de células pueden expresar más de una isoforma. NOX1 es altamente expresada en células de músculo liso vascular, pero no es significativamente expresada en cardiomiocitos o células endoteliales $(178,179)$. NOX2 es abundante en cardiomiocitos, (169,183-185) células endoteliales (176) y fibroblastos (186-188). La isoforma NOX4 parece ser la más ampliamente expresada, se encuentra en células endoteliales $(183,189)$, cardiomiocitos $(184)$ y fibroblastos $(186,190)$.

La mitocondria como fuente de ERO. 
Las mitocondrias generan ERO durante su principal función intracelular que es la fosforilación oxidativa. Esto se ha atribuido a las fugas de electrones asociados con una reducción en la actividad de los complejos que componen la cadena de transporte de electrones siendo así una fuente de $\mathrm{O}_{2}^{-}, \mathrm{H}_{2} \mathrm{O}_{2}$, y $\mathrm{OH}^{-}$. Este estrés oxidativo juega un papel inicial en el deterioro del ADN mitocondrial y por ende la función de esta organela que puede resultar en anomalías en su potencial de membrana, fuga de ERO y daño celular. El exceso de ERO derivados de las mitocondrias es probable que contribuya a la insuficiencia cardíaca (191). Se ha descripto que la sobreexpresión del antioxidante mitocondrial, 3-peroxiredoxina, mejora el daño en el ADN mitocondrial e inhibe los efectos adversos de la remodelación del ventrículo izquierdo después del infarto de miocardio (192).

La formación de ERO dentro de la mitocondria después de la apertura de los canales de potasio mitocondriales dependientes de ATP (mK ATP) fue demostrada en varios estudios (193-198). Sin embargo, el mecanismo exacto por el cual este efecto se lleva a cabo no está claro. Andrukhiv y col. (199) han informado recientemente que un aumento del $\mathrm{pH}$ en la matriz mitocondrial inducido por una mayor entrada de $\mathrm{K}+$ a través de los $\mathrm{mK}_{\mathrm{ATP}}$ es el mecanismo responsable de este efecto. Estos autores también sugirieron que la apertura de los $\mathrm{mK}_{\text {ATP }}$ es inducida por la formación de $\mathrm{O}_{2}{ }^{-}$que se produce en el complejo I de la cadena de transporte de electrones (199). 
Activación de quinasas mediada por ERO:

Existen diferentes moléculas involucradas en la señalización celular que son sensibles a redox (reacciones de oxidación/reducción) y se ha demostrado que pueden ser activadas por las ERO derivadas de la NADPH oxidasa. Esto incluye a: RAS, c-src, MAPKs, $\mathrm{Pl}_{3}$ quinasa $\left(\mathrm{Pl}_{3} \mathrm{~K}\right)$ / Akt, NF-KB, AP-1, HIF-1 y otras (200-207). Xiao y col. (169) reportaron la activación de MEK 1/2, ERK 1/2 y p90RSK dependiente de las ERO en cardiomiocitos aislados en respuesta a la fenilefrina como estímulo hipertrofiante.

En cardiomiocitos de ratas neonatas, el $\mathrm{H}_{2} \mathrm{O}_{2}$ estimula la tirosina quinasa $\mathrm{Src}$, la GTPasa RAS, PKC, MAPK (ERK1/2), y Jun-NK $(145,208,209)$. Niveles bajos de $\mathrm{H}_{2} \mathrm{O}_{2}$ se asocian con la señal de activación de ERK1/2 y la síntesis de proteínas, mientras que niveles más altos estimulan señales que pueden inducir apoptosis (210). Las ERO también desempeñan un papel importante en el mecanismo de $\mathrm{HC}$ inducido por la activación de la estimulación de los receptores acoplados a proteína G como el receptor de Ang II o el $\alpha$ adrenérgico (200,211-214). Las ERO también estimulan la quinasa-1 de señalización de apoptosis celular (ASK-1), una quinasa que está por encima de Jun-KN y p38 en la cascada de señalización. La ASK-1 favorece la sobreexpresión NF-kB para estimular la HC, mientras que el bloqueo genético de la ASK-1 inhibe la hipertrofia inducida por Ang II, noradrenalina y ET-1 (215). 
La apoptosis de los cardiomiocitos es otra fuente importante que contribuye a la remodelación hipertrófica y la disfunción de las células (216). Por ejemplo, en un modelo en ratones que carecen de señalización de la ASK-1, se demostró que los mismos presentaron una reducción de la remodelación ventricular y de la apoptosis celular en respuesta a la carga de presión o después de un infarto de miocardio (217). La apoptosis celular es inhibida a niveles bajos de ERO, mientras que lo contrario ocurre con niveles mayores (210). Las ERO también tienen efectos potentes en la matriz extracelular ya que estimulan la proliferación de fibroblastos cardíacos (218) y la activación de MMPs (219-221) cuyos efectos son centrales en la fibrosis y la remodelación de la matriz extracelular. Las MMPs son secretadas en general en una forma inactiva y se activan postranscripcionalmente por interacciones específicas de las ERO con los residuos de cisteína del dominio autoinhibitorio del propéptido (222). Las ERO mediante la estimulación de factores de transcripción como el NF-kB y el AP-1, pueden inducir la expresión de las MMP (220).

\section{NHE-1 e Hipertrofia Cardíaca.}

Como se describió anteriormente, el NHE-1 es una glicoproteína integral de membrana de distribución ubicua que posibilita el intercambio electroneutro de un $\mathrm{H}^{+}$intracelular por un $\mathrm{Na}^{+}$extracelular (1:1), constituyendo uno de los principales mecanismos regulatorios del $\mathrm{pH}_{\mathrm{i}}(146)$. En él es posible distinguir un 
dominio transmembrana $\mathrm{N}$-terminal asociado al transporte iónico y una larga cola citoplasmática en su extremo C-terminal que está involucrada en la regulación de la actividad del intercambiador aparentemente mediante distintos mecanismos, siendo la fosforilación el mejor conocido de ellos (146). El NHE-1 presenta un grado de fosforilación basal y un aumento de la misma ocasiona un aumento de su actividad (86).

En el miocardio hipertrófico de las ratas SHR, el NHE-1 se encuentra hiperactivo $(42,43)$. El aumento de actividad del NHE-1 se debe a un aumento de la actividad intrínseca de las unidades funcionales preexistentes producido por modificaciones post-traduccionales de la proteína (fosforilación), sin cambios en sus niveles de expresión (223).

En el año 2000 fue publicado un trabajo en el que se describió por primera vez que la inhibición farmacológica del NHE-1 atenuaba la respuesta hipertrófica en el tejido cardíaco viable luego del infarto agudo de miocardio (224). Posteriormente Camilión de Hurtado y colaboradores (45) comunicaron un efecto similar sobre la $\mathrm{HC}$ de las ratas SHR. Es importante recalcar que la regresión de la HC inducida por inhibición farmacológica in vivo del NHE-1 ocurre en ausencia de un descenso de la presión arterial sistólica. En concordancia con estos hallazgos, el trabajo de Álvarez y col. (225) mostró que distintos tratamientos farmacológicos (inhibición de la ECA, bloqueo de los receptores $\mathrm{AT}_{1}$ y bloqueo de los canales de $\mathrm{Ca}^{+2}$ ), provocan regresión de la $\mathrm{HC}$ en ratas SHR, en una magnitud que no tiene una relación proporcional con los 
niveles de presión arterial sistólica alcanzados. Además, en todos estos casos la regresión de la $\mathrm{HC}$ se acompañó de la normalización de la actividad del NHE-1 en el miocardio. El efecto antihipertrófico del bloqueo del NHE-1 fue descripto posteriormente en una variedad de modelos experimentales de $\mathrm{HC}$ patológica diferentes, tales como el inducido por aldosterona, (226) por hipertiroidismo, (227) por infusión de monocrotalina, (228) por sobrecarga combinada de presión y volumen (229), en ratones deficientes en el receptor de ANP, (38) y en la miocardiopatía hereditaria en hámsteres (230). Si bien actualmente este efecto se encuentra sólidamente demostrado, aún no se conoce con precisión el mecanismo por el cual ocurre. Se ha propuesto a la disminución del influjo de $\mathrm{Na}^{+}$como un posible responsable. Los resultados obtenidos en el modelo de miocardiopatía hereditaria en hámsteres y en el modelo de $\mathrm{HC}$ por sobrecarga combinada de presión y volumen ya mencionados, también apoyan la hipótesis de que el NHE-1 participa en la HC modulando los niveles de la concentración de $\mathrm{Na}^{+}$intracelular $\left(\left[\mathrm{Na}^{+}\right]_{\mathrm{i}}\right)$ $(229,230)$. Cabe destacar que la mayor actividad del NHE-1 no provoca, en condiciones fisiológicas, un cambio en el $\mathrm{pH}_{\mathrm{i}}$ debido a que en la célula existe otro mecanismo, el intercambiador $\mathrm{Cl} / / \mathrm{HCO}_{3}{ }^{-}$independiente de $\mathrm{Na}^{+}(\mathrm{AE})$, que es acidificante y compensa la activación del NHE-1 (58). Un aumento en la $\left[\mathrm{Na}^{+}\right]_{i}$ ocasionado por hiperactividad del NHE-1 favorecería una mayor entrada de $\mathrm{Ca}^{+2}$ a través del NCX actuando en su modo inverso. Este incremento en la concentración de $\left[\mathrm{Ca}^{+2}\right]$ j jugaría un papel clave favoreciendo el crecimiento 
cardíaco al estimular las cascadas de señalización dependientes de $\mathrm{Ca}^{+2}$. Además, el aumento de la $\left[\mathrm{Na}^{+}\right]_{i}$ podría inducir el desarrollo de $\mathrm{HC}$ a través de la activación de ciertas isoformas de PKC (231).

$\underline{\mathrm{Na}^{+}}{ }_{i}$ e Hipertrofia Cardíaca, el papel del NCX

EI NCX es una proteína integral de membrana que promueve el transporte de 3 iones $\mathrm{Na}^{+}$por cada $\mathrm{Ca}^{+2}$ en direcciones opuestas generando el flujo de una carga neta positiva en cada ciclo, siendo entonces un transportador electrogénico. EI NCX está en la membrana plasmática de gran parte de las células de los mamíferos, contribuyendo a mantener la homeostasis del $\mathrm{Ca}^{+2}$. Se han encontrado 3 isoformas derivadas de 3 genes diferentes: NCX1 o tipo cardíaco, NCX2 o tipo muscular esquelético y NCX3 o tipo cerebral (232). El NCX1 es el más ampliamente distribuido, aunque abunda más en tejido cardíaco y cerebral $(233,234)$.

La expresión del NCX1 ocurre en etapas muy tempranas de la cardiogénesis (235), siendo máxima cerca del nacimiento en mamíferos normales (152) cayendo luego en la vida postnatal, proceso opuesto al que ocurre con otra proteína vinculada al manejo del $\mathrm{Ca}^{2+}$, la SERCA cuya expresión aumenta durante la vida postnatal $(154,155,236)$. Así, en los corazones de los recién nacidos, la participación del NCX en el acoplamiento éxito-contráctil cardíaco sería más relevante que en los corazones adultos. 
El NCX1 tiene 970 aa y un peso molecular de $110 \mathrm{KDa}$ (233). Posee 9 segmentos transmembrana, con la porción $\mathrm{N}$-terminal por fuera de la célula, mientras que el extremo C-terminal se encuentra hacia el citoplasma (figura 25) (237-239). Posee además un gran lazo interno hidrofílico (entre los aa 250 y 796) entre los segmentos transmembrana 5 y 6 , el cual es importante para la regulación alostérica intracelular por $\mathrm{Ca}^{+2} \circ \mathrm{Na}^{+}(240,241)$.

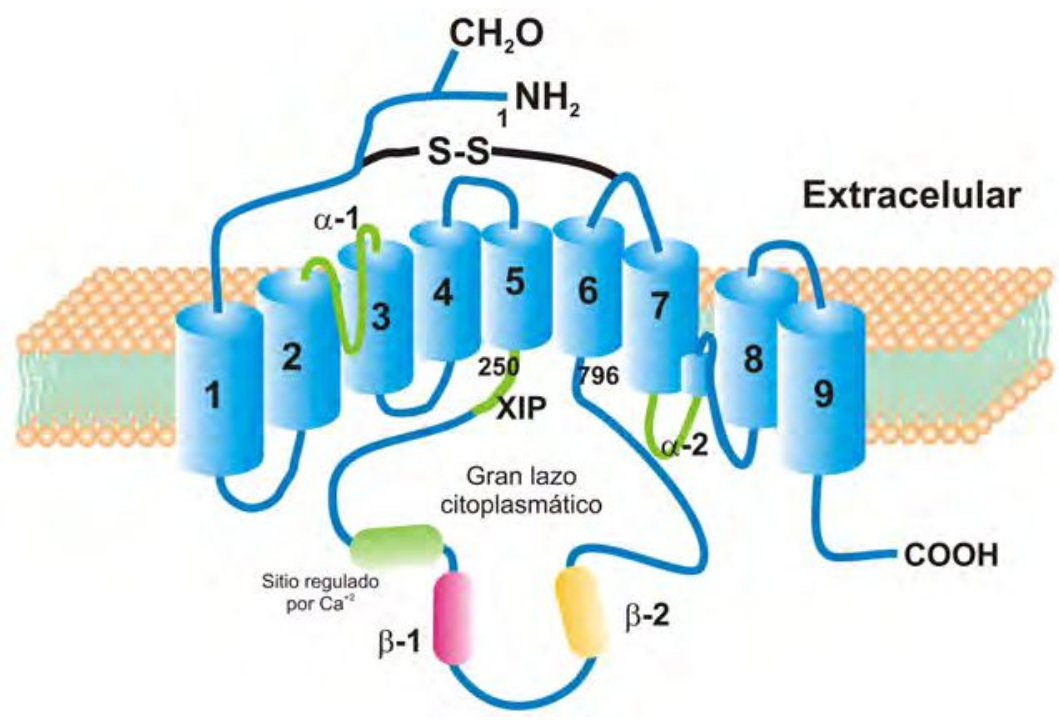

Figura 25: Representación esquemática del NCX.

La función primaria del NCX es el manejo de $\mathrm{Ca}^{+{ }_{i}}$. Bajo condiciones fisiológicas y suponiendo que los gradientes de $\mathrm{Na}^{+}$y $\mathrm{Ca}^{+2}$ permanecen constantes en el espacio subsarcolemal, podemos estimar que el potencial de inversión del $\mathrm{NCX}\left(E_{\mathrm{NCX}}\right)$ (valor del potencial de membrana que anula el flujo iónico por gradiente de concentraciones a través del intercambiador), es aproximadamente $-40 \mathrm{mV}$ que surge de la siguiente ecuación: 


$$
\begin{gathered}
\mathrm{E}_{\mathrm{NCX}}=3 \mathrm{E}_{\mathrm{Na}}-2 \mathrm{E}_{\mathrm{Ca}} \\
\mathrm{E}_{\mathrm{Na}}=(\mathrm{RT} / \mathrm{F}) \ln \left\{\left[\mathrm{Na}^{+}\right]_{\mathrm{e}} /\left[\mathrm{Na}^{+}\right]_{\mathrm{i}}\right\} \quad(\text { ecuación 1) } \\
\mathrm{E}_{\mathrm{Ca}}=(\mathrm{RT} / 2 \mathrm{~F}) \ln \left\{\left[\mathrm{Ca}^{+2}\right]_{\mathrm{e}} /\left[\mathrm{Ca}^{+2}\right]_{\mathrm{i}}\right\}
\end{gathered}
$$

donde los símbolos entre corchetes indican concentración del ión, pudiendo ser intracelular (i) o extracelular (e), $\mathrm{E}_{\mathrm{Na}}$ y $\mathrm{E}_{\mathrm{Ca}}$ son los potenciales de equilibrio para el $\mathrm{Na}^{+}$y $\mathrm{Ca}^{+2}$ respectivamente, $\mathrm{R}$ la constante de los gases, $\mathrm{T}$ la temperatura absoluta y F la constante de Faraday, considerándose como valores fisiológicos de $\left[\mathrm{Na}^{+}\right]_{i}$ y $\left[\mathrm{Na}^{+}\right]_{\mathrm{e}} 10$ y $140 \mathrm{mmol} / \mathrm{L}$ respectivamente.

Dado que se trata de un transportador electrogénico, la fuerza impulsora (FI) que actúa sobre el NCX está determinada por la diferencia entre el potencial de membrana $(\mathrm{Vm})$ y el $\mathrm{E}_{\mathrm{NCX}}\left(\mathrm{FI}=\mathrm{Vm}-\mathrm{E}_{\mathrm{NCX}}\right)$. Cuando el $\mathrm{Vm}$ es igual al $\mathrm{E}_{\mathrm{NCX}}$ no se registra corriente, pues la $\mathrm{FI}$ es cero. A Vm más negativos que el $E_{\mathrm{NCX}}$ se ve favorecida la salida de $\mathrm{Ca}^{+2}$ y entrada de $\mathrm{Na}^{+}$(modo directo o "forward", corriente catiónica hacia adentro o "inward") contribuyendo a la relajación de la célula muscular. Cuando el Vm toma valores más positivos que el $E_{N C X}$ se registran flujos de estos iones en sentidos opuestos, es decir modo inverso o "reverse", corriente catiónica hacia afuera o "outward". El hecho de que durante un potencial de acción miocárdico (PA) el Vm supere el valor teórico de $E_{\mathrm{NCX}}$ haría pensar que el modo inverso del $\operatorname{NCX}\left(\mathrm{NCX}_{\text {inv }}\right)$ participaría activamente en el ingreso de $\mathrm{Ca}^{+2}$ durante el acoplamiento éxito-contráctil. Sin embargo, existe gran controversia respecto de la contribución del $\mathrm{NCX}_{\text {inv }}$ a la contractilidad 
basal (241-245) debido a que durante el PA el nivel de $\mathrm{Ca}^{+2}$ aumenta, y esto modifica el $E_{\mathrm{NCX}}$ haciéndolo más positivo. De esta manera existe un compromiso entre el aumento del $E_{\mathrm{NCX}}$ y del Vm, probablemente impidiendo que dicho PA alcance o supere el $E_{N C X}$ real (ver ecuación de $E_{N C X}$ ). Sin embargo ha sido demostrado que bajo ciertas condiciones farmacológicas y/o patológicas, el modo inverso puede cobrar mayor relevancia para la función contráctil (153,246-249). En la insuficiencia cardíaca por ejemplo se encuentra aumentada la expresión del NCX, supuestamente como un mecanismo compensador para mantener la contractilidad ante la deficiente función del retículo sarcoplásmico (RS), lo que hace pensar que el NCX contribuiría a la entrada de $\mathrm{Ca}^{+2}$ al citosol y de esta manera mantendría la función contráctil $(247,248)$.

Como ya se dijo, la actividad del NCX es afectada por la concentración intracelular de los iones que transporta. Tanto el $\mathrm{Ca}^{+2}$ como el $\mathrm{Na}^{+}$modulan la actividad del NCX1 (250,251). Más aún, ambos modos del intercambiador sólo son activos cuando se encuentra $\mathrm{Ca}^{+2}$ unido al sitio intracelular de alta afinidad localizado en la parte central del gran lazo citoplasmático $(252,253)$. Aunque existe controversia, el valor de la constante de afinidad de este sitio $\left(\mathrm{K}_{1 / 2}\right)$ se encontraría entre 0.022 y $0.4 \mu \mathrm{mol} / \mathrm{L}$ (254). En presencia de $\mathrm{Ca}^{+2}$ e y de $\mathrm{Ca}^{+2}$ en el sitio regulatorio intracelular, altas concentraciones de $\mathrm{Na}^{+}$en la superficie citoplasmática activan rápidamente el transporte, seguido por una caída lenta hacia el estado estacionario (250). Esto se conoce como inactivación 
dependiente de $\mathrm{Na}^{+}$(255) y se ha sugerido que ocurre cuando el sitio de transporte está muy cargado con $\mathrm{Na}^{+}(250,255)$. La inactivación dependiente de $\mathrm{Na}^{+}$está modulada por una gran variedad de factores: es aumentada cuando aumentan los niveles de $\mathrm{H}^{+}$intracelulares (bajo $\left.\mathrm{pH}_{\mathrm{i}}\right)(249,256,257)$ y es atenuada por concentraciones $\mu$ molares de $\mathrm{Ca}^{+2}$, milimolares de ATP, o PIP2 $(249,258,259)$. Esta inactivación está ausente cuando la superficie intracelular es digerida parcialmente por una enzima proteolítica (240), sugiriendo que el lazo intracelular está involucrado en esta inactivación. Además, el tratamiento del NCX1 con distintos agentes reductores (ditiotreitol y $\mathrm{FeSO}_{3}$ ) produce un aumento de su actividad $(260,261)$ interpretándose como una atenuación de la inactivación dependiente de $\mathrm{Na}^{+}(262)$.

El aumento de $\mathrm{Na}^{+}$intracelular favorece la entrada de $\mathrm{Ca}^{+2}$ por el modo inverso y/o deprime su salida por el modo directo, produciéndose una acumulación intracelular de $\mathrm{Ca}^{+2}$ que, de mantenerse en forma prolongada, puede cargar el RS o aún tener efectos nocivos (248).

$\underline{\mathrm{Ca}^{2+}}{ }_{\mathrm{i}}$ y señales hipertrofiantes:

La mayoría de los estímulos que inducen $\mathrm{HC}$ maladaptativa en respuesta a una sobrecarga hemodinámica activan la vía de $\mathrm{Gq}$ y confluyen en el aumento de la $\left[\mathrm{Ca}^{+2}\right]_{i}$ activando las vías de señalización intracelular dependientes de este ión. El aumento de la $\left[\mathrm{Ca}^{+2}\right]_{i}$ es uno de los fenómenos más importantes en el 
desarrollo de la respuesta hipertrófica y esto se ha confirmado provocando el aumento de la [Ca+2]i por medio de agonistas cálcicos (263), de ionóforos de $\mathrm{Ca}^{+2}$ (264), o mediante la elevación del $\mathrm{Ca}^{+2}$ extracelular (265), induciéndose en todos estos casos hipertrofia en cardiomiocitos in vitro.

Tradicionalmente, el análisis de la señalización intracelular ha estado asociado a la acción de quinasas, como las MAPKs y la $\mathrm{PI}_{3} \mathrm{~K}$, entre otras. Sin embargo, las fosfatasas son también importantes factores de transducción de señales que regulan el crecimiento y las respuestas al estrés en una amplia variedad de tipos celulares. Una de estas fosfatasas es la fosfatasa de proteínas 2B (PP2B), calcineurina. Ante aumentos sostenidos en la $\left[\mathrm{Ca}^{+2}\right]_{\mathrm{i}}$ la calcineurina es activada por el complejo $\mathrm{Ca}^{+2} /$ calmodulina y desfosforila a miembros de la familia de factores de transcripción NFAT en el citosol, permitiendo que éstos se trasloquen al núcleo e interactúen cooperativamente con otros factores de transcripción como AP-1, GATA-4 y MEF-2 estimulando la transcripción génica (266-269) (Figura 26). 


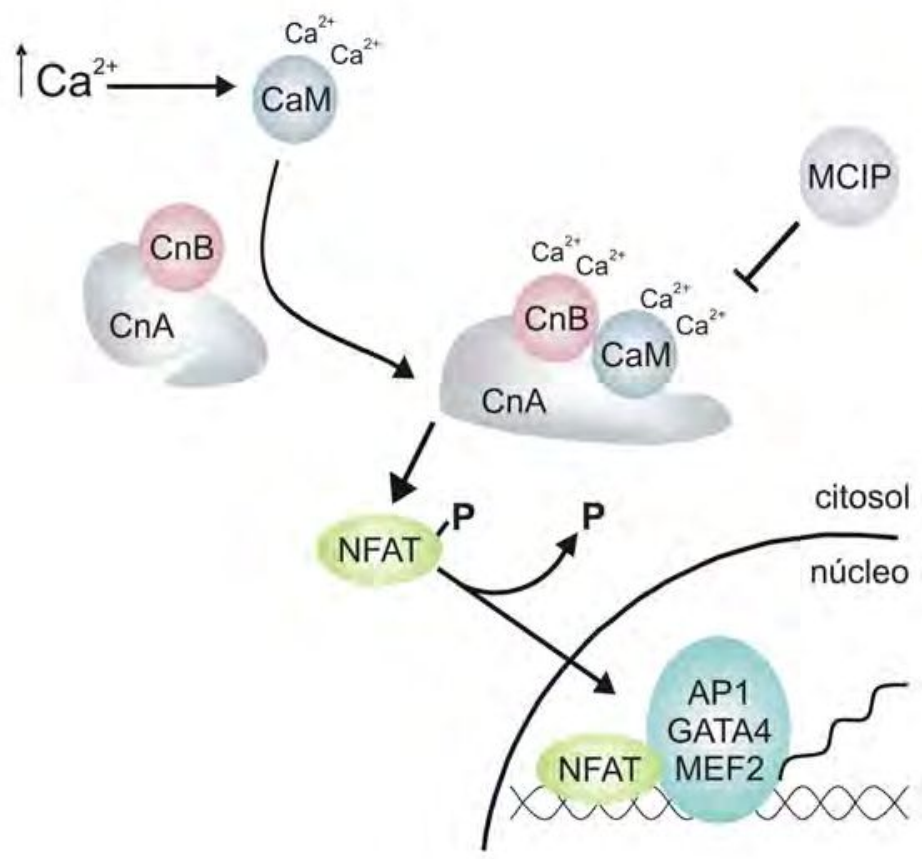

Figura 26: La calcineurina es activada mediante la unión de $\mathrm{Ca}^{+2}$ y CaM. La subunidad catalítica $(\mathrm{CnA})$ contiene un dominio $\mathrm{N}$-terminal catalítico y regiones de unión tanto para la subunidad regulatoria $B(\mathrm{CnB})$ como para CaM. El extremo C-terminal contiene un dominio autoinhibitorio que se pliega para ocluir el sitio activo cuando CaM no está unida. El aumento de la $\left[\mathrm{Ca}^{+2}\right]_{i}$ promueve la unión de $\mathrm{Ca}^{+2}$ a $\mathrm{CnB}$ y la del complejo $\mathrm{Ca}^{+2} /$ calmodulina a $\mathrm{CnA}$, desplazando el dominio autoinhibitorio. La desfosforilación de NFAT promueve su traslocación al núcleo, donde se une al DNA cooperativamente con otros factores de transcripción, entre los que se encuentran AP-1, GATA4, MEF2.

La activación de la calcineurina es una señal suficiente para inducir HC aunque posiblemente no estrictamente necesaria $(270,271)$. Su participación en el desarrollo de HC fue confirmado por las siguientes evidencias: a) ratones transgénicos que expresan una forma constitutivamente activa de calcineurina o de NFAT desarrollan HC (272), b) el tratamiento con inhibidores de la calcineurina como el FK506 y la ciclosporina (aunque con algunos resultados contradictorios en este último caso), induce la regresión o previene el desarrollo 
de $\mathrm{HC}$ en distintos modelos experimentales $(270,271,273-275)$, c) la actividad de calcineurina está aumentada en el miocardio hipertrófico de ratas SHR y de ratas con hipertensión arterial sensible a sal, y se normaliza al inducir farmacológicamente la regresión de la HC; (276-278) d) la sobre-expresión del inhibidor endógeno de la calcineurina, la MCIP1, inhibe la respuesta hipertrófica del miocardio $(279,280)$, e) ratones transgénicos deficientes en CnA (la isoforma de la subunidad catalítica de calcineurina que se relaciona directamente con su actividad) son incapaces de desarrollar HC ante una sobrecarga de presión, exposición a la Ang Il o infusión de isoproterenol (281).

\section{CONCLUSIÓN FINAL}

En el esquema que se presenta en la figura 27 se resume la cascada de eventos que se propone a partir de los datos experimentales antes expuestos. Estos sugieren que la Ang II estimula la liberación de ET-1 endógena que a su vez ocasiona un aumento en la producción de ERO, que conducen a la activación de ERK 1/2. Ésta última fosforila a p90RSK que activa al NHE-1 por fosforilarlo posiblemente en la serina ubicada en la posición 703 de la cola citosólica del intercambiador. La hiperactividad del NHE-1 aumenta la $\left[\mathrm{Na}^{+}\right]_{\mathrm{i}}$ favoreciendo que el NCX actúe en su modo inverso extruyendo $\mathrm{Na}^{+}$al intercambiarlo por $\mathrm{Ca}^{+2}$, entonces esto hace que aumente la $\left[\mathrm{Ca}^{+2}\right]_{i} \mathrm{y}$ desencadene efectos hipertrofiantes. Las flechas a la derecha muestran los inhibidores farmacológicos utilizados que permiten arribar a estas conclusiones. 


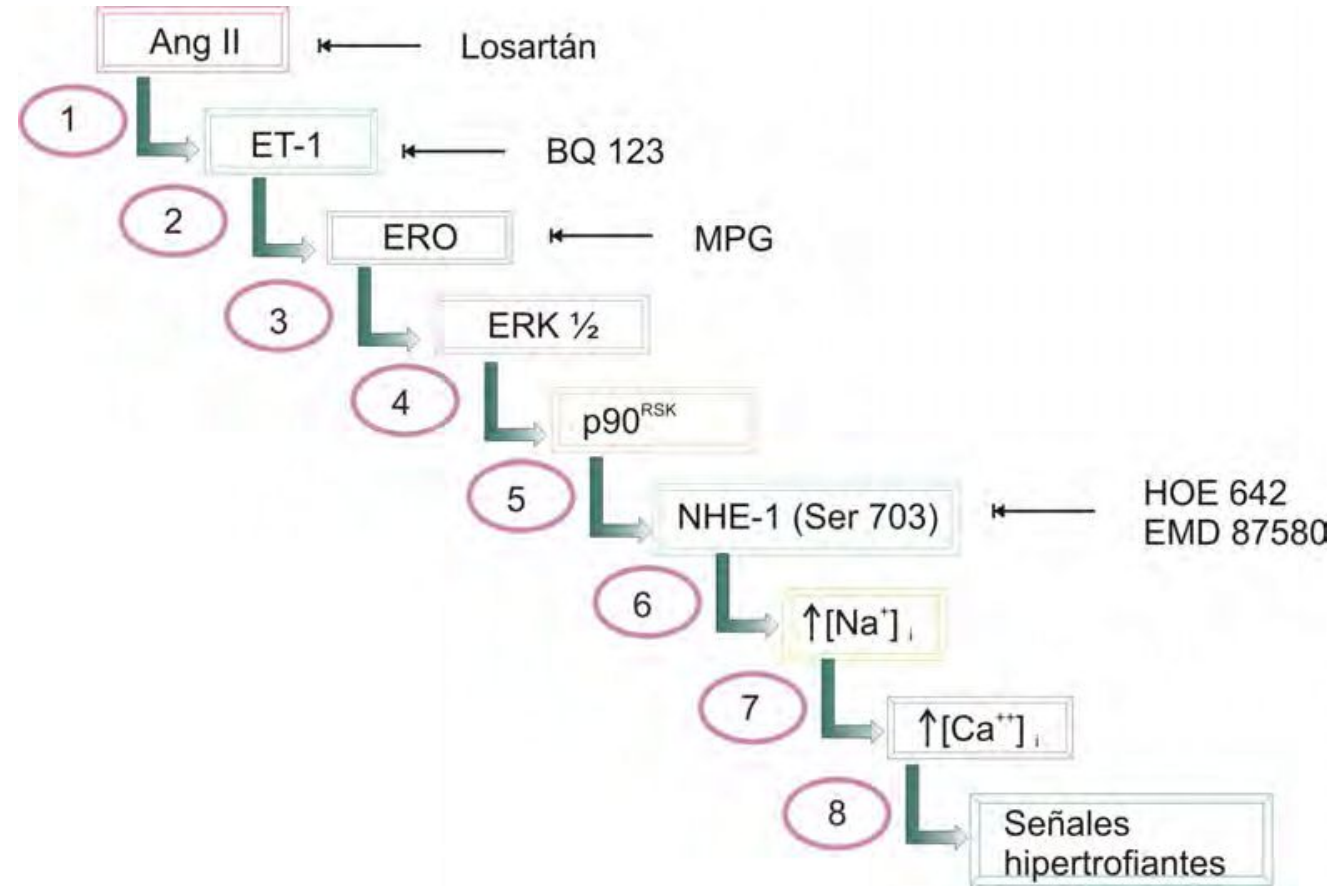

Figura 27: Cascada de regulación propuesta para la hipertrofia cardíaca mediada por Ang II/ET-1. 


\section{Bibliografía}

1. Frank JS, Langer GA. The myocardial insterstitium: its structure and its role in ionic exchange. J Cell Biol 1974; 60:586-601.

2. Reiss K, Kajstura J, Capasso JM, Marino TM, Anversa P. Impairment of myocyte contractility following coronary artery narrowing is associated with activation of the myocyte IGF 1 autocrine system, enhanced expression of late growth related genes, DNA synthesis, and myocyte nuclear mitotic division in rats. Exp Cell Res. 1993(2); 207:348-360.

3. Kajtura J, Cheng W, Reiss K, Anversa P. The IGF-1-IGF-1 receptor system modulates myocyte proliferation but not myocyte cellular hypertrophy in vitro. Exp Cell Res. 1994; 215(2):273-283.

4. Russel B, Motlagh D, Ashley WW. Form follows function: How muscle shape is regulated by work. J Appl Physiol 2000; 88:1127-1132.

5. Sadoshima J, Izumo S. The cellular and molecular response of cardiac myocytes to mechanical stress. Annu Rev Physiol 1997; 59:551- 571.

6. Merkle S, Frantz S, Schon MP, Bauersachs J, Buitrago M, Frost RJ, Schmitteckert EM, Lohse MJ, Engelhardt S. A role for caspase-1 in heart failure. Circ Res. 2007; 100:645-653.

7. McKinsey TA and Olson EN. Cardiac hypertrophy: sorting out the circuitry. Curr Opin Genet Dev. 1999; 9:267-274.

8. Chien KR. Stress pathways and heart failure. Cell. 1999; 98:555-558. 
9. MacLellan WR, Schneider MD. Success in failure: modeling cardiac decompensation in transgenic mice. Circulation. 1998; 97:1433-1435.

10. Hunter JJ, Chien KR. Signaling pathways for cardiac hypertrophy and failure. N Engl J Med. 1999; 341:1276-1283.

11. van Empel VP, De Windt LJ. Myocyte hypertrophy and apoptosis: a balancing act. Cardiovasc Res. 2004; 63(3):487-99.

12. Akhter SA, Luttrell LM, Rockman HA, laccarino G, Lefkowitz RJ, Koch WJ. Targeting the receptor-Gq interface to inhibit in vivo pressure overload myocardial hypertrophy. Science. 1998; 280(5363):574-7.

13. Esposito G, Rapacciuolo A, Naga Prasad SV, Takaoka H, Thomas SA, Koch WJ, Rockman HA. Genetic alterations that inhibit in vivo pressure-overload hypertrophy prevent cardiac dysfunction despite increased wall stress. Circulation. 2002; 105(1):85-92.

14. Wettschureck N, Rutten H, Zywietz A, Gehring D, Wilkie TM, Chen J, Chien $\mathrm{KR}$, Offermanns S. Absence of pressure overload induced myocardial hypertrophy after conditional inactivation of $\mathrm{Ga}_{q} / \mathrm{Ga}_{11}$ in cardiomyocytes. Nat Med. 2001; 7(11):1236-40.

15. Mathew J, Sleight P, Lonn E, Johnstone D, Pogue J, Yi Q, Bosch J, Sussex B, Probstfield J, Yusuf S; Heart Outcomes Prevention Evaluation (HOPE) Investigators. Reduction of cardiovascular risk by regression of electrocardiographic markers of left ventricular hypertrophy by the 
angiotensin-converting enzyme inhibitor ramipril. Circulation. 2001; 104:1615-1621.

16. Verdecchia P, Schillaci G, Borgioni C, Ciucci A, Gattobigio R, Zampi I, Reboldi G, Porcellati C. Prognostic significance of serial changes in left ventricular mass in essential hypertension. Circulation. 1998; 97:48-54.

17. Lang RM, Bierig M, Devereux RB, Flachskampf FA, Foster E, Pellikka PA, et al. Chamber Quantification Writing Group; American Society of Echocardiography's Guidelines and Standards Committee; European Association of Echocardiography. Recommendations for chamber quantification: a report from the American Society of Echocardiography's Guidelines and Standards Committee and the Chamber Quantification Writing Group, developed in conjunction with the European Association of Echocardiography, a branch of the European Society of Cardiology. J Am Soc Echocardiogr. 2005; 18(12):1440-1463.

18. Frohlich ED, Apstein C, Chobanian AV, Devereux RB, Dustan HP, Dzau V, Fauad-Tarazi F, Horan MJ, Marcus M, Massie B, Pfeffer MA, Re RN, Roccella EJ, Savage D, Shub C. The heart in hypertension. N Engl J Med. 1992; 327:998-1008.

19. Opie LH, Commerford PJ, Gersh Bj, Pfeffer MA. Controversies in ventricular remodelling. Lancet 2006; 367:356-367.

20. Frey N, Olson EN. Cardiac hypertrophy: the good, the bad and the ugly. Annu Rev Physiol. 2004; 65:45-79. 
21. Frey N, Katus HA, Olson EN, Hill JA. Hypertrophy of the heart: a new therapeutic target? Circulation. 2004; 109:1580-1589.

22. Selvetella G, Hirschb E, Nottea A, Taroneb G, Lemboa G. Adaptive and maladaptive hypertrophic pathways: points of convergence and divergence. Cardiovasc Res. 2004; 63:373-380.

23. McMullen JR, Jennings GL. Differences between pathological and physiological cardiac hypertrophy: novel therapeutic strategies to treat heart failure. Clin Exp Pharmacol Physiol. 2007 ;34(4):255-62.

24. Johnatty SE, Dyck JR, Michael LH, Olson EN, Abdellatif M. Identification of gene regulated during machanical load-induced cardiac hypertrophy. J Mol Cell Cardiol. 2000; 32:805-815.

25. Lorell $\mathrm{BH}$, Carabello BA. Left ventricular hypertrophy: pathogenesis, detection, and prognosis. Circulation. 2000; 102 470-479.

26. Klem M, Feelisch M, Krebber T, Deussen A, Motz W, Strauer BE. Role of nitric oxide in the regulation of coronary vascular tonein heart from hyperesive rats. Maintenance of nitric oxide-forming capacity and increased basal production of nitric oxide. Hypertesion. 1995; 25:186-193.

27. Feldman AM, Weinberg EO, Ray PE, Lorell BH. Selective change in cardiac gene expression during compensated hypertrophy and the transition to cardiac decompensation in rats with chronic aortic banding. Circ Res. 1993; 73:284-192. 
28. Parker TG. Molecular biology of cardiac growth and hypertrophy. Herz. 1993; 18(4):245-255.

29. Schaub MC, Hefti MA, Harder BA, Eppenberger HM. Various hypertrophic stimuli induce distinct phenotypes in cadiomyocytes. J Mol Med. 1997; 75(11-12):901-920.

30. Sadoshima J, Xu Y, Slayter HS, Izumo S. Autocrine release of angiotensin II mediates stretch-induced hypertrophy of cardiac myocytes in vitro. Cell. 1993; 75:977-984.

31. Yamazaki T, Komuro I, Kudoh S, Zou Y, Shiojima I, Hiroi Y, Mizuno T, Maemura K, Kurihara H, Aikawa R, Takano H, Yazaki Y. Endothelin is involved in machanical stress-induced cardiomyocyte hypertrophy. J Biol Chem. 1996; 271:3221-3228.

32. Kojima M, Shiojima I, Yamazaki T, Komuro I, Zou Y, Ying W, Mizuno T, Ueki K, Tobe K, Kadowaki T, Nagai R, Yazaki Y. Angiotensin II receptor antagonist TCV-116 induces regression of hypertensive left ventricular hypertrophy in vivo and inhibit the intracellular signalling pathway of stretchmediated cardiomyocyte hypertrophy in vivo. Circulation. 1994; 89:22042211.

33. Ito $\mathrm{H}$, Hiroe $\mathrm{M}$, Hirata $\mathrm{Y}$, Fujisaki $\mathrm{H}$, Adachi $\mathrm{S}$, Akimoto $\mathrm{H}$, Ohta $\mathrm{Y}$, Marumo F. Endothelin $\mathrm{ET}_{\mathrm{A}}$ receptor antagonist blocks cardiac hypertrophy provoked by hemodinamic overload. Circulation. 1994; 89:2198-2203. 
34. Kramer BK, Smith TW, Kelly RA. Endothelin and increased contractility in adult rat ventricular myocytes. Role of intracellular alkalosis induced by activation of the protein kinase C-dependent $\mathrm{Na}^{+} / \mathrm{H}^{+}$exchanger. Circ Res. $1991 ; 68: 269-279$.

35. Matsui H, Barry WH, Livsey C, Spitzer KW. Angiotensin II stimulates sodium-hydrogen exchange in adult rabbit ventricular myocytes. Cardiovasc Res. 1995; 29:215-221.

36. Karmazyn M, Gan XT, Humphreys RA, Yoshida H, Kusumoto K The myocardial $\mathrm{Na}(+)-\mathrm{H}(+)$ exchange: structure, regulation, and its role in heart disease. Circ res 1999; 85(9): 777-786.

37. Baartscheer A, Schumacher CA, van Borren MM, Belterman CN, Coronel $\mathrm{R}$, Fiolet JW. Increased $\mathrm{Na}+/ \mathrm{H}+-$-exchange activity is the cause of increased $[\mathrm{Na}+] \mathrm{i}$ and underlies disturbed calcium handling in the rabbit pressure and volume overload heart failure model. Cardiovasc Res. 2003; 57(4):1015-24.

38. Kilic A, Velic A, De Windt LJ, Fabritz L, Voss M, Mitko D, Zwiener M, Baba HA, van Eickels M, Schlatter E, Kuhn M. Enhanced activity of the myocardial $\mathrm{Na}+/ \mathrm{H}+$ exchanger $\mathrm{NHE}-1$ contributes to cardiac remodeling in atrial natriuretic peptide receptor-deficient mice. Circulation. 2005; 112(15):230717.

39. Fliegel L, Karmazyn M. The cardiac $\mathrm{Na}^{+} / \mathrm{H}^{+}$exchanger: a key downstream mediator for the cellular hypertrophic effects of paracrine, autocrine and hormonal factors. Biochem Cell Biol. 2004; 82:626-635. 
40. Cingolani HE, Ennis IL. Sodium-hydrogen exchanger, cardiac overload, and myocardial hypertrophy. Circulation. 2007; 115(9):1090-100.

41. De la Sierra A, Coca A, Pare JC, Sanchez M, Valls V, Urbano-Marquez A. Erytrocyte ion floxes in essential hypertensive patients with left ventricular hypertrophy. Circulation. 1993; 88:1628-1633.

42. Pérez NG, Álvarez BV, Camilión de Hurtado MC, Cingolani HE. $\mathrm{pH}_{\mathrm{i}}$ regulation in myocardium of spontaneously hypertensive rat. Compensated enhanced activity of the $\mathrm{Na}^{+} / \mathrm{H}^{+}$exchanger. Circ Res. 1995; 77:1192-1200.

43. Schussheim AE, Radda GK. Altered $\mathrm{Na}^{+} / \mathrm{H}^{+}$exchange activity in the spontaneously hypertensive perfused rat heart. J Mol Cell Cardiol. 1995; 27:1475-1481.

44. Cingolani HE, Rebolledo OR, Portiansky EL, Pérez NG, Camilión de Hurtado MC. Regression of hypertensive myocardial fibrosis by $\mathrm{Na}^{+} / \mathrm{H}^{+}$ exchange inhibition. Hypertension. 2003; 41(2):373-377.

45. Camilión de Hurtado MC, Portiansky EL, Pérez NG, Rebolledo OR, Cingolani HE. Regression of cardiomyocyte hypertrophy in SHR following chronic inhibition of the $\mathrm{Na}^{+} / \mathrm{H}^{+}$exchanger. Cardiovasc Res. 2002; 53(4):862-868.

46. Zhu W, Zou Y, Shiojima I, Kudoh S, Aikawa R, Hayashi D, Mizukami M, Toko H, Shibasaki F, Yazaki Y, Nagai R, Komuro I. $\mathrm{Ca}^{2+}$ /calmodulindependent kinase II and calcineurin play critical roles in endothelin-1induced cardiomyocyte hypertrophy. J Biol Chem. 2000; 275:15239-45. 
47. Baker KM, Booz GW, Dostal DE. Cardiac Actions of Angiotensin II: Role of an Intracardiac Renin-Angiotensin System. Annu Rev Physiol. 1992; $54: 227-241$

48. Braun-Menéndez E, Fasciolo JC, Leloir LF, Muñoz JM. The Substance Causing Renal Hypertension. J Physiol. 1940; 98:283-298.

49. Johnston $\mathrm{Cl}$. Renin angiotensin system: A dual tissue and hormonal system for cardiovascular control. J Hypertension. 1992; 10:S13-S26.

50. Kunapuli SP, Kumar A. Molecular Cloning of Human Angiotensinogen cDNA and evidence for the presence of its mRNA in rat heart. Circ Res. 1987; 60:786-790.

51. Schwarz H, Bumpus FM, Page IH. Synthesis of a biologically active octapeptide similar to natural isoleucine angiotonin octapeptide. J.Am.Chem.Soc. 1957. 5697-5703.

52. Tsai BS, Peach MJ, Khosla MC, Bumpus FM. Synthesis and evaluation of (Des-Asp1) angiotensin I as a precursor for (Des-Asp1) angiotensin II (Angiotensin III). J Med Chem. 1975; 18(12):1180.1183.

53. Dostal DE, Rothblum KC, Conrad KM, Cooper GR, Baker KM. Detection of angiotensin I and II in cultured rat cardiac myocyte and fibroblasts: Evidence for local production. Am J Physiol (Cell Physiol). 1992; 263:C851-C863.

54. Dell'Italia LJ, Meng QC, Balcells E, Wei CC, Palmer R, Hageman GR, Durand J, Hankes GH, Oparil S. Compartmentalization of Angiotensin II 
generation in the dog heart: evidence for independient mechanisms in intravascular and interstitial spaces. J Clin Invest. 1997; 100; 253-258.

55. Miyata S, Haneda T, Osaka J, Kikuchi K. Renin-angiotensin system in stretch-induced hypertrophy of cultured neonatal rat heart cells. Eur $\mathrm{J}$ Pharmacol. 1996; 307:81-88.

56. Yamazaki T, Komuro I, Kudoh S, Zou Y, Shiojima I, Mizuno T, Takano H, Hiroi Y, Veki K, Tobe K, Kadowaki T, Nagai R, Yazaki Y. Angiotensin II partly mediates machanical stress-induced cardiac hypertrophy. Circ Res. $1995 ; 77: 258-265$.

57. Alvarez BV, Pérez NG, Ennis IL, Camilión de Hurtado MC, Cingolani HE. Mechanisms underlying the increase in force and $\mathrm{Ca}^{+2}$ transient that follow strech of cardiac muscle: a possible explanation of the Anrep effect. Circ Res. 1999; 85:716-722.

58. Pérez NG, de Hurtado MC, Cingolani HE. Reverse mode of the $\mathrm{Na}^{+}-\mathrm{Ca}^{2+}$ exchange after myocardial stretch: underlying mechanism of the slow force response. Circ Res. 2001; 88(4):376-82.

59. Peach MJ. Renin-angiotensin system: biochemistry and mechanisms of action. Physiol Rev. 1977; 57(2):313-370.

60. Dudley DT, Panek RL, Major TC, Lu GH, Bruns RF, Klinkefus BA, Hodges JC, Weishaar RE. Subclasses of angiotensin II binding sites and their functional significance. Mol Pharmacol. 1990; 38(3):370-377. 
61. Whitebread S, Mele M, Kamber B, de Gasparo M. Preliminary biochemical characterization of two angiotensin II receptor subtypes. Biochem Biophys Res Commun. 1989; 163(1):284-291.

62. Chang RS, Loti VJ. Angiotensin receptor subtypes in rat, rabbit and monkey tissues: relative distribution and species dependency. Life Sci. 1991; 49: 1485-1490.

63. Nozawa Y, Haruno A, Oda N, Yamasaki Y, Matsuura N, Yamada S, Inabe K, Kimura R, Suzuki H, Hocino T. Angiotensin II receptor subtypes in bovine and human ventricular myocardium. J. Pharmacol. Exp. Ther. 1994; 270:566-571.

64. Ishihata A, Endoh M. Species-related differences in inotropic effects of angiotensin II in mammalian ventricular muscle: receptors, subtypes and phosphoinositide hydrolysis. Br J Pharmacol. 1995; 114(2):447-453.

65. Scott AL, Chang RS, Lotti VJ, Siegl PK. Cardiac angiotensin receptors: effects of selective angiotensin II receptor antagonists, DUP 753 and PD 121981, in rabbit heart. J Pharmacol Exp Ther. 1992; 261(3):931-935.

66. Sechi LA, Griffin CA, Grady EF, Kalinyak JE, Schambelan M. Characterization of angiotensin II receptor subtypes in rat heart. Circ Res. 1992; 71(6):1482-1489.

67. Lopez JJ, Lorell BH, Ingelfinger JR, Weinberg EO, Schunkert H, Diamant D, Tang SS. Distribution and function of cardiac angiotensin AT1 and AT2 
receptor subtypes in hypertrophied rat hearts. Am. J. Physiol. 1994; 267:H844-852.

68. Masaki H, Kurihara T, Yamaki A, Inomata N, Nozawa Y, Mori Y, Murasawa S, Kizima K, Maruyama K, Horiuchi M, Dzau VJ, Takahashi H, Iwasaka T, Inada M, Matsubara H. Cardiac-specific overexpression of angiotensin II AT2 receptor causes attenuated response to $A T_{1}$ receptor-mediated pressor and chonotropic effects. J. Clin. Invest. 1998; 101:527-535.

69. Booz GW, Baker KM. Role of type 1 and 2 angiotensin receptors in angiotensin induced cardiomyocyte hypertrophy. Hypertension. 1996; 28:635-640.

70. Bartunek J, Weinberg EO, Tajima M, Rohrbach S, Lorell BH. Angiotensin II type 2 receptor blockade amplifies the early signals of cardiac growth response to angiotensin II in hypertrophied hearts. Circulation. 1999; 99:2225.

71. Dzau VJ, Sasamura H, Hein L. Heterogeneity of angiotensin synthetic pathways and receptor subtypes: physiological and pharmacological implications. Hypertension Suppl. 1993; 11(3):S13-18.

72. Stoll M, Steckelings UM, Paul M, Bottari SP, Metzger R, Unger T. The angiotensin $\mathrm{AT}_{2}$-receptor mediates inhibition of cell proliferation in coronary endothelial cells. J Clin Invest. 1995; 95(2):651-657.

73. Matsubara H. Pathophysiological role of angiotensin II type 2 receptor in cardiovascular and renal diseases. Circ Res. 1998; 83(12):1182-1191. 
74. Horiuchi M, Akishita M, Dzau VJ. Recent progress in angiotensin II type 2 receptor research in the cardiovascular system. Hypertension. 1999; 33(2):613-621.

75. Catt K, Abbott A. Molecular cloning of angiotensin II receptors may presage further receptor subtypes. Trends Pharmacol Sci. 1991; 12(8):279-281.

76. Timmermans PB, Wong PC, Chiu AT, Herblin WF, Benfield P, Carini DJ, Lee RJ, Wexler RR, Saye JA, Smith RD. Angiotensin II receptors and angiotensin II receptor antagonists. Pharmacol Rev. 1993; 45(2):205-251.

77. Schmermund A, Lerman LO, Ritman EL, Rumberger JA. Cardiac production of angiotensin II and its pharmacologic inhibition: effects on the coronary circulation. Mayo Clin Proc. 1999; 74(5):503-513.

78. Silvestre JS, Heymes C, Oubenaissa A, Robert V, Aupetit-Faisant B, Carayon A, Swynghedauw B, Delcayre C. Activation of cardiac aldosterone production in rat myocardial infarction: effect of angiotensin II receptor blockade and role in cardiac fibrosis. Circulation. 1999; 99(20):2694-2701.

79. de Gasparo M, Catt KJ, Inagami T, Wright HW, Unger T. Internacional Union of Pharmacology: XXIII: the angiotensin II receptors. Pharmacol. Rev. 52: 415-472, 2000.

80. Rockman HA, Koch WJ, Leftkowitz RJ. Seven transmembrane-spanning receptors and heart function. Nature. 2002; 415:206-212. 
81. Fabiato A. Inositol trisphosphate induced release of $\mathrm{Ca}^{+2}$ from the sarcoplasmic reticulum of skinned cardiac cells. Biophys. J. 1986; 49:190199.

82. Berridge MJ. Inositol trisphosphate and calcium signalling. Nature. 1993; $361(6410): 315-325$

83. Wu X, Zhang T, Bossuyt J, Li X, McKinsey TA, Dedman JR, Olson EN, Chen J, Brown JH, Bers DM. Local InsP3-dependent perinuclear $\mathrm{Ca}^{2+}$ signaling in cardiac myocyte excitation-transcription coupling. Clin Invest. 2006; 116(3):675-682.

84. Wetsel WC, Khan WA, Merchenthaler I, Rivera H, Halpern AE, Phung HM, Negro-Vilar A, Hannun YA. Tissue and cellular distribution of the extended family of protein kinase C isoenzymes. J Cell Biol. 1992; 117(1):121-33.

85. Dorn GW, Force T. Protein kinase cascades in the regulation of cardiac hypertrophy. J Clin Invest. 2005; 115(3): 527-537.

86. Moor A, Karmazyn M, Gan XT, Fliegel L. Protein kinase mediated regulation of the $\mathrm{Na}+/ \mathrm{H}+$ exchanger isoform $1(\mathrm{NHE}-1)$ in ischemic and ischemicreperfused rat heart. J Biol Chem. 2001, 27:16113-16122.

87. Frey N, McKinsey TA, Olson TN. Decoding calcium signals involved in cardiac growth and function. Nat Med. 2000; 6:1221-1227.

88. Mattiazzi A. Positive inotropic effect of angiotensin II. Increases in intracellular $\mathrm{Ca}^{2+}$ or changes in myofilament $\mathrm{Ca}^{2+}$ responsiveness? Pharmacol Toxicol Methods. 1997; 37(4):205-214. 
89. Dostal DE, Hunt RA, Kule CE, Bhat GJ, Karoor V, McWhinney CD, Baker KM. Molecular mechanisms of angiotensin II in modulating cardiac function: intracardiac effects and signal transduction pathways. J Mol Cell Cardiol. 1997; 29(11):2893-2902.

90. Garrington TP and Johnson GL. Organization and regulation of mitogenactivated protein kinase signaling pathways. Curr Opin Cell Biol. 1999; $11: 211-218$.

91. Lokuta AJ, Cooper C, Gaa ST, Wang HE, Rogers TB. Angiotensin II stimulates the release of phospholipid-derived second messengers through multiple receptor subtypes in heart cells. J Biol Chem. 1994; 269(7):48324838.

92. Nakajima M, Hutchinson HG, Fujinaga M, Hayashida W, Morishita R, Zang L, Horiuchi M, Pratt RE, Dzau VJ. The angiotensin II type $2\left(\mathrm{AT}_{2}\right)$ receptor antagonizes the growth effects of the AT1 receptors: gain-of-function study using gene transfer. Procd Natl Acad Sci USA 1995; 92:10663-10667.

93. Yanagisawa M, Kurihara $\mathrm{H}$, Kimura S, Tomobe $\mathrm{Y}$, Kobayashi M, Mitsui $\mathrm{Y}$, Yazaki Y, Goto K, Masaki T. A novel potent vasoconstrictor peptide produced by vascular endothelial cells. Nature. 1988; 332(6163):411-415.

94. Inoue A, Yanagisawa M, Kimura S, Kasuya Y, Miyauchi T, Goto K, Masaki T The human endothelin family: three structurally and pharmacologically distinct isopeptides predicted by three separate genes. Proc Natl Acad Sci U S A. $1989 ; 86(8): 2863-2867$. 
95. Laporte S, Denault JB, D'Orleans-Juste P, Leduc R. Presence of furin mRNA in cultured bovine endothelial cells and possible involvement of furin in the processing of the endothelin precursor. J Cardiovasc Pharmacol. 1993; 22 (Suppl 8):S7-10.

96. Blais V, Fugere M, Denault JB, Klarskov K, Day R, Leduc R. Processing of proendothelin-1 by members of the subtilisin-like pro-protein convertase family. FEBS Lett. 2002; 524(1-3):43-48.

97. Valdenaire O, Lepailleur-Enouf D, Egidy G, Thouard A, Barret A, Vranckx R, Tougard C, Michel JB. A fourth isoform of endothelin-converting enzyme $(E C E-1)$ is generated from an additional promoter molecular cloning and characterization. Eur J Biochem. 1999; 264(2):341-349.

98. Valdenaire O, Barret A, Schweizer A, Rohrbacher E, Mongiat F, Pinet F, Corvol P, Tougard C. Two di-leucine-based motifs account for the different subcellular localizations of the human endothelin-converting enzyme (ECE1) isoforms. J Cell Sci. 1999; 112 Pt 18:3115-3125.

99. Emoto N, Yanagisawa M. Endothelin-converting enzyme-2 is a membranebound, phosphoramidon-sensitive metalloprotease with acidic $\mathrm{pH}$ optimum. J Biol Chem. 1995; 270(25):15262-15268.

100. Hasegawa H, Hiki K, Sawamura T, Aoyama T, Okamoto Y, Miwa S, Shimohama S, Kimura J, Masaki T. Purification of a novel endothelinconverting enzyme specific for big endothelin-3. FEBS Lett. 1998; 428(3):304-308. 
101. Yanagisawa M, Inoue A, Takuwa Y, Mitsui Y, Kobayashi M, Masaki T. The human preproendothelin-1 gene: possible regulation by endothelial phosphoinositide turnover signaling. Cardiovasc Pharmacol. 1989; 13 Suppl 5:S13-17; discussion S18.

102. Gray GA. Generation of endothelin. En Molecular biology and pharmacology of the endothelins. Gray GA, Webb DJ, eds RG Landers: Austin. 1995 pág 13-32.

103. Shinmi O, Kimura S, Sawamura T, Sugita Y, Yoshizawa T, Uchiyama Y, Yanagisawa M, Goto K, Masaki T, Kanazawa I. Endothelin-3 is a novel neuropeptide: isolation and sequence determination of endothelin-1 and endothelin-3 in porcine brain. Biochem Biophys Res Commun 1989; 164(1):587-593.

104. Endoh M, Fujita S, Yang HT, Talukder MA, Maruya J, Norota I. Endothelin: receptor subtypes, signal transduction, regulation of $\mathrm{Ca}^{2+}$ transients and contractility in rabbit ventricular myocardium. Life Sci. 1998; 62:1485-1489.

105. Talukder MA, Norota I, Sakurai K, Endoh M. Inotropic response of rabbit ventricular myocytes to endothelin-1: difference from isolated papillary muscles. Am J Physiol Heart Circ Physiol 2001; 281(2):H596-605.

106. Simonson MS, Rooney A. Characterization of endothelin receptors in mesangial cells: evidence for two functionally distinct endothelin binding sites. Mol Pharmacol. 1994;46(1):41-50. 
107. Takanashi M, Endoh M. Characterization of positive inotropic effect of endothelin on mammalian ventricular myocardium. Am J Physiol. 1991; 261(3 Pt 2):H611-619.

108. Gu XH, Ou RC, Casley DJ, Daly MJ, Nayler WG. Effect of age on endothelin-1 binding sites in rat cardiac ventricular membranes. J Cardiovasc Pharmacol. 1992; 19(5):764-769.

109. Kasai H, Takanashi M, Takasaki C, Endoh M. Pharmacological properties of endothelin receptor subtypes madiating positive inotropic effects in rabbit heart. Am J Physiol. 1994; 266:h2220-2228.

110. Hosoda K, Nakao K, Arai H, Suga S, Ogawa Y, Mukoyama M, Shirakami G, Saito Y, Nakanishi S, Imura H. Cloning and expression of human endotheli1 receptor c-DNA. FEBS Lett. 1991; 287:23-26.

111. Ogawa Y, Nakao K, Arai H, Nakagawa O, Hosoda K, Suga S, Nakanishi S, Imura $\mathrm{H}$. Molecular cloning of a non-isopeptide-selective human endothelin receptor. Biochem Biophys Res Commun. 1991; 178:248-255.

112. Wanner TD, Mitchell JA, De Nucci G, Vane JR. Endothelin-1 and endothelin3 release EDRF from isolated perfused arterial vessels of the rat ad rabbit. J Cardiovasc Pharmacol. 1989; 13:S85-88.

113. De Nucci G, Thomas R, D'Orleans-Juste P, Antunes Ewalder C, Wanner TD, Vane JR. Pressor effect of circulating endothelin are limited by its removal in the pulmonary circulation and by the release of prostacyclin and 
endothelium-derived relaxing factor. Proc Natl Acad Sci USA. 1998; 85:9797-9800.

114. Haynes WG, Strachan FE, Webb DJ. Endothelin $E T_{A}$ and $E T_{B}$ receptors mediate vasoconstriction of human resistance and capacitance vessels in vivo. Circulation. 1995; 92:357-363.

115. Davenport AP, Maguirre JJ. Is endothelin-induced vasoconstriction mediated only by ETA receptors in humans? Trends Pharmacol Sci. 1994; 15:9-11.

116. Flynn MA, Haleen SJ, Welch KM, Cheng XM, Reynolds EE. Endothelin B receptors on human endothelial and smooth-muscle cells show equivalent binding pharmacology. J Cardiovas Pharmacol. 1998; 32:106-116.

117. Kitamura K, Shiraishi N, Singer WD, Handlogten ME, Tomita K, Miller Tyler. Endothelin-B receptors activate $\mathrm{Ga}_{13}$. Am J Physiol 1999; 276(4):C930-937.

118. Ishikawa T, Li LM, Shinmi O, Kimura S, Yanagisawa M, Goto K, Masaki T. Characteristics of binding of endothelin-1 and endothelin-3 to rat hearts. Developmental changes in mechanical responses and receptor subtypes. Circ Res. 1991; 69(4):918-926.

119. Karne S, Jayawikreme CK, Lerner MR. Cloning and characterization of an ET-3 specific receptor (ETC receptor) from Xenopus laevis dermal melanophores. J Biol Chem. 1993; 268:19126-19133.

120. Giordano FJ. Oxygen, oxidative stress, hypoxia, and heart failure. J Clin Invest. 2005; 115:500 -508 . 
121. Nordberg J, Arner ES. Reactive oxygen species, antioxidants, and the mammalian thioredoxin system. Free Radic Biol Med. 2001; 31:1287-1312.

122. Murdoch CE, Zhang M, Cave AC, Shah AM. NADPH oxidase-dependent redox signalling in cardiac hypertrophy, remodelling and failure. Cardiovasc Res. 2006; 71:208 -215.

123. Sawyer DB, Siwik DA, Xiao L, Pimentel DR, Singh K, Colucci WS. Role of oxidative stress in myocardial hypertrophy and failure. J Mol Cell Cardiol. $2002 ; 34: 379-388$.

124. Feil R, Lohmann SM, de Jonge H, Walter U, Hofmann F. Cyclic GMPdependent protein kinases and the cardiovascular system: insights from genetically modified mice. Circ Res. 2003; 93:907-916.

125. Hare JM. Nitroso-redox balance in the cardiovascular system. N Engl J Med. $2004 ; 351: 2112-2114$.

126. Paolocci N, Ekelund UE, Isoda T, Ozaki M, Vandegaer K, Georgakopoulos D, Harrison RW, Kass DA, Hare JM. cGMP-independent inotropic effects of nitric oxide and peroxynitrite donors: potential role for nitrosylation. Am J Physiol Heart Circ Physiol. 2000; 279:H1982-H1988.

127. Katori T, Donzelli S, Tocchetti CG, Miranda KM, Belardi DF, Cormaci G, Thomas DD, Ketner EA, Lee MJ, Mancardi D, Wink DA, Kass DA, Paolocci N. Peroxnitrite and myocardial contractility: in vivo versus in vitro effects. Free Radic Biol Med. 2006; 41:1606 -1618. 
128. Turko IV, Murad F. Protein nitration in cardiovascular diseases. Pharmacol Rev. 2002; 54:619 -634.

129. Pacher P, Schulz R, Liaudet L, Szabo C. Nitrosative stress and pharmacological modulation of heart failure. Trends Pharmacol Sci. 2005; 26:302-310.

130. Hassoun PM, Yu FS, Zulueta JJ, White AC, Lanzillo JJ. Effect of nitric oxide and cell redox status on the regulation of endothelial cell xanthine dehydrogenase. Am J Physiol. 1995; 268:L809 -L817.

131. Cote CG, Yu FS, Zulueta JJ, Vosatka RJ, Hassoun PM. Regulation of intracellular xanthine oxidase by endothelial-derived nitric oxide. Am J Physiol. 1996; 271:L869 -L874.

132. Shinyashiki M, Pan CJ, Lopez BE, Fukuto JM. Inhibition of the yeast metal reductase heme protein fre1 by nitric oxide (NO): a model for inhibition of NADPH oxidase by NO. Free Radic Biol Med. 2004; 37:713-723.

133. Clancy RM, Leszczynska-Piziak J, Abramson SB. Nitric oxide, an endothelial cell relaxation factor, inhibits neutrophil superoxide anion production via a direct action on the NADPH oxidase. J Clin Invest. 1992; $90: 1116-1121$.

134. Ortiz MC, Manriquez MC, Romero JC, Juncos LA. Antioxidants block angiotensin II-induced increases in blood pressure and endothelin. Hypertension. 2001;38:655-659. 
135. Ortiz MC, Sanabria E, Manriquez MC, Romero JC, Juncos LA. Role of endothelin and isoprostanes in slow pressor responses to angiotensin II. Hypertension. 2001; 37:505-510.

136. Zima AV, Blatter LA. Redox regulation of cardiac calcium channels and transporters. Cardiovasc Res. 2006; 71:310 -321.

137. Kawakami M, Okabe E. Superoxide anion radical-triggered Ca2 $\square$ release from cardiac sarcoplasmic reticulum through ryanodine receptor Ca2 $\square$ channel. Mol Pharmacol. 1998;53:497-503.

138. Fearon IM, Palmer AC, Balmforth AJ, Ball SG, Varadi G, Peers C.Modulation of recombinant human cardiac L-type $\mathrm{Ca}^{+2}$ - channel $\mathrm{\alpha}_{1 \mathrm{C}}$ subunits by redox agents and hypoxia. J Physiol. 1999; 514:629-637.

139. Xu KY, Zweier JL, Becker LC. Hydroxyl radical inhibits sarcoplasmic reticulum $\mathrm{Ca}^{+2}$-ATPase function by direct attack on the ATP binding site. Circ Res. 1997; 80:76 -81.

140. Adachi T, Weisbrod RM, Pimentel DR, Ying J, Sharov VS, Schoneich C, Cohen RA. S-Glutathiolation by peroxynitrite activates SERCA during arterial relaxation by nitric oxide. Nat Med. 2004; 10:1200 -1207.

141. Orlowski J, Grinstein S. En M. Karmazyn, M. Avkiran, L. Fliegel (Eds.), The $\mathrm{Na}+/ \mathrm{H}+$ exchanger, from molecular to its role in disease. 2003,pág. 17-34. Boston, Dordrecht, London:Kluwer Academic Publishers.

142. Wakabayashi S, Pang T, Su X, Shigekawa, M. A novel topology model of the human $\mathrm{Na}+/ \mathrm{H}+$ exchanger isoform $1 \mathrm{~J}$ Biol Chem 2000; 275:7942-7949. 
143. Counillon L, Franchi A, Pouyssegur J. A point mutation of the $\mathrm{Na}+/ \mathrm{H}+$ exchanger gene (NHE-1) and amplification of the mutated allele confers amiloride resistance upon chronic acidosis. Proc Natl Acad Sci U S A. 1990; $90: 4508-4512$.

144. Murtazina B, Booth BJ, Bullis BL, Singh DN, Fliegel L. Functional analysis of polar amino acid residues in membrane associated regions of the NHE-1 isoform of the $\mathrm{Na}+/ \mathrm{H}+$ exchanger. Eur J Biochem 2001; 268:1-13.

145. Sabri A, Byron KL, Samarel AM, Bell J, Lucchesi PA. Hydrogen peroxide activates mitogen-activated protein kinases and $\mathrm{Na}+/ \mathrm{H}+$ exchange in neonatal rat cardiac myocytes. Circ Res. 1998; 82:1053-1062.

146. Malo ME, Fliegel L. Physiological role and regulation of the $\mathrm{Na}+/ \mathrm{H}+$ exchanger. Can J Physiol Pharmacol. 2006; 84(11):1081-95.

147. Li X, Liu Y, Kay CM, Muller-Esterl W, Fliegel L. The Na+/H+ exchanger cytoplasmic tail: Structure, function, and interactions with tescalcin. Biochem. 2003; 42:7448-7456.

148. Li X, Alvarez B, Casey JR, Reithmeier R A, Fliegel L. Carbonic anhydrase II binds to and enhances activity of the $\mathrm{Na}+/ \mathrm{H}+$ exchanger. J Biol Chem 2002; 277:36085-36091.

149. Putney LK, Denker SP, Barber DL. The changing face of the $\mathrm{Na}+/ \mathrm{H}+$ exchanger, NHE-1: Structure, regulation, and cellular actions. Annu Rev Pharmacol Toxicol. 2002; 42:527-552. 
150. Wang $H$, Singh $D$, Fliegel $L$. The $N a+/ H+$ antiporter potentiates growth and retinoic-acid induced differentiation of P19 embryonal carcinoma cells. J Biol Chem 1997; 272:26545-26549.

151. Denker SP, Barber DL. Cell migration requires both ion translocation and cytoskeletal anchoring by the $\mathrm{Na}+/ \mathrm{H}+$ exchanger NHE-1. J Cell Biol 2002; 159:1087-1096.

152. Boerth SR, Zimmer DB, Artman M. Steady-state mRNA levels of the sarcolemmal $\mathrm{Na}+/ \mathrm{Ca}^{+2}$ exchanger peak near birth in developing rabbit and rat hearts. Circ Res. 1994; 74(2):354-359.

153. Studer R, Reinecke H, Vetter R, Holtz J, Drexler H. Expression and function of the cardiac $\mathrm{Na}+/ \mathrm{Ca}^{+2}$ exchanger in postnatal development of the rat, in experimental-induced cardiac hypertrophy and in the failing human heart. Basic Res Cardiol. 1997; 92 Suppl 1:53-58.

154. Vetter R, Studer R, Reinecke H, Kolar F, Ostadalova I, Drexler H. Reciprocal changes in the postnatal expression of the sarcolemmal $\mathrm{Na}+/ \mathrm{Ca}^{+2}$ exchanger and SERCA2 in rat heart. J Mol Cell Cardiol. 1995; 27(8):16891701.

155. Koban MU, Moorman AF, Holtz J, Yacoub MH, Boheler KR. Expressional analysis of the cardiac $\mathrm{Na}+/ \mathrm{Ca}^{+2}$ exchanger in rat development and senescence. Cardiovasc Res. 1998; 37(2):405-423. 
156. Volz A, Piper HM, Siegmund B, Schwartz P. Longevity of adult ventricular rat heart muscle cells in serum-free primary culture. J Mol Cell Cardiol. 1991 23(2):161-73.

157. Labarca C, Paigen K. A simple, rapid and sensitive DNA assay procedure. Anal Biochem 1979; 102:344-352.

158. Cingolani HE, Villa-Abrille MC, Cornelli M, Nolly A, Ennis IL, Garciarena C, Suburo AM, Torbidoni V, Correa MV, Camilión de Hurtado MC, Aiello EA. The positive inotropic effect of angiotensin II: role of endothelin-1 and reactive oxygen species. Hypertension 2006; 47(4):727-34).

159. Imai T, Hirata Y, Emori T, Yanagisawa M, Masaki T, Marumo F. Induction of endothelin-1 gene by angiotensin and vasopressin in endothelial cells. Hypertension 1992; 19:753-757.

160. Ito H, Hirata Y, Adachi S, Tanaka M, Tsujino M, Koike A, Nogami A, Murumo F, Hiroe M. Endothelin-1 is an autocrine/paracrine factor in the mechanism of angiotensin II-Induced hypertrophy in cultured rat cardiomyocites. J Clin Invest 1993; 92:398-403.

161. Chua BH, Chua CC, Diglio CA, Siu BB. Regulation of endothelin-1 mRNA by angiotensin II in rat heart endothelial cells. Biochim Biophys Acta 1993; 1178:201-206.

162. Rajagopalan S, Laursen JB, Borthayre A, Kurz S, Keiser J, Haleen S, Giaid A, Harrison DG. Role of endothelin-1 in angiotensin II-mediated hypertension. Hypertension 1997; 30:29-34. 
163. Camilion de Hurtado MC, Álvarez BV, Pérez NG, Ennis IL, Cingolani HE. Angiotensin II activates $\mathrm{Na}^{+}-$independent $\mathrm{Cl} / / \mathrm{HCO}_{3}{ }^{-}$exchange in ventricular myocardium. Circ Res. 1998; 82:473-481.

164. Pimentel DR, Amin JK, Xiao L, Miller T, Viereck J, Oliver-Krasinski J, et al. Reactive oxygen species mediate amplitude-dependent hypertrophic and apoptotic responses to mechanical stretch in cardiac myocytes. Circ Res $2001 ; 89: 453-60$.

165. Matsushita H, Lee KK, Tsao PS. Cyclic strain induces reactive oxygen species production via an endothelial NADPH oxidase. J Cell Biochem 2001; 81:99- 106.

166. Griendling KK, Minieri CA, Ollerenshaw JD, Alexander RW. Angiotensin II stimulates NADH and NADPH oxidase activity in cultured vascular smooth muscle cells. Circ Res 1994; 74:1141- 8.

167. Touyz RM, Chen X, Tabet F, Yao G, He G, Quinn MT, et al. Expression of a functionally active gp91phox-containing neutrophil-type NADPH oxidase in smooth muscle cells from human resistance arteries: regulation by angiotensin II. Circ Res 2002; 90:1205- 13.

168. Li JM, Shah AM. Mechanism of endothelial cell NADPH oxidase activation by angiotensin: II. Role of the p47phox subunit. J Biol Chem 2003; 278:12094- 100.

169. Xiao L, Pimentel DR, Wang J, Singh K, Colucci WS, Sawyer DB. Role of reactive oxygen species and NADPH oxidase in $\alpha_{1}$-adrenoceptor signaling 
in adult rat cardiac myocytes. Am J Physiol Cell Physiol 2002; 282:C92634.

170. Duerrschmidt N, Wippich N, Goettsch W, Broemme HJ, Morawietz H. Endothelin-1 induces NADPH oxidase in human endothelial cells. Biochem Biophys Res Commun 2000; 269:713-7.

171. Nakamura K, Fushimi K, Kouchi H, Mihara K, Miyazaki M, Ohe T, et al. Inhibitory effects of antioxidants on neonatal rat cardiac myocyte hypertrophy induced by tumor necrosis factor-a and angiotensin II. Circulation 1998; 98:794- 9.

172. Li JM, Mullen AM, Yun S, Wientjes F, Brouns GY, Thrasher AJ, et al. Essential role of the NADPH oxidase subunit p47(phox) in endothelial cell superoxide production in response to phorbol ester and tumor necrosis factor- a. Circ Res 2002; 90:143 -50.

173. Landmesser U, Dikalov S, Price SR, McCann L, Fukai T, Holland SM, et al. Oxidation of tetrahydrobiopterin leads to uncoupling of endothelial cell nitric oxide synthase in hypertension. J Clin Invest 2003; 111:1201 - 9.

174. Laursen JB, Somers M, Kurz S, McCann L, Warnholtz A, Freeman BA, et al. Endothelial regulation of vasomotion in apoE-deficient mice: implications for interactions between peroxynitrite and tetrahydrobiopterin. Circulation 2001; 103:1282 -8.

175. McNally JS, Davis ME, Giddens DP, Saha A, Hwang J, Dikalov S, et al. Role of xanthine oxidoreductase and NADPH oxidase in endothelial superoxide 
production in response to oscillatory shear stress. Am J Physiol Heart Circ Physiol 2003; 285:H2290- 7.

176. Li JM, Shah AM. Endothelial cell superoxide generation: regulation and relevance for cardiovascular pathophysiology. Am J Physiol Regul Integr Comp Physiol 2004; 287:R1014- 30.

177. Lassegue B, Clempus RE. Vascular NADPH oxidases: specific features, expression, and regulation. Am J Physiol Regul Integr Comp Physiol 2003; 285:R277- 97.

178. Griendling KK, Sorescu D, Ushio-Fukai M. NADPH oxidase: role in cardiovascular biology and disease. Circ Res 2000; 86:494- 501.

179. Lambeth JD. NOX enzymes and the biology of reactive oxygen. Nat Rev Immunol 2004; 4:181 -9.

180. Geiszt M, Kopp JB, Varnai P, Leto TL. Identification of renox, an NADPH oxidase in kidney. Proc Natl Acad Sci U S A 2000; 97:8010-4.

181. Ambasta RK, Kumar P, Griendling KK, Schmidt HH, Busse R, Brandes RP. Direct interaction of the novel NOX proteins with p22phox is required for the formation of a functionally active NADPH oxidase. J Biol Chem 2004; 279:45935- 41.

182. Martyn KD, Frederick LM, von LK, Dinauer MC, Knaus UG. Functional analysis of NOX4 reveals unique characteristics compared to other NADPH oxidases. Cell Signal 2006; 18:69- 82. 
183. Van Buul JD, Fernandez-Borja M, Anthony EC, Hordijk PL. Expression and localization of NOX2 and NOX4 in primary human endothelial cells. Antioxid Redox Signal 2005; 7:308- 17.

184. Byrne JA, Grieve DJ, Bendall JK, Li JM, Gove C, Lambeth JD, et al. Contrasting roles of NADPH oxidase isoforms in pressure-overload versus angiotensin II-induced cardiac hypertrophy. Circ Res 2003; 93:802 - 5 .

185. Li JM, Gall NP, Grieve DJ, Chen M, Shah AM. Activation of NADPH oxidase during progression of cardiac hypertrophy to failure. Hypertension 2002; 40:477-84.

186. Colston JT, de la Rosa SD, Strader JR, Anderson MA, Freeman GL. $\mathrm{H}_{2} \mathrm{O}_{2}$ activates Nox4 through PLA2-dependent arachidonic acid production in adult cardiac fibroblasts. FEBS Lett 2005; 579:2533-40.

187. Pagano PJ, Clark JK, Cifuentes-Pagano ME, Clark SM, Callis GM, Quinn MT. Localization of a constitutively active, phagocyte-like NADPH oxidase in rabbit aortic adventitia: enhancement by angiotensin II. Proc Natl Acad Sci U S A 1997; 94:14483- 8.

188. Liu J, Ormsby A, Oja-Tebbe N, Pagano PJ. Gene transfer of NADPH oxidase inhibitor to the vascular adventitia attenuates medial smooth muscle hypertrophy. Circ Res 2004; 95:587-94.

189. Ago T, Kitazono T, Ooboshi H, lyama T, Han YH, Takada J, et al. Nox4 as the major catalytic component of an endothelial NADPH oxidase. Circulation 2004; 109(2):227 -33. 
190. Cucoranu I, Clempus R, Dikalova A, Phelan PJ, Ariyan S, Dikalov S, et al. NADPH oxidase 4 mediates transforming growth factor- $\beta$ 1-induced differentiation of cardiac fibroblasts into myofibroblasts. Circ Res 2005; 97:900-7.

191. Tsutsui H, Ide T, Kinugawa S. Mitochondrial oxidative stress, DNA damage, and heart failure. Antioxid Redox Signal. 2006; 8:1737-1744.

192. Matsushima S, Ide T, Yamato M, Matsusaka H, Hattori F, Ikeuchi M, Kubota T, Sunagawa K, Hasegawa Y, Kurihara T, Oikawa S, Kinugawa S, Tsutsui H. Overexpression of mitochondrial peroxiredoxin-3 prevents left ventricular remodeling and failure after myocardial infarction in mice. Circulation. 2006; $113: 1779-1786$.

193. Yao Z, Tong J, Tan X, Li C, Shao Z, Kim WC, Vanden Hoek TL, Becker LB, Head CA, Schumacker PT. Role of reactive oxygen species in acetylcholineinduced preconditioning in cardiomyocytes. Am J Physiol Heart Circ Physiol. 1999; 277:H2504-H2509.

194. Pain T, Yang XM, Critz SD, Yue Y, Nakano A, Liu GS, Heusch G, Cohen MV, Downey JM. Opening of mitochondrial $\mathrm{K}^{+}$(ATP) channels triggers the preconditioned state by generating free radicals. Circ Res. 2000; 87:460466.

195. Oldenburg O, Yang XM, Krieg T, Garlid KD, Cohen MV, Grover GJ, Downey JM. P1075 opens mitochondrial $\mathrm{K}^{+}$(ATP) channels and generates reactive 
oxygen species resulting in cardioprotection of rabbit hearts. J Mol Cell Cardiol. 2003; 35:1035-1042.

196. Oldenburg O, Qin Q, Krieg T, Yang XM, Philipp S, Critz SD, Cohen MV, Downey JM. Bradykinin induces mitochondrial ROS generation via NO, cGMP, PKG, and mitochondrial $\mathrm{K}^{+}$ATP channel opening and leads to cardioprotection. Am J Physiol Heart Circ Physiol. 2004; 286:H468-H476.

197. Xu Z, Ji X, Boysen PG. Exogenous nitric oxide generates ROS and induces cardioprotection: involvement of PKG, mitochondrial $\mathrm{K}^{+}$ATP channels, and ERK. Am J Physiol Heart Circ Physiol. 2004; 286: H1433-H1440.

198. Kimura S, Zhang GX, Nishiyama A., Shokoji T, Yao L, Fan YY, Rahman M, Suzuki T, Maeta H, Abe Y. Role of NADPH oxidase- and mitochondriaderived reactive oxygen species in cardioprotection of ischemic reperfusion injury by angiotensin II. Hypertension. 2005; 45: 860-866.

199. Andrukhiv A, Costa AD, West IC, Garlid KD 6. Opening mitochondrial $\mathrm{K}^{+}$ ATP increases superoxide generation from complex I of the electron transport chain. Am J Physiol Heart Circ Physiol. 2006; 291:H2067-H2074.

200. Xiao L, Pimental DR, Amin JK, Singh K, Sawyer DB, Colucci WS. MEK1/2ERK1/2 mediates a1-adrenergic receptor-stimulated hypertrophy in adult rat ventricular myocytes. J Mol Cell Cardiol 2001; 33:779-87.

201. Kuster GM, Pimentel DR, Adachi T, Ido Y, Brenner DA, Cohen RA, et al. \{alpha\}-Adrenergic receptor-stimulated hypertrophy in adult rat ventricular 
myocytes is mediated via thioredoxin-1-sensitive oxidative modification of thiols on Ras. Circulation 2005; 111:1192- 8.

202. Lassegue B, Sorescu D, Szocs K, Yin Q, Akers M, Zhang Y, et al. Novel gp91phox homologues in vascular smooth muscle cells: NOX1 mediates angiotensin II-induced superoxide formation and redox-sensitive signaling pathways. Circ Res 2001; 88:888-94.

203. Adachi T, Pimentel DR, Heibeck T, Hou X, Lee YJ, Jiang B, et al. SGlutathiolation of Ras mediates redox-sensitive signaling by angio-tensin II in vascular smooth muscle cells. J Biol Chem 2004; 279:29857-62.

204. Djordjevic T, Bel Aiba RS, Bonello S, Pfeilschifter J, Hess J, Gorlach A. Human urotensin II is a novel activator of NADPH oxidase in human pulmonary artery smooth muscle cells. Arterioscler Thromb Vasc Biol 2005; $25: 519-25$.

205. Gorin Y, Ricono JM, Kim NH, Bhandari B, Choudhury GG, Abboud HE. Nox4 mediates angiotensin II-induced activation of Akt/protein kinase B in mesangial cells. Am J Physiol Renal Physiol 2003; 285:F219- 29.

206. Herkert O, Diebold I, Brandes RP, Hess J, Busse R, Gorlach A. NADPH oxidase mediates tissue factor-dependent surface procoagulant activity by thrombin in human vascular smooth muscle cells. Circulation 2002; $105: 2030-6$. 
207. Sabri A, Hughie HH, Lucchesi PA. Regulation of hypertrophic and apoptotic signaling pathways by reactive oxygen species in cardiac myocytes. Antioxid Redox Signal. 2003; 5:731-740.

208. Wei S, Rothstein EC, Fliegel L, Dell'Italia LJ, Lucchesi PA. Differential MAP kinase activation and $\mathrm{Na}+/ \mathrm{H}+$ exchanger phosphorylation by $\mathrm{H}_{2} \mathrm{O}_{2}$ in rat cardiac myocytes. Am J Physiol Cell Physiol. 2001; 281:C1542-C1550.

209. Aikawa R, Nagai T, Tanaka M, Zou Y, Ishihara T, Takano H, Hasegawa H, Akazawa $\mathrm{H}$, Mizukami M, Nagai R, Komuro I. Reactive oxygen species in mechanical stress-induced cardiac hypertrophy. Biochem Biophys Res Commun. 2001; 289:901-907.

210. Kwon SH, Pimentel DR, Remondino A, Sawyer DB, Colucci WS. $\mathrm{H}_{2} \mathrm{O}_{2}$ regulates cardiac myocyte phenotype via concentration-dependent activation of distinct kinase pathways. J Mol Cell Cardiol. 2003; 35:615621.

211. Tanaka K, Honda M, Takabatake T. Redox regulation of MAPK pathways and cardiac hypertrophy in adult rat cardiac myocyte. J Am Coll Cardiol. $2001 ; 37: 676-685$.

212. Nakamura K, Fushimi K, Kouchi H, Mihara K, Miyazaki M, Ohe T, Namba M. Inhibitory effects of antioxidants on neonatal rat cardiac myocyte hypertrophy induced by tumor necrosis factor- $\alpha$ and angiotensin II. Circulation. 1998; 98:794-799. 
213. Delbosc S, Cristol JP, Descomps B, Mimran A, Jover B. Simvastatin prevents angiotensin II-induced cardiac alteration and oxidative stress. Hypertension. 2002; 40:142-147.

214. Amin JK, Xiao L, Pimental DR, Pagano PJ, Singh K, Sawyer DB, Colucci WS. Reactive oxygen species mediate a -adrenergic receptor-stimulated hypertrophy in adult rat ventricular myocytes. J Mol Cell Cardiol. 2001; 33:131-139.

215. Hirotani S, Otsu K, Nishida K, Higuchi Y, Morita T, Nakayama H, Yamaguchi O, Mano T, Matsumura Y, Ueno H, Tada M, Hori M. Involvement of nuclear factor-kB and apoptosis signal-regulating kinase 1 in G-protein-coupled receptor agonist-induced cardiomyocyte hypertrophy. Circulation. 2002; 105:509 -515.

216. Cesselli D, Jakoniuk I, Barlucchi L, Beltrami AP, Hintze TH, Nadal-Ginard B, Kajstura J, Leri A, Anversa P. Oxidative stress-mediated cardiac cell death is a major determinant of ventricular dysfunction and failure in dog dilated cardiomyopathy. Circ Res. 2001; 89:279 -286.

217. Yamaguchi O, Higuchi Y, Hirotani S, Kashiwase K, Nakayama H, Hikoso S, Takeda T, Watanabe T, Asahi M, Taniike M, Matsumura Y, Tsujimoto I, Hongo K, Kusakari Y, Kurihara S, Nishida K, Ichijo H, Hori M, Otsu K. Targeted deletion of apoptosis signal-regulating kinase 1 attenuates left ventricular remodeling. Proc Natl Acad Sci U S A. 2003; 100:15883-15888. 
218. Cheng TH, Cheng PY, Shih NL, Chen IB, Wang DL, Chen JJ. Involvement of reactive oxygen species in angiotensin II-induced endothelin-1 gene expression in rat cardiac fibroblasts. J Am Coll Cardiol. 2003; 42:18451854.

219. Spinale FG. Bioactive peptide signaling within the myocardial inter-stitium and the matrix metalloproteinases. Circ Res. 2002; 91:1082-1084.

220. Sorescu D, Griendling KK. Reactive oxygen species, mitochondria, and NADPH oxidases in the development and progression of heart failure. congest heart fail. 2002; 8:132-140.

221. Siwik DA, Pagano PJ, Colucci WS. Oxidative stress regulates collagen synthesis and matrix metalloproteinase activity in cardiac fibroblasts. Am J Physiol Cell Physiol. 2001; 280:C53-C60.

222. Siwik DA, Colucci WS. Regulation of matrix metalloproteinases by cytokines and reactive oxygen/nitrogen species in the myocardium. Heart Fail Rev. $2004 ; 9: 43-51.11363-11368$.

223. Ziczkwoski M, Davies JE, Ng LL. Sodium-hydrogen antiporter in normotensive Wistar Kyoto and spontaneously hypertensive rats. J Hypertens. 1994; 12:775-781.

224. Yoshida $\mathrm{H}$, Karmazyn $\mathrm{M}$. $\mathrm{Na}^{+} / \mathrm{H}^{+}$exchange inhibition attenuates hypertrophy and heart failure in 1-wk postinfarction rat myocardium. Am J Physiol Heart Circ Physiol. 2000; 278:H300-H304. 
225. Alvarez BV, Ennis IL, Camilión de Hurtado MC, Cingolani HE. Effects of antihypertensive therapy on cardiac sodium/hydrogen ion exchanger activity and hypertrophy in spontaneously hypertensive rats. Can J Cardiol. 2002; 18:667-672.

226. Karmazyn M, Liu Q, Gan XT, Brix BJ, Fliegel L. Aldosterone increases NHE1 expression and induces NHE-1-dependent hypertrophy in neonatal rat ventricular myocytes. Hypertension. 2003; 42:1171-1176.

227. Bak MI, Ingwall JS. Contribution of $\mathrm{Na}+/ \mathrm{H}+$ exchange to $\mathrm{Na}+$ overload in the ischemic hypertrophied hyperthyroid rat heart. Cardiovasc Res. 2003; $57: 1004-1014$

228. Chen L, Gan XT, Haist JV, Feng Q, Lu X, Chakrabarti S, Karmazyn M. Attenuation of compensatory right ventricular hypertrophy and heart failure following monocrotaline-induced pulmonary vascular injury by the $\mathrm{Na}+/ \mathrm{H}+$ exchange inhibitor cariporide. J Pharmacol Exp Ther. 2001; 298:469-476.

229. Baartscheer A, Schumacher CA, van Borren MM, Belterman CN, Coronel R, Opthof T, Fiolet JW. Chronic inhibition of $\mathrm{Na}+/ \mathrm{H}+$ exchanger attenuates cardiac hypertrophy and prevents cellular remodeling in heart failure. Cardiovasc Res. 2005; 65:83-92.

230. Chahine M, Bkaily G, Nader M, Al-Khoury J, Jacques D, Beier N, Scholz W. NHE-1-dependent intracellular sodium overload in hypertrophic hereditary cardiomyopathy: prevention by NHE-1 inhibitor. J Mol Cell Cardiol. 2005; $38: 571-582$. 
231. Hayasaki-Kajiwara Y, Kitano Y, Iwasaki T, Shimamura T, Naya N, Iwaki K, Nakajima $\mathrm{M}$. $\mathrm{Na}+$ influx via $\mathrm{Na}+/ \mathrm{H}+$ exchange activates protein kinase $\mathrm{C}$ isoenzymes $\delta$ and $\varepsilon$ in cultured neonatal rat cardiac myocytes. $J$ Mol Cell Cardiol. 1999; 31(8):1559-72.

232. Linck B, Qiu Z, He Z, Tong Q, Hilgemann DW, Philipson KD. Functional comparison of the three isoforms of the $\mathrm{Na}+/ \mathrm{Ca}^{+2}$ exchanger (NCX1, NCX2, NCX3). Am J Physiol. 1998; 274:C415-423.

233. Nicoll DA, Longoni S, Philipson KD. Molecular cloning and functional expression of the cardiac sarcolemmal $\mathrm{Na}+/ \mathrm{Ca}^{+2}$ exchanger. Science. 1990; 250(4980):562-565.

234. Cook O, Low W, Rahamimoff $\mathrm{H}$. Membrane topology of the rat brain Na+Ca2+ exchanger. Biochim Biophys Acta. 1998; 1371(1):40-52.

235. Koushik SV, Bundy J, Conway SJ. Na+/Ca ${ }^{+2}$ exchanger is initially expressed in a heart-restricted pattern within the early mouse embryo. Mech Dev. 1999; 88(1):119-122.

236. Moorman AF, Vermeulen JL, Koban MU, Schwartz K, Lamers WH, Boheler KR. Patterns of expression of sarcoplasmic reticulum $\mathrm{Ca}^{+2}$-ATPase and phospholamban mRNAs during rat heart development. Circ Res. 1995; 76(4):616-625.

237. Iwamoto T, Nakamura TY, Pan Y, Uehara A, Imanaga I, Shigekawa M. Unique topology of the internal repeats in the cardiac $\mathrm{Na}+/ \mathrm{Ca}^{+2}$ exchanger. FEBS Lett. 1999; 446(2-3):264-268. 
238. Nicoll DA, Ottolia M, Lu L, Lu Y, Philipson KD. A new topological model of the cardiac sarcolemmal $\mathrm{Na}+/ \mathrm{Ca}^{+2}$ exchanger. Biol Chem. 1999; 274(2):910-917.

239. Matsuoka S, Nicoll DA, Reilly RF, Hilgemann DW, Philipson KD. Initial localization of regulatory regions of the cardiac sarcolemmal $\mathrm{Na}+/ \mathrm{Ca}+2$ exchanger. Proc Natl Acad Sci U S A. 1993; 90(9):3870-3874.

240. Hilgemann DW. Giant excised cardiac sarcolemmal membrane patches: sodium and sodium-calcium exchange currents. Pflugers Arch. 1989; 415(2):247-249.

241. Satoh H, Ginsburg KS, Qing K, Terada H, Hayashi H, Bers DM. KB-R7943 block of $\mathrm{Ca}^{+2}$ influx via $\mathrm{Na}+/ \mathrm{Ca}^{+2}$ exchange does not alter twitches or glycoside inotropy but prevents $\mathrm{Ca}^{+2}$ overload in rat ventricular myocytes. Circulation. 2000; 101(12):1441-1446.

242. Litwin SE, Li J, Bridge $\mathrm{JH}$. $\mathrm{Na}+/ \mathrm{Ca}^{+2}$ exchange and the trigger for sarcoplasmic reticulum $\mathrm{Ca}^{+2}$ release: studies in adult rabbit ventricular myocytes. Biophys J. 1998; 75(1):359-371.

243. Sipido KR, Maes M, Van de Werf F. Low efficiency of Ca2+ entry through the $\mathrm{Na}+/ \mathrm{Ca}^{+2}$ exchanger as trigger for $\mathrm{Ca} 2+$ release from the sarcoplasmic reticulum. A comparison between L-type $\mathrm{Ca} 2+$ current and reverse-mode $\mathrm{Na}+/ \mathrm{Ca}^{+2}$ exchange. Circ Res. 1997; 81(6):1034-1044. 
244. Wasserstrom JA, Vites AM. The role of $\mathrm{Na}+/ \mathrm{Ca}^{+2}$ exchange in activation of excitation-contraction coupling in rat ventricular myocytes. J Physiol. 1996; 493 (2):529-542.

245. Bers DM, Christensen DM, Nguyen TX. Can Ca++ entry via $\mathrm{Na}+/ \mathrm{Ca}^{+2}$ exchange directly activate cardiac muscle contraction? J Mol Cell Cardiol. 1988; 20(5):405-414.

246. Yang HT, Sakurai K, Sugawara H, Watanabe T, Norota I, Endoh M. Role of $\mathrm{Na}+/ \mathrm{Ca}^{+2}$ exchange in endothelin-1-induced increases in $\mathrm{Ca} 2+$ transient and contractility in rabbit ventricular myocytes: pharmacological analysis with KB-R7943. Br J Pharmacol. 1999; 126(8):1785-1795.

247. Hasenfuss G. Alterations of calcium-regulatory proteins in heart failure. Cardiovasc Res. 1998; 37(2):279-289.

248. Mattiello JA, Margulies KB, Jeevanandam V, Houser SR. Contribution of reverse-mode $\mathrm{Na}+/ \mathrm{Ca}^{+2}$ exchange to contractions in failing human left ventricular myocytes. Cardiovasc Res. 1998; 37(2):424-431.

249. Tani M. Mechanisms of $\mathrm{Ca}^{+2}$ overload in reperfused ischemic myocardium. Annu Rev Physiol. 1990; 52:543-559.

250. Hilgemann DW, Collins A, Matsuoka S. Steady-state and dynamic properties of cardiac $\mathrm{Na}+/ \mathrm{Ca}^{+2}$ exchange. Secondary modulation by cytoplasmic calcium and ATP. J Gen Physiol. 1992; 100(6):933-961.

251. DiPolo R, Beauge L. Characterization of the reverse $\mathrm{Na}+/ \mathrm{Ca}^{+2}$ exchange in squid axons and its modulation by $\mathrm{Ca}^{+2} \mathrm{i}$ and $\mathrm{ATP}$. $\mathrm{Ca}^{+2} \mathrm{i}-\mathrm{dependent}$ 
$\mathrm{Na}+\mathrm{i} / \mathrm{Ca}^{+2} \mathrm{O}$ and $\mathrm{Na}^{+i} / \mathrm{Na}^{+} \mathrm{O}$ exchange modes. J Gen Physiol. 1987; $90(4): 505-525$

252. Matsuoka S, Nicoll DA, Hryshko LV, Levitsky DO, Weiss JN, Philipson KD. Regulation of the cardiac $\mathrm{Na}+/ \mathrm{Ca}^{+2}$ exchanger by $\mathrm{Ca}^{+2}$. Mutational analysis of the Ca+2 binding domain. J Gen Physiol. 1995; 105(3):403-420.

253. Levitsky DO, Nicoll DA, Philipson KD. Identification of the high affinity $\mathrm{Ca}^{+2}$

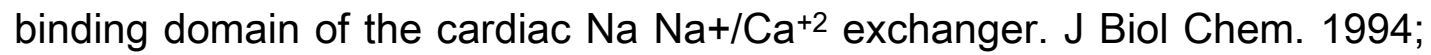
269(36):22847-22852.

254. Miura Y, Kimura J. Sodium-calcium exchange current Dependence on internal $\mathrm{Ca}$ and $\mathrm{Na}$ and competitive binding of external $\mathrm{Na}$ and $\mathrm{Ca}$. J Gen Physiol. 1989; 93:1129-1145.

255. Dyck C, Maxwell K, Buchko J, Trac M, Omelchenko A, Hnatowich M, Hryshko LV. Structure-function analysis of CALX1.1, a Na+/Ca+2 exchanger from Drosophila. Mutagenesis of ionic regulatory sites. J Biol Chem. 1998; 273(21):12981-12987.

256. Doering AE, Lederer WJ. The mechanism by which cytoplasmic protons inhibit the sodium-calcium exchanger in guinea-pig heart cells. J Physiol. $1993 ; 466: 481-499$.

257. Philipson KD, Bersohn MM, Nishimoto AY. Effects of $\mathrm{pH}$ on $\mathrm{Na}+/ \mathrm{Ca}^{+2}$ exchange in canine cardiac sarcolemmal vesicles. Circ Res. 1982; 50(2):287-293. 
258. He Z, Tong Q, Quednau BD, Philipson KD, Hilgemann DW. Cloning, expression, and characterization of the squid $\mathrm{Na}+/ \mathrm{Ca}^{+2}$ exchanger (NCXSQ1). J Gen Physiol. 1998; 111(6):857-873.

259. Hilgemann DW, Ball R. Regulation of cardiac $\mathrm{Na}+, \mathrm{Ca}^{+2}$ exchange and KATP potassium channels by PIP2. Science. 1996; 273(5277):956-959.

260. Reeves JP, Bailey CA, Hale CC. Redox modification of $\mathrm{Na}+/ \mathrm{Ca}^{+2}$ exchange activity in cardiac sarcolemmal vesicles. J Biol Chem. 1986; 261(11):49484955.

261. Santacruz-Toloza L, Ottolia M, Nicoll DA, Philipson KD. Functional analysis of a disulfide bond in the cardiac $\mathrm{Na}+/ \mathrm{Ca}^{+2}$ exchanger. $\mathrm{J}$ Biol Chem. 2000; 275(1):182-188.

262. Kusuoka H, Camilión de Hurtado MC, Marban E. Role of $\mathrm{Na}+/ \mathrm{Ca}^{+2}$ exchange in the mechanism of myocardial stunning: protective effect of reperfution with high sodium solution. JACC. 1993; 21(1):240-248.

263. Sei CA, Irons CE, Sprenkle AB, McDonough PM, Brown JH, Glembotski CC. The alpha-adrenergic stimulation of atrial natriuretic factor expression in cardiac myocytes requires calcium influx, protein kinase $\mathrm{C}$, and calmodulinregulated pathways. J Biol Chem. 1991; 266:15910-15916.

264. Sonnenberg H. Mechanism of release and renal tubular action of atrial natriuretic factor. Fed Proc. 1986; 45:2106-2110. 
265. LaPointe MC, Deschepper CF, Wu JP, Gardner DG. Extracellular calcium regulates expression of the gene for atrial natriuretic factor. Hypertension. 1990;15:20-28.

266. Crabtree GR. Generic signals and specific outcomes: signaling through $\mathrm{Ca}^{+2}$, calcineurin and NFAT. Cell. 1999; 96:611-614.

367. Klee CB, Ren H, Wang X. Regulation of the calmodulin-stimulated protein phosphatase, calcineurin. J Biol Chem. 1998; 2 73:13367-13370.

268. Dolmetsch RE, Lewis RS, Goodnow CC, Healy JI. Differential activation of transcription factors induced by $\mathrm{Ca}^{+2}$ response amplitude and duration. Nature. 1997; 386:855-858.

269. Hogan PG, Chen L, Nardone J, Rao A. Transcriptional regulation by clacium, calcineurin, and NFAT. Genes Dev. 2003; 17:2205-2232.

270 Zhang W, Kowal RC, Rusnak F, Sikkink RA, Olson EN, Victor RG. Failure of calcineurin inhibitors to prevent pressure-overload left ventricular hypertrophy in rats. Circ Res. 1999; 84:722-728.

271. Ding B, Price RL, Borg TK, Weinberg EO, Halloran PF, Lorell BH. Pressure overload induces severe hypertrophy in mice treated with cyclosporine, an inhibitor of calcineurin. Circ Res. 1999; 84:729-734.

272. Molkentin JD, Lu JR, Antos CL, Markham B, Richardson J, Robbins J, Grant SR, Olson EN. A calcineurin-dependent transcriptional pathway for cardiac hypertrophy. Cell. 1998; 93:215-228. 
273. Sakata Y, Masuyama T, Yamamoto K, Nishikawa N, Yamamoto H, Kondo H, Ono K, Otsu K, Kuzuya T, Miwa T, Takeda H, Miyamoto E, Hori M. Calcineurin inhibitor attenuates left ventricular hypertrophy, leading to prevention of heart failure in hypertensive rats. Circulation. 2000; 102:22692275.

274. Meguro T, Hong C, Asai K, Takagi G, McKinsey TA, Olson EN, Vatner SF. Cyclosporine attenuates pressure-overload hypertrophy in mice while enhancing susceptibility to decompensation and heart failure. Circ Res. 1999; 84:735-740.

275. Opie E, Bjornerheim R, Clausen OP, Attramadal H. Cyclosporin A inhibits cardiac hypertrophy and enhances cardiac dysfunction during postinfarction failure in rats. Am J Physiol Heart Circ Physiol. 2000; 278:H2115-H2123.

276. Nagata K, Somura F, Obata K, Odashima M, Izawa H, Ichihara S Nagasaka T, Iwase M, Yamada Y, Nakashima N, Yokota M. AT 1 receptor blockade reduces cardiac calcineurin activity in hypertensive rats. Hypertension. $2002 ; 40: 168-174$

277. Zou Y, Yamazaki T, Nakagawa K, Yamada H, Iriguchi N, Toko H, Takano H, Akazawa H, Nagai R, Komuro I. Continuous blockade of L-type $\mathrm{Ca}^{+2}$ channels suppresses activation of calcineurin and development of cardiac hypertrophy in spontaneously hypertensive rats. Hypertens Res. 2002; $25: 117-124$ 
278. Ennis IL, Garciarena CD, Escudero EM, Pérez NG, Dulce RA, Camilión de Hurtado MC, Cingolani HE. Normalization of the calcineurin pathway underlies the regression of hypertensive hypertrophy induced by $\mathrm{Na}+/ \mathrm{H}+$ exchanger-1 (NHE-1) inhibition. Can J Physiol Pharmacol. 2007; 85:301310.

279. Rothermel BA, McKinsey TA, Vega RB, Nicol RL, Mammen P, Yang J, Antos CL, Shelton JM, Bassel-Duby R, Olson EN, Williams RS. Myocyteenriched calcineurin-interacting protein, MCIP1, inhibits cardiac hypertrophy in vivo. Proc Natl Acad Sci USA. 98:3328-3333, 2001

280. Hill JA, Rothermel B, Yoo KD, Cabuay B, Demetroulis E, Weiss RM, Kutschke W, Bassel-Duby R, Williams RS. Targeted inhibition of calcineurin in pressure-overload cardiac hypertrophy. Preservation of systolic function. $\mathrm{J}$ Biol Chem. 277:10251-10255, 2002.

281. Bueno OF, Wilkins BJ, Tymitz KM, Glascock BJ, Kimball TF, Lorenz JN, Molkentin JD. Impaired cardiac hypertrophic response in calcineurin A $\beta$ deficient mice. Proc Natl Acad Sci USA. 2002; 99:4586-4591. 